UNIVERSIDADE DE SÃO PAULO

ESCOLA DE EDUCAÇÃO FÍSICA E ESPORTE

ENTRE O MITO E A HISTÓRIA:

GÊNESE E DESENVOLVIMENTO DAS MANIFESTAÇÕES ATLÉTICAS

NA GRÉCIA ANTIGA

Raoni Perrucci Toledo Machado

SÃO PAULO

2010 
ENTRE O MITO E A HISTÓRIA:

GÊNESE E DESENVOLVIMENTO DAS MANIFESTAÇÕES ATLÉTICAS NA GRÉCIA ANTIGA

\section{RAONI PERRUCCI TOLEDO MACHADO}

Tese apresentada à Escola de Educação Física e Esporte da Universidade de São Paulo, como requisito parcial para obtenção do grau de Doutor em Ciências. Programa: Educação Física. 
Machado, Raoni Perrucci Toledo

Entre o Mito e a História: gênese e desenvolvimento das manifestações atléticas na Grécia antiga / Raoni Perrucci Toledo Machado - SãoPaulo : [s.n.], 2010. $121 \mathrm{p}$.

Tese (Doutorado) - Escola de Educação Física e Esporte da Universidade de São Paulo.

Orientadora: Prof ${ }^{\mathrm{a}}$. Dr ${ }^{\mathrm{a}}$. Katia Rubio.

1. Mitologia 2. História 3. Jogos Olímpicos I. Título. 


\section{AGRADECIMENTOS}

Agradeço, primeiramente, aos meus pais, Paulo e Ana Catarina, que me educando com amor e dedicação, são também responsáveis por este trabalho;

Agradeço também à minha orientadora, Katia Rubio, por me guiar através do tortuoso caminho da mitologia;

À Academia Olímpica Brasileira e a Academia Olímpica Internacional, por terem me proporcionado a oportunidade de conhecer a Grécia, e poder ver, tocar e sentir um pouco da realidade dos antigos helenos;

Ao pessoal do departamento de pós-graduação, Ilza e Marcio, por fazer com que minha jornada fosse o mais segura possível;

Aos meus colegas do Centro de Estudos Sócio-Culturais que também contribuíram bastante para que eu não me perdesse do meu foco;

Ao Walter Correa e Rogério de Almeida, por me ajudarem bastante com a qualificação;

À professora Violeta Pereira, por toda a ajuda e encorajamento que me deu para estudar a cultura egípcia;

À CAPES, pelo auxilio financeiro;

E por fim, à Marina, minha musa, que sem ela inspiração não viria. 
SUMÁRIO

Página

LISTA DE SIGLAS, ABREVIAÇÕES E SÍMBOLOS 7

RESUMO 8

ABSTRACT

$\begin{array}{lr}\text { INTRODUÇÃO } & 10\end{array}$

2 OBJETIVO 16

3 MÉTODO 16

$4 \quad$ REVISÃO DA LITERATURA 17

4.1 Os Jogos Públicos 17

$\begin{array}{lll}\text { 4.1.1 As Práticas Atléticas } & 17\end{array}$

4.1.2 Os Jogos Pan-Helênicos 25

4.1.2.1 Jogos Olímpicos 25

4.1.2.2 Jogos Píticos 31

4.1.2.3 Jogos Nemeus 33

4.1.2.4 Jogos Ístmicos $\quad 35$

4.1.2.5 As Panatenaias 37

4.1.3 Poesia grega 38

4.1.4 A Poesia e os Jogos 53

4.1.5 Mitos e Deuses 58

4.2 Fundamentação Teórica e Recorte Histórico 60

4.2.1 A Cultura e os Símbolos $\quad 61$

$\begin{array}{lll}\text { 4.2.2 } & \text { A Construção do Matriarcado } & 73\end{array}$

4.2.3 A busca pelo Divino 76

4.2.4 A influência Indo-européia $\quad 81$ 
SUMÁRIO

Página

4.2.5 A influência Egípcia 94

5 CONSIDERAÇÕES FINAIS 109

REFERÊNCIAS 
LISTA DE SIGLAS, ABREVIAÇÕES E SÍMBOLOS

Hist. História (Heródoto)

Hist. História da Guerra do Peloponeso (Tucídides) 
RESUMO

\title{
ENTRE O MITO E A HISTÓRIA: GÊNESE E DESENVOLVIMENTO DAS MANIFESTAÇÕES ATLÉTICAS NA GRÉCIA ANTIGA
}

\author{
Autor: RAONI PERRUCCI TOLEDO MACHADO \\ Orientador: PROF ${ }^{\mathrm{a}}$. DR ${ }^{\mathrm{a}}$. KATIA RUBIO
}

Mesmo que seja impossível determinar as origens das práticas atléticas na Grécia antiga, podemos dizer que elas existiam e faziam parte do cotidiano daquele povo naquela época, como nos demonstram as obras de Homero. Por isso, os sacerdotes daqueles antigos rituais decidiram realizar uma competição atlética para determinar quem seria incumbido de concluir o cerimonial. Eles acreditavam que nada de importante acontecia sem a interferência dos deuses, portanto, os vencedores de cada competição venciam, porque assim estava determinado pelo seu destino, tornando-os heróis, e consequentemente, escolhido dos deuses. Por isso, as origens dos principais rituais eram atribuídas aos heróis mitológicos, cuja estrutura cosmogônica de Hesíodo os coloca a um nível superior de existência. Então, além de buscar a re-atualização do gesto sagrado realizado na origem, procurando dar continuidade ao mundo tal como eles o conheciam, os cerimoniais ao mesmo tempo re-atualizavam a ação dos heróis em um momento mítico, que se confundia com a realidade. Dessa maneira, os Jogos foram a materialização desta estrutura mitológica, tendo nos heróis a consolidação desta imagem, ao mesmo tempo em que proporcionava o caráter de humanidade que lhe rendeu toda sua grandiosidade.

Palavras-chave: Mitologia, História, Jogos Olímpicos. 


\begin{abstract}
BETWEEN MYTH AND HISTORY: GENESIS AND DEVELOPMENT OF THE ATHLETIC MANIFESTATIONS IN ANCIENT GREECE
\end{abstract}

\author{
Author: RAONI PERRUCCI TOLEDO MACHADO \\ Adviser: PROF ${ }^{\mathrm{a}}$. DR ${ }^{\mathrm{a}}$. KATIA RUBIO
}

Even that being impossible to determine the origins of the athletic practices in the ancient Greece, we can say that they exited and were part of the daily of that people at that time, as show us the Homer's poetry. Therefore, the priests of those ancient rituals had decided to make an athletic competition to determine who would be charged to conclude the ceremonial. They believed that nothing of important happened without the god's interference, therefore, the winners of each competition were successful, because thus were determined by its destination, becoming heroes, and consequently, chosen by the gods. Therefore, the origins of the main rituals were attributed to the mythological heroes, whose Hesiod's cosmogonic structure, place them in a superior level of existence. Then, beyond to search the reactualization of the sacred act realized at the origin, looking for to give continuity to the world as they knew the ceremonials at the same time re-actualize the heroes action at a mythical moment, that it confuse with the reality. In this way, the Games had been the materialization of that mythological structure, having in the heroes the consolidation of that image, at the same time that it provides the humanity character that relieved it all its greatness.

Keywords: Mythology, History, Olympic Games. 


\section{INTRODUÇÃO}

O esporte moderno, assim como tantos outros aspectos do que podemos entender como "mundo ocidental", possui profundamente enterradas em suas estruturas raízes da antiga civilização helênica, sendo de alguma forma uma espécie de desdobramento do que eles iniciaram há cerca de dois mil e quinhentos anos antes.

Logicamente, não somente no que se refere ao "esporte", como também as manifestações culturais, religiosas, artísticas, etc. tanto do mundo antigo como do moderno, não se deram da mesma forma, cada uma delas foi influenciada por características únicas da sociedade a qual está inserida. Carl DIEN (1966), em sua clássica obra "A história dos Esportes", diz em relação a isso que "cada época da humanidade tem o seu esporte, e a essência de cada povo se reflete nele" (p. 9), se tornando impossível, por este motivo, qualquer tentativa de comparação direta entre o que vemos hoje, com aquilo que os helenos viam. Mesmo que os eventos atléticos tenham sido, em muitos casos, exatamente os mesmos (GAUQUELIN, LECLERCQ e SILVAN, 1995).

O que entendemos por "esporte" no mundo contemporâneo teve sua gênese em finais do século XVIII e inicio do XIX da era moderna, quando começou a se dar o renascimento das práticas atléticas, principalmente associadas a sua inclusão nas Public Schools da Inglaterra, fato reforçado pelos primeiros resultados das escavações que se iniciavam no local onde possivelmente estariam soterradas as ruínas do antigo santuário sagrado de Olímpia, palco de uma das maiores manifestações sócio-culturais de todos os tempos. Isso fez com que aquelas histórias da antiguidade deixassem de ser apenas obras da imaginação para se transformar em algo mais palpável, mais funcional. 
Apesar de já haverem nesta época tentativas para o seu renascimento, foi justamente esse o impulso que o fenômeno esportivo precisava para reacordar de seu sono milenar.

Mas afinal, o que teria acontecido, mais precisamente na Grécia antiga, de tamanha significação a aponto de influenciar as vidas de muitas gerações por aproximadamente um milênio?

Lá, de forma geral, as práticas atléticas eram um meio de formação do indivíduo em sua totalidade, podendo ser tratada de forma militar, medicinal e, sobretudo, pedagógica. Os grandes Jogos $^{1}$ públicos eram, em sua essência, festivais religiosos que movimentavam todo o território helênico, onde o homem buscava transcender sua condição de humano, aproximando-se dos deuses.

Isso sempre me chamou à atenção. No entanto, como poderia contribuir para esse campo de estudo, se o que aconteceu, de fato, naquela época, já está muito bem, e suficientemente documentado, como por exemplo, na obra já citada de Carl Dien, além dos grandes estudos de DURANTEZ (1979) e MUNGUIA (1992)?

Quando me matriculei, ainda como aluno especial, antes do ingresso regular no programa de mestrado da Escola de Educação Física e Esporte da Universidade de São Paulo, na disciplina denominada "Imaginário esportivo e cultura contemporânea", ministrada pela Profa. Dra. Kátia Rubio (que seria minha futura orientadora), pude visualizar que aquilo poderia ser estudado de outra maneira, seguindo um outro enfoque, não apenas o de caráter arqueológico.

A minha pergunta, no entanto, persistia. O que havia, afinal, por trás de tudo aquilo que justificasse sua grandeza, atestada pelas construções que até

\footnotetext{
${ }^{1}$ Utilizarei a palavra "Jogos" com sua inicial maiúscula sempre que estiver me referindo aos eventos atléticoreligiosos.
} 
hoje de alguma forma sobrevivem, além do enorme prestigio atribuído aos vencedores, como nos contam as histórias dos poetas?

Fui, então, encontrando as minhas primeiras pistas. FERREIRA SANTOS (2004c) afirma que as expressões corporais, caso dos antigos Jogos helênicos, são elementos de uma cultura imaterial. Portanto, para compreender os motivos que levaram à grandiosidade dos Jogos Públicos da Grécia Antiga, é preciso primeiro buscar o que havia por detrás daquela sociedade que os legitimava.

A resposta poderia, então, estar na associação entre a mitologia e todo o processo histórico que se desenvolveu adjacente a ela, atribuindo-lhe sentido e significado. Durante a minha pesquisa de mestrado (MACHADO, 2006), fiz uma espécie de descrição deste quadro, busquei apontar onde estava a zona de intersecção entre a realidade e a mitologia que resultava na grandeza destes eventos. Porém, percebi que não bastava apenas estudar a mitologia grega, era necessário também compreender os processos de como ela chegou a essa forma, desde as primeiras levas de invasores Indo-europeus na Grécia continental, assim como das ainda não claras influências egípcias que se davam em Creta, onde se desenvolveu a civilização minóica, de fundamental importância para a formação da antiga civilização helênica.

Foi com esse intuito que se desenvolveu esta pesquisa, procurando ir mais a fundo na compreensão sobre a formação e construção destes elementos mitológicos. Primeiramente realizei uma breve busca na pré-história para acompanhar o desenvolvimento da espécie Homo, associando sua evolução com uma discussão sobre cultura e imaginário para melhor compreender a formação e transmissão de símbolos como forma de linguagem, o que me levou a estudar as representações rupestres, as construções de estatuetas femininas até o seu 
desenvolvimento em diversas formas de cultos a deusas da fertilidade, me fazendo voltar mais uma vez à mitologia.

Os trabalhos de Junito Brandão sobre a mitologia grega, assim como as obras de Campbell em relação ao desenvolvimento da mitologia em geral, me ajudaram de forma substancial para o domínio deste conteúdo, que posteriormente foi associado à literatura grega propriamente dita, como as épicas poesias de Homero e Hesíodo, assim como os textos históricos de Heródoto e Tucídides.

Durante a realização do mestrado (MACHADO, 2006, p. 10), pude observar que:

Independentemente de qualquer período histórico, as características fundamentais do esporte são as mesmas, por mais distintas que sejam as manifestações socioculturais de seu tempo. Ele não faz parte de um tempo histórico, mas sim da multiplicidade das histórias regionais, de forma que a transição dos valores esportivos está muito mais associada à forma como a sociedade vê o mundo do que com as próprias mudanças de suas características.

Durante os anos de domínio macedônio sobre a Grécia, por exemplo, durante o século III a.C., não vemos nos registros de vitórias dos Jogos Olímpicos vencedores das grandes cidades do século $\mathrm{V}$ a.C., mas sim de pequenas cidades da região de Olímpia. Isso pode ser um indicio de uma grande queda no interesse dos gregos pelas atividades atléticas, ao menos as de caráter transcendente, que encontrou seu fim com o posterior domínio romano. Ou seja, os Jogos tendem a continuar acontecendo se eles se adaptarem as mudanças que ocorrerem no mundo a sua volta, sendo impossível sua continuidade quando ele não tiver representatividade para a comunidade em que está inserido, como foi o caso de sua extinção no mundo antigo, quando ele não mais se adaptou a 
mudança do "paganismo" para o cristianismo (SCHAUS e WENN, 2003). No mundo moderno, a lenta inclusão e aceitação do profissionalismo pelo "Movimento Olímpico" é um bom indicativo de que essa adaptação está sendo feita.

Deste modo, segundo RUBIO (2001), se vemos hoje os atletas de alto nível como uma representação do herói mitológico, como descrito por Campbell em "O Herói de mil faces", o mesmo poderia ser visto na Grécia Antiga, aparecendo primeiramente associado ao nobre guerreiro que se destacava no campo de batalha, como podemos ver nas epopeias de Homero, e depois colocado como uma forma diferenciada de humanidade por Hesíodo, em " $O$ trabalho e os dias". Quando associamos as próprias características colocadas por este poeta aos heróis, como sendo semideuses, a meio caminho do humano com o divino, pela forma em que eram encarados os eventos atléticos em seu caráter agonístico, fazemos com que nos Jogos se encontrem as condições ideais para a sua manifestação.

Diante disso, a busca pela construção da mitologia na sociedade grega da Antiguidade se tornou meu principal foco de pesquisa, para, depois de cumprida esta etapa, poder observar como se deu a influência delas para a transformação dos antigos cultos às forças obscuras da natureza nos grandes Jogos Públicos com tamanha representatividade para a sociedade grega.

HUIZINGA (1955, p. 35) em sua obra "Homo Ludens", se indagou a respeito de "como transcorreu o processo que começa como uma experiência cósmica, termina como uma representação lúdica desse ato?’.

A mesma pergunta pode ser aplicada para a realidade helênica da Antiguidade, e a que de certa forma estamos tentando responder.

Foi assim que nasceu "Entre o Mito e a História", muito embora eu reconheça que não foi uma ideia original, dado que o historiador helênico 
Dionísio de HALICARNASSO (1984) tenha se proposto a escrever sua grande obra "História antiga de Roma", em cerca de 30 a.C., partindo "Desde as mais antigas lendas, que os historiadores que me precederam omitiram, por serem difíceis de interpretar sem um grande estudo" $(1,8,1)$, indo até o começo da primeira guerra púnica, que teve seu inicio em 264 a.C., ou nas palavras do historiador, "no terceiro ano das CXXVIII Olimpíada".

Enquanto Dionísio se preocupou em contar a história antiga de Roma, retrocedendo até o ponto em que os acontecimentos da "vida real" se confundiam com os mitos, procurarei aqui ver como, entre o mito e a história, os dois puderam caminhar juntos por um período de tempo, sendo esta fase a de maior valor e significado para a grandiosidade dos eventos atlético-religiosos que viriam a ocorrer.

E por fim, parafraseando SCHAUS e WENN (2003, p. 24),

Os Jogos Olímpicos inspiraram os antigos jovens gregos a trabalhar duro, para buscar a glória em honra a sua família, sua cidade e seus deuses. Que ideais mais elevados os Jogos modernos podem inspirar os nossos jovens a buscar em seu cotidiano, em sua educação ou em seu desenvolvimento esportivo? Não apenas nos jovens, claro, mas também em nós mesmos, em cada um de nós, podemos ser guiados pelos ideais promovidos pelo Movimento Olímpico. Vemos aqui algo de como a história pode nos fazer mais conscientes, mesmo que deixemos a definição destes ideais para outros. 


\section{OBJETIVOS}

O objetivo deste estudo é identificar como os antigos rituais às forças da natureza se transformaram em práticas atléticas em honra aos deuses ou heróis e, posteriormente, se desenvolveram como os grandes Jogos Públicos na Grécia Antiga.

3 MÉTODO

Para tanto, será seguido o método de "pesquisa histórica analítica", conforme descrito por THOMAS e NELSON (2002), recorrendo a fontes relacionadas à literatura, à filosofia, à história antiga e, especificamente, à história dos Jogos Públicos na Grécia antiga. Será também utilizada a mitohermenêutica, termo desenvolvido por FERREIRA SANTOS (2004b), para realizar o diálogo entre os mitos e a historiografia descritiva, "buscando o sentido da existência humana nas obras da cultura e das artes, através dos símbolos e imagens organizadas em suas narrativas" (p. 144). 


\section{REVISÃO DE LITERATURA}

\subsection{Os Jogos Públicos}

\subsubsection{As Práticas Atléticas}

$\mathrm{Na}$ antiga civilização helênica, a prática das atividades atléticas era tida como um meio de desenvolvimento corporal de suma importância, fazia parte da Paidéia, ou seja, da formação completa do cidadão, assim como as aulas de musica, poesia e ética, por exemplo. Além disso, não só os gregos, mas grande parte das civilizações da antiguidade, acreditavam que poderiam, através do desenvolvimento de exercícios físicos, também desenvolver homens fortes capazes de defender suas cidades. A máxima expressão das práticas atléticas acontecia nos grandes Jogos Públicos, nos quais os atletas levavam consigo, além do seu próprio nome, o nome de seu pai, e o da cidade da qual era proveniente.

Segundo GODOY (1996), foi nas ilhas Cíclades, a leste da Península do Peloponeso, e especialmente em Creta que surgiram as primeiras evidências de práticas atléticas na Grécia Antiga, que provavelmente teriam sofrido influência egípcia para seu inicio e desenvolvimento.

As obras de Homero descrevem eventos "esportivos" com relativa precisão, como os jogos em honra a Pátroclo, após a morte deste em Ílion durante a guerra contra Tróia, com detalhes das competições de corrida de carro, pugilismo, luta, corrida pedestre, combate armado, lançamento de disco e dardo, e tiro com arco (Ilíada, canto XXIII). Além disso, há passagens como a diversão do exército de Aquiles na praia lançando disco e dardo, ou mais tarde, sobre os eventos dos Feácios para distrair Ulisses, nos quais competiram em corrida 
pedestre, luta, corrida de carro, lançamento de disco e pugilato (Odisséia, canto VIII, v. 112-1132 ), com Laodamas dizendo a Ulisses:

Quadram-te à maravilha: é do homem timbre De pés e mãos valer-se denodado.

E será justamente em Homero que encontraremos pela primeira vez a essência do esporte - o desejo de ser o melhor e de superar os outros homens, e o simples prazer pelo esforço. Todo soldado grego era também um atleta. Muitos autores datam os poemas homéricos de não antes do século IX a.C., é certo que aquela sociedade descrita existia já desde dois ou três séculos antes, não sendo gregos nativos, mas imigrantes vindo do norte. Era uma sociedade governada por uma aristocracia hereditária, que tinha uma organização do poder determinada pela virtude militar, armamentos e força física. Em meio a este contexto, podemos ver pela primeira vez a aparição da palavra "atleta" vindo justamente de Homero, aplicando-a precisamente contra Ulisses na mesma terra dos Feácios (Odisséia, canto VIII, v. 123-124), quando Euríalo, logo após o herói se recusar a participar dos eventos atléticos, dizer a ele que:

\section{Menos atleta válido pareces}

Que de marujos traficante mestre.

Esta frase foi bastante ofensiva para o herói, nos mostrando a significação do fato de "ser atleta" para aquela sociedade (GARDINER, 1971).

Em Homero, não temos nenhuma pista de que os Jogos exclusivamente fariam parte de cerimoniais religiosos, estando presentes em atividades do cotidiano, onde qualquer tipo de ocasião especial era suficiente

\footnotetext{
${ }^{2}$ Tradução de Odorico MENDES (2000).
} 
para a sua realização. HEGEL $^{3}$, citado por NAGEL (2006), diz que a Ilíada nos apresenta um conjunto de acontecimentos, que embora não totalmente contínuos, expressa a consciência de uma época. Por isso, pela forma como Homero descreve os eventos atléticos, ele já devia tê-lo visto muitas vezes antes, sabendo exatamente do que estava falando, mostrando que a sua inclusão nos poemas se deva a tradição e antiguidade destas práticas.

Antiguidade e tradição que antecedem a própria cultura helênica. Evidências apontam que a luta armada teria surgido como influência dos rituais fúnebres dos etruscos, que teriam se estabelecido na Península Itálica por volta do século XII a.C.. Já o lançamento do disco, inevitavelmente nos remete ao implemento que conhecemos, porém, em grego, a palavra "diskos" se refere a algo para se lançar, podendo ser qualquer objeto conveniente usado para tal, e como lançar pedras era um artifício útil em batalhas, a competição de lançamento era um bom teste de força e habilidade neste quesito. $\mathrm{O}$ arco e flecha era uma atividade não aristocrática, era uma arma de um soldado comum, talvez por isso sua utilização pode ser vista mais na Odisséia do que na Ilíada. Sua característica, como podemos ver em um diálogo na obra Héracles, de Eurípides $^{4}$ (FRANCISCATO, 2003), não permite diferenciar o homem valente do covarde e, talvez por isso, nunca tenha entrado no programa dos grandes Jogos Pan-helênicos. O salto em distancia com halteres, segundo LEE (2003), permanece com uma incógnita de como seria a sua execução, já que não temos uma descrição de sua realização completa, apenas das distâncias alcançadas e de que era precedido por uma curta corrida.

Podemos ver, então, em Homero, a verdadeira essência das práticas atléticas pelo simples prazer de sua prática. Elas tinham características aristocráticas, informais e espontâneas.

\footnotetext{
${ }^{3}$ HEGEL, G. W. F. Estética. Lisboa: Guimarães Editores, 1993.

${ }^{4}$ Hèracles, v. 153-164.
} 
Em relação a isso, CABRAL (2004b), diz que na Ilíada os jogos apenas faziam parte de cerimoniais fúnebres, enquanto na Odisséia eles eram parte de entretenimento. Em outras histórias, eles aparecem de formas semelhantes, como no mito dos Argonautas, onde uma prova de saltos é organizada em Lemnos como parte de um ritual fúnebre. Vemos também nesta mesma história uma luta de pugilato na tribo dos Bébrices e a invenção do Pentatlo por Jasão, a fim de premiar seu amigo Peleu como o atleta mais perfeito, que sempre chegava em segundo lugar. O lançamento do disco também é citado na mitologia, onde temos o exemplo de Apolo, que em uma disputa, acaba acertando e matando, sem querer, Jacinto, seu melhor amigo.

Mas não só em Homero podemos observar essa tendência de incluir jogos atléticos em memória a heróis. Mesmo em um período posterior, segundo VERNANT e VIDAL-NAQUET (2008), os gregos ainda colocavam o culto aos heróis em uma posição privilegiada da religião cívica, como claramente nos demonstra TUCÍDIDES (2001), que teria vivido ao menos três séculos depois do poeta, escrevendo que após a morte de um dos lideres espartanos, Brásidas, durante a grande Guerra do Peloponeso, ocorrida durante o século V a.C.,

(...) Foi construída uma balaustrada em volta de seu túmulo, e desde então depositam junto a ele oferendas a Brásidas como a um herói, e o honram com jogos atléticos e sacrifícios anuais (Hist. 5, 11).

Da mesma forma HERÓDOTO (2001), expõe um caso em que para uma maldição não continuar ocorrendo,

A pitonisa ordenou-lhes realizar suntuosas cerimônias fúnebres às suas vitimas e instituir em sua honra jogos gímnicos e corridas de carro (Hist. 1, 167). 
Isso se dava, pois as imagens simbólicas geralmente se remetem a um acontecimento especifico em seu dado momento histórico, e por este motivo, precisam constantemente ser revividas. Temos aqui o exemplo do herói mítico, um individuo que se sobressai em sua sociedade, sendo comum a sua associação a algum ritual depois de sua morte. Por ter essa posição de destaque, eram estabelecidos cultos em sua homenagem, pois para os gregos, a morte era uma perda de memória, e com isso, um morto sem culto era um morto anônimo. Os jogos fúnebres surgiram tendo este objetivo, eram realizados em honra aos que morreram, para que os vivos não perdessem a memória dos que se foram, e inclusive, não perdessem a memória de si próprios. Os competidores eram partes intrínsecas dos rituais, que se tratavam de uma exaltação às virtudes heróicas do falecido, especialmente a sua areté e a sua timé, cuja importância e significado veremos mais adiante (ALVARENGA, 2009).

A origem dos Jogos remonta à época do reinado de Cronos, onde se homenageavam as divindades em troca de proteção. Com o passar do tempo, alguns jogos ganharam tamanha importância que, se haviam guerras, estas eram interrompidas até o término das competições, sendo denominado este período de Ekekeiria, que significa "Trégua Sagrada". Era considerada uma falta bastante grave o não respeito dela, como, por exemplo, o ocorrido nos Jogos da $90^{\mathrm{a}}$ Olimpíada, em 420 a.C., nos quais os espartanos não puderam participar dos eventos porque foram considerados culpados da invasão à Lêpreon durante o período de trégua, e como se recusaram a pagar a multa estipulada de 2 minas por cada Hoplita ${ }^{5}$ invasor, além de pedir desculpas públicas, não tiveram sua inscrição aceita, acatando com respeito a decisão dos organizadores. Muito embora tenha havido um clima de tensão pela perspectiva de uma possível

\footnotetext{
${ }^{5}$ Um hoplita era o soldado que combatia em formação armada dos exércitos helênicos da antiguidade.
} 
revolta lacedemônica ${ }^{6}$, esta felizmente não ocorreu (TUCÍDIDES, 2001, Hist. 5, 49-50).

Na mesma obra, vemos uma reclamação do exército tebano, onde dizem que "eles tentaram apoderar-se de nossa cidade em tempos de paz, e o que é pior, em período de festas religiosas" (Hist. 3, 56). A trégua existia nos quatro principais Jogos Pan-helênicos: Olímpicos, Píticos, Ístmicos e Nemeus, porém, muitas vezes, ela poderia ser usada de outras maneiras, como, por exemplo, para poder visitar livremente o inimigo e conhecer seus planos para a guerra em andamento, como fizeram certa vez os atenienses em virtude dos Jogos Ístmicos (Hist. 8, 10).

Inicialmente, as práticas atléticas faziam parte de rituais religiosos onde o homem buscava transcender sua condição de humano e tentava aproximar-se dos deuses, e a maneira encontrada para isso naquela sociedade eram as demonstrações de destreza física, nas quais as vitórias eram entendidas como produto direto das escolhas divinas.

Os Jogos públicos, segundo SCHAUS e WENN (2003), devem ter sido realizados durante a Idade do Bronze na região do Mar Egeu por pelo menos meio milênio antes da instituição da regularidade dos Jogos Olímpicos em 776 a.C.. Nesses antigos eventos, a juventude aristocrata demonstrava sua força de maneira similar ao que viria a ocorrer posteriormente nos grandes festivais. Mesmo que haja uma dificuldade em demonstrar uma clara conexão entre a Idade do Bronze e o começo da Idade de Ferro, não podemos desconsiderar a possibilidade de realmente ter ocorrido esse tipo de herança cultural.

GARDINER (1971), no entanto, não acredita que exista conexão direta entre a origem dos grandes festivais e a instituição dos Jogos, se tratando de

\footnotetext{
${ }^{6}$ Lacedemônios eram os habitantes da região da Lecedemônia, onde se localizava a cidade de Esparta.
} 
duas coisas com características distintas. Os Jogos tiveram origem em diversas regiões, cada qual com características especificas de sua sociedade. Pausânias, citado pelo mesmo autor, de certa forma atesta a hipótese de Schaus e Wenn, afirmando que provavelmente eles foram realizados antes da "Idade das Trevas", mas foram esquecidos durante este período, sendo revividos um por um conforme iam sendo relembrados.

Na Antiguidade, segundo QUEVAL (2004), as práticas atléticas eram um meio de formação do indivíduo e podiam ser tratadas sob cunho militar, pedagógico ou medicinal. Na Grécia, além de preparar os cidadãos para se tornarem soldados capazes de defender seu território, o desenvolvimento corporal fazia parte da Paidéia, sendo tratado como importante ferramenta educativa, pois acreditava-se que isso levaria o homem a explorar seu potencial na relação corpo-alma e em relação à natureza. A inclusão da categoria para jovens nos principais Jogos a partir do século VI $a . C$., juntamente com o rápido aparecimento de muitos eventos atléticos por toda a Grécia, assim como a formação definida dos quatro Jogos Pan-Helênicos, são claras evidência de que as práticas atléticas eram uma parte essencial da educação do jovem cidadão grego.

Os grandes jogos revelavam o indivíduo em sua totalidade, tanto em relação à força física quanto em sua grandeza moral. Aqueles eventos eram grandes festivais religiosos que movimentavam toda a cultura helênica, e era a partir desta perspectiva que se justificava a glória da recompensa, assim como a violência vista nas lutas.

Uma das mais marcantes características dos Jogos helênicos foi a sua continuidade, se devendo principalmente ao que GARDINER (1971) chama de “conservadorismo religioso". Para o homem grego do século VIII $a$.C. eles eram mais do que apenas recreação, como aparece em Homero. No inicio o individuo 
competia quase que exclusivamente pela sua transcendência, mas depois passou a também competir por sua cidade. Foi inclusive a estrutura da cidade-estado que permitiu os festivais nacionais acontecerem, se tornando grandes competições inter cidades-estados. Ao mesmo tempo em que existia uma grande ênfase na vitória, tanto nos Jogos como no campo de batalha, essas competições foram responsáveis pela criação de um sentimento de unidade pan-helênica, e serviram como palco para a resolução de muitos entraves políticos (SCHAUS e WENN, 2003; FINLEY, 1983). A escolha deles como referência para estes assuntos mostra sua relevância para os povos da Antiguidade.

Isso se deu, pois na Grécia continental, onde a disputa territorial era bastante intensa, uma das principais formas que os gregos encontraram para demarcar seus territórios, quando as cidades ainda estavam em formação, foi, segundo POLIGNAC (1984), através de santuários localizados nos limites de sua área. Estes tinham como principal função religiosa os cultos para o florescimento daquela cidade, por meio de rituais às forças da natureza, através da associação entre a fertilidade natural com a fecundidade humana e, além disso, possuía também o motivo político de estabelecer os limites de seus territórios. Foi, portanto, das consequências do estabelecimento em aldeias que resultou na valorização religiosa do espaço, pois, segundo ELIADE (1983b), os indo-europeus inicialmente não tinham o costume de construir santuários.

A cidade surge, portanto, não somente baseada no desenvolvimento de uma comunidade, mas essencialmente quando um culto é organizado, fazendo com que exista um limite para a sua área, cuja consequência direta é fazer com que os habitantes daquela região se sintam pertencentes ao mesmo grupo social, tendo como fato determinante as crenças nos mesmos deuses, personificados pelos cultos públicos. Isso vem de acordo com as ideias do pioneiro trabalho de COULANGES (1961), "A Cidade antiga", descrevendo a Polis como uma 
comunidade, porém, entendendo a religião como o aspecto central da vida coletiva e determinante para sua identidade.

Os cerimoniais, no início, eram predominantemente cultos à Gaia, a deusa Terra, e somente mais tarde passaram a homenagear os diversos deuses locais. Não se sabem suas origens ao certo, mas, segundo MENARD (1991a), estavam carregadam de valores mitológicos transmitidos em forma de linguagem poética, que nutriam a imaginação de nossos ancestrais em relação aos fenômenos da natureza.

\subsubsection{Os Jogos Pan-Helênicos}

Existia, na Grécia antiga, quatro principais jogos que movimentavam toda aquela sociedade, por isso denominados Jogos Pan-helênicos. Eram eles os Jogos Olímpicos, realizados na antiga Olímpia, os Jogos Píticos, disputados em

Delfos, os Jogos Ístmicos que tinham lugar em Corinto, e os Jogos Nemeus, que eram realizados em Neméia. Cada um deles era carregado de histórias e significações próprias, cujas características poderemos ver a seguir.

\subsubsection{Jogos Olímpicos}

Os Jogos Olímpicos, o mais grandioso evento daquela época, era realizado em Olímpia, um santuário sagrado localizado a oeste da Península do Peloponeso, às margens do Rio Alfeu. Por cerca de 12 séculos foi referência de todos os tipos de desejos e aspirações de qualquer cidadão helênico, levava uma multidão de todos os cantos da Grécia para assistir às disputas. No início, os rituais a Zeus que lá se realizavam eram concluídos com o acendimento de uma pira em sua homenagem, e teria a honra de acendê-la apenas alguém especial, 
nomeado pelos deuses. Para isso, de acordo com DURANTEZ (1979) e corroborado por DIEN (1966), os antigos sacerdotes organizaram uma corrida de curta distância, tendo o vencedor - cujo destino estava selado pelos deuses, através de sua velocidade, símbolo da juventude - a incumbência de concluir o cerimonial, colocando um novo fogo que não se apagaria até o ritual seguinte, representação da eterna juventude.

De acordo com as histórias da mitologia, o início dos Jogos Olímpicos se deu por Pélope, filho de Tântalo, Rei de Fígia, para homenagear e agradecer sua vitória sobre Enômao, Rei de Pisa, em uma corrida de carro por disputa de sua filha, Hipodâmia. Conta-se que sua vitória ocorreu porque certa vez o pai de Pélope o fez em pedaços e o serviu aos deuses em uma refeição. Depois de descoberto e tendo sido refeito, foi "adotado" por Poseidon, o qual the enviou um carro de ouro e cavalos alados que jamais se cansavam, tornando certa a sua vitória. Por outro lado, OTTO (2005) diz que Pélope teria subornado o cocheiro real, Mirtilo, que era filho de Hermes, o deus dos ladrões e das trapaças, para afrouxar as rédeas do carro de Enômao, que se soltou durante a corrida, causando sua morte. Ou que simplesmente vendo que seria derrotado, se atirou do carro, matando-se. Pélope, então, organizou os Jogos Olímpicos e sua mulher, Hipodâmia, os Jogos Heranos, agradecendo Zeus e Hera por este feito. No santuário de Olímpia, ainda hoje se podem ver as ruínas do Pelopión e do Hidodamión, locais onde estariam enterrados seus corpos (DURANTEZ, 1979; MUNGUIA, 1992).

Em relação a isso, dando maior autenticidade a esta história, CABRAL (2004b) diz que existem evidências de um culto a Pélope e a Hipodâmia, consistido de uma base circular feita de pedra cercada de estatuetas de cavalos e de aurigas, datando de aproximadamente 2.000 a.C., mostrando que o culto é muito mais antigo do que sua origem atribuída, devendo, segundo DIEN (1966), 
ter sido batizados de "Olímpicos" somente depois de ter sua realização associada a Zeus, em referência a localização mitológica de seu trono, no Monte Olimpo, uma montanha de aproximadamente 3.000 metros de altura situada na região da Bahia de Salônica.

Existe ainda, de acordo com GAUQUELIN et alli (1995), uma outra versão, protagonizada por Héracles. O quinto de seus doze trabalhos consista em limpar os estábulos de Augias, local onde viviam três mil bois, e que não eram limpos já fazia trinta anos, cujo odor causava a esterilidade de todo o solo de Elida. Por o herói ter desviado parte do curso do Rio Alfeu para passar por dentro dos estábulos, e assim efetuar sua limpeza, o Rei não considerou o trabalho como tendo sido feito por Héracles, e sim pelo rio, não cumprindo, então, com sua parte do trato. Em vingança, o herói decidiu armar uma emboscada e assassinar dois sobrinhos de Augias enquanto estes iam para os Jogos Ístmicos, partindo depois para Elis, tomando-a. Por este motivo, agradecendo a Zeus por sua vitória nesta batalha, teria organizado um ritual perto do túmulo de Pélope, em Olímpia, dando assim, origem aos Jogos.

Em comum nestas histórias, além do agradecimento a Zeus pelo triunfo, está o fato de sempre se associar o culto original a Pélope, pois este era uma figura mítica bastante forte na antiga Grécia, que acabou emprestando seu nome para a antiga Península de Ápia, renomeando-a como Península do Peloponeso, que significa "A ilha de Pélope" (Pélope + nesos) (CABRAL, 2004b).

Olímpia foi aos poucos se tornando importante centro político e religioso. Existem indicações de que já durante os séculos XII e XI a.C. haviam pequenos jogos organizados por Oxilo, mas que por algum motivo ficaram interrompidos por cerca de dois séculos, até que Ífito, um de seus sucessores, apenas no final do século IX a.C. por sugestão do Oráculo de Delfos, 
reorganizou os Jogos em honra a Zeus, sendo isso a solução para uma peste que assolava a região. Então, em 884 a.C., Ífito de Élida, Licurgo de Esparta e Cleóstenes de Pisa entraram em um acordo e declararam Olímpia um lugar sagrado, decretando assim, a primeira "Trégua Sagrada" (Ekekeiria). O texto gravado no disco, que ainda hoje pode ser visto no Museu dos Jogos Olímpicos de Olímpia, diz que:

Olímpia é um lugar sagrado. Quem ouse pisar neste solo com forças armadas, será considerado blasfemo. Também o será, todo aquele que não vingue este crime, estando ele em seu poder?

No início essa trégua tinha a duração de apenas dois meses, um mês antes e um mês depois dos Jogos. Posteriormente esse período foi estendido para três meses antes e três depois dos jogos, e no final, esse prazo era de dez meses, dado que sua influência crescia juntamente com sua extensão territorial, devendo haver tempo para que todos, dos mais próximos aos mais longínquos, pudessem, com tranquilidade e segurança, chegar para assistir às celebrações (DURANTEZ, 1979). A Ekekeiria acontecia não diretamente como uma promotora da paz, mas sim para que os Jogos pudessem acontecer regularmente sem a interferência de guerras ou de disputas políticas (SCHAUS e WENN, 2003). Mesmo que de forma inconsciente, eles já sabiam que o "Movimento Olímpico" não deveria ter objetivos específicos como a paz ou a igualdade em sua essência, ele deveria sim se esforçar para continuar tendo relevância para a sociedade, e a partir disso, ser um veículo para as intervenções sociais necessárias.

\footnotetext{
${ }^{7}$ De acordo com a tradução de DIEN (1966).
} 
De acordo com DURANTEZ (1979), cento o oito anos depois deste acordo, no ano de 776 a.C., foram organizados os primeiros Jogos Olímpicos com periodicidade definida: a cada quatro anos seriam lá celebrados cultos a Zeus, em substituição aos antigos cerimoniais que anualmente eram realizados em honra às forças da natureza e à fertilidade, e a cada oito anos, quando o calendário Lunar coincidia com o Solar, a festa era especial. Nas suas 13 primeiras edições, o evento contava apenas com a corrida de um Stádion, que em Olímpia representava 192,28 metros de comprimento, sendo o maior de toda a Grécia. Corebo de Elis, em 776 a.C. foi o primeiro campeão Olímpico registrado, de um evento que perdurou por 1.169 anos, contando com 293 edições, único na história da humanidade.

O prêmio pelo triunfo era consistido apenas de uma coroa com ramos de oliveira, porém de grande valor para o atleta grego da antiguidade. As Oliveiras eram, e ainda são, uma árvore abundante no Vale do Alfeu. Conta-se que foi Héracles quem teria trazido as primeiras mudas para proteger o Monte Cronos do sol e do forte calor da região. Independentemente de sua origem, as coroas depois de preparadas eram depositadas no Heraión, o templo de Hera, e aguardavam pelos vencedores. Como Hera, juntamente com Demeter, eram denominadas de "Grande Mãe", este pode ser um forte indício da continuidade dos valores de fertilidade e fecundidade que deram origem aos Jogos, mesmo que a principio possam ser vistos apenas como uma exaltação às personificações heróicas exclusivamente masculinas (MUNGUIA, 1992; DURANTEZ, 1979).

Em Olímpia, segundo CABRAL (2004b) e CHRISTOPOULOS (2003), além dos Jogos Olímpicos, existiam os Jogos Heranos que eram restritos à participação apenas de mulheres virgens, tendo em vista que estas, se casadas, não poderiam comparecer aos Jogos Olímpicos sob pena de morte, mas que, no entanto, nunca foi posta em prática. Apenas uma vez foi descoberta uma mulher, 
no ano de 404 a.C. durante a realização das $94^{a}$ Olimpíada, Kallipatira, mãe de Pisirodos, que estando em área proibida para ela, não pode conter sua vibração após o triunfo de seu filho na categoria infantil do pugilato, mas por ser esposa e mãe de vencedores olímpicos, sua vida lhe foi poupada. Os únicos registros que temos de vencedoras nos Jogos Olímpicos são as proprietárias dos cavalos ${ }^{8}$, sendo a princesa espartana Kyniska a primeira delas em 392 a.C., mas que, pelo regulamento, não deve sequer ter visto sua vitória. Os Jogos Heranos, embora não fizessem parte do circuito dos grandes Jogos Pan-Helênicos, eram cercados dos mesmos tipos de honrarias de sua versão masculina, porém, era consistido apenas de um evento, da corrida adaptada de um stádion. Para os homens, a distância percorrida era o padrão de 600 pés, mas para as mulheres era diminuído um sexto de seu tamanho original. Eram realizados um mês antes ou um mês depois da cerimônia dos homens.

DIEN (1966) acredita que a origem dos Jogos Heranos se deva à influência dos espartanos, dado que na Lacedemônia, durante as festas de Ártemis, se realizavam corridas femininas em honra a Dionísio. REESE e RICKERSON (2000) dizem que existiam Jogos Heranos em várias localidades da Grécia antiga, porém, o mais grandioso era mesmo o realizado em Olímpia.

Além destes jogos, outro símbolo cultural de caráter matriarcal bastante importante, segundo HANSEN (1998), foi o culto público a Hestia, simbolizado através de um altar com uma chama que jamais poderia ser extinta, representando a imortalidade da polis. Essa significação sagrada dos valores femininos, de acordo com MASSEY (1988), acabou por direcionar o próprio papel da mulher na sociedade daquele tempo. Diferenças baseadas nas características principais de cada cidade-estado logicamente existiam, como

\footnotetext{
${ }^{8}$ Naquele tempo, os vencedores nas provas de corrida de carro (bigas), eram os proprietários dos cavalos, e não o seu condutor, abrindo, consequentemente, espaço para que as mulheres também pudessem triunfar neste evento.
} 
podemos ver nos exemplos clássicos de Atenas e Esparta. A mulher ateniense era centrada em sua família, não participando da vida publica, ao contrário da mulher espartana, que por lei tinha que ser treinada igual aos homens para que pudessem defender seu território e, de acordo com o que se supunha naquela época, gerar soldados igualmente fortes, porém, não lhes era permitido ir ao campo de batalha (REESE e RICKERSON, 2000). Esse tipo de pensamento era bastante comum naquela época, CABRAL (2004b, p. 126), usa um trecho da obra Anácarsis de Luciano para exemplificar, onde ele coloca:

(...) E nós obrigamos os homens a exercitarem seus corpos não apenas para os Jogos, para que eles possam conquistar os prêmios - pois bem poucos deles chegam até estes - mas porque esperamos obter um bem muito maior para a cidade e para eles próprios.

\subsubsection{Jogos Píticos}

Delfos, referência de muitos Reis e Sacerdotes de todo o mundo antigo em virtude de seu famoso Oráculo, possuía em seu santuário os locais para a prática de atividades físicas, como o Gimnasium e o Stádion, e abrigava o segundo mais importante evento atlético da Grécia antiga, os Jogos Píticos.

Segundo CABRAL (2004a), embora as evidências apontem para uma ocupação daquele território desde o período Neolítico, na região do santuário propriamente dito, as evidências mais antigas são de aproximadamente 1.400 a.C., e pelas estatuetas encontradas, podemos supor que no início, os cerimoniais eram também destinados às forças da natureza, em especial a Gaia. Foi somente depois, provavelmente pela existência de alguma atividade oracular no local, que a associação ao deus Apolo foi instituída, embora não se saiba sua data não com precisão. 
No entanto, o "Hino Homérico a Apolo"9 nos conta uma outra história. Zeus, em uma de suas aventuras amorosas com a ninfa Leto, gerou duas crianças, Apolo e Ártemis, das quais Hera, cheia de ciúmes, em vão tentou impedir o nascimento, pedindo para que Gaia não cedesse nenhum lugar na terra para a ninfa dar à luz, que, no entanto, acabou encontrando refugio em Delos, uma ilha flutuante construída por Poseidon. Uma vez que as crianças nasceram, teria então a deusa enviado um dragão-serpente, chamado Piton, para sempre perseguir a ninfa, na qual Apolo com seu arco, já na adolescência, deu fim. A partir deste dia, o deus passou a ser o guardião do Oráculo de Gaia, que, desde então, foi chamado de Oráculo de Apolo, ou simplesmente, de Delfos.

As cinzas de Piton foram enterradas no centro de Delfos e sua pele foi usada para recobrir o trípode em que se sentavam as sacerdotisas do Oráculo, daí serem chamadas de Pitonisas. Também por este motivo, passaram a ser realizados a cada oito anos, na segunda metade de cada ano de Jogos Olímpicos em edição ímpar, uma competição musical para purificar Apolo do assassinato de Piton e, a partir de 582 a.C., contando com a inclusão do programa atlético, passaram a ser celebrados os Jogos Píticos, também em um período quadrienal (CABRAL, 2004b). Como, além de deus do Sol e da luz, Apolo era também deus da música e da poesia, estes Jogos tiveram grande importância também pelo seu caráter artístico, não só atlético. O sucesso desse evento se devia ao fato de Apolo ser, depois de Zeus, uma das mais importantes divindades gregas, além de nobre orientador de exercícios físicos e patrono dos ginásios e palestras (BRANDÃO, 1998; MENARD, 1991b; OTTO, 2005).

O prêmio pelo triunfo consistia de uma coroa com ramos de louro, cuja árvore era associada ao deus desde que a ninfa Dafne teria se transformado em um loureiro para escapar de sua perseguição. Isso se deu porque Eros, ao mesmo

\footnotetext{
${ }^{9}$ Tradução de CABRAL (2004a).
} 
tempo em que teria deixado Apolo apaixonado pela ninfa, acertou-a com uma flecha de chumbo, que a faria recusar o amor do deus. A única forma que ela encontrou para conseguir dar fim a sua fuga, foi pedindo a seu pai para que a transformasse em uma árvore. Desde esse dia, Apolo levava consigo um ramo de louros como forma de estar junto de sua amada.

\subsubsection{Jogos Nemeus}

Neméia, embora tenha sido uma pequena vila localizada no nordeste da Península do Peloponeso, foi local de importantes acontecimentos, cujos resultados lhe rendeu um dos mais importantes Jogos da Grécia antiga, os Jogos Nemeus.

Sua origem está dividida em duas histórias bastante distintas entre si. A primeira delas envolveu Héracles.

Por ter nascido de uma união extraconjugal de Zeus com uma mortal, Alcmena, o herói teve que, durante toda a sua vida, enfrentar o ciúmes de Hera, esposa do deus, que mesmo antes de seu nascimento já lhe impunha tarefas tidas como irrealizáveis para um simples mortal, que não era o caso de Héracles. Conta uma história que Hermes teria levado o herói ainda criança para o Olimpo, colocando-o sobre os seios da adormecida Hera. Héracles teria então mordido-a tão fortemente que o leite, escapando dali, formou a via Láctea. Além disso, aquele era o leite da imortalidade, condição que o herói realmente alcançou ao final de sua vida (BRANDÃO, 1998; MENARD, 1991c). Mas, muita coisa teria que acontecer até sua morte apoteótica.

Quando ele tinha aproximadamente dezoito anos, estava voltando da caça do Leão do monte Citerão, que estava arruinando os rebanhos de seu suposto pai, e viu os enviados do rei Ergino cobrando impostos dos tebanos, e 
não somente os matou, como fez o mesmo com o próprio rei quando este voltou com um exército ainda maior, obrigando os que conseguiram fugir a pagar o dobro dos impostos que estavam pretendendo receber. Foi a partir deste momento que ele atingiu a maturidade, tendo sua fama reconhecida.

Glória esta que Hera não estava disposta a aceitar tão facilmente. Fez cair sobre o herói uma loucura que o fez matar seus filhos, pensando estar em guerra contra os micênios. Quando ia matar sua esposa, Atenas o fez cair em sono profundo. Quando recobrou a consciência, vendo o que tinha feito, se auto impôs o exílio. Após ter-se purificado, consultou o oráculo sobre o que deveria fazer. Daí veio a sugestão de que fosse até seu maior inimigo, Euristeu, e se submetesse a todos os trabalhos por ele exigido (FRANCISCATO, 2003).

O primeiro deles, foi justamente ir até Neméia para matar um leão que assolava a região, ao qual deu fim com suas próprias mãos, estrangulando-o. Após cumprir esta tarefa, Héracles teria então instituído os Jogos Nemeus em agradecimento a Zeus por sua vitória.

No entanto, existe uma outra história que é mais aceita para a origem destes jogos. Diz a mitologia que os sete grandes chefes que dirigiam o exército em guerra contra Tebas, em razão da disputa pela cidade entre os filhos de Édipo, de acordo com a história de Sófocles - "Os sete contra Tebas", começaram a sentir sede e passaram a procurar uma fonte para saciá-la. No caminho encontraram uma mulher que tomava conta de uma criança chamada Ofeltes, filha do Rei de Neméia e, para que ela pudesse indicar onde estava a fonte, apoiou a criança em uma folha de aipo, por tempo suficiente para que uma serpente sufocasse e matasse a criança. Foi realizado então um grande funeral e instituído os Jogos Nemeus em sua homenagem, nos quais os vencedores se cobriam de luto e eram agraciados com uma coroa de aipo, dado as atribuições telúricas a esta planta creditadas (MENARD, 1991c). 
Quando associamos o caráter fúnebre deste evento com a existência de um grande templo de Zeus dentro do santuário de Neméia, podemos ver que as duas histórias se sobrepõem. Héracles, quando chegou ao Olimpo depois de sua morte terrena, reconciliou-se com Hera, e recebeu a mão de sua filha Hebe como esposa. Por esta representar a eterna juventude, condição buscada por todos os cultos de renovação da natureza, a história se iguala a do jovem Ofeltes, cujo ritual fúnebre buscava a imortalidade de sua memória.

Embora evidências apontem que os jogos já teriam sido realizados anteriormente a 1.251 a.C., sua primeira edição depois de instituída a sua regularidade bienal está registrada em 573 a.C., e seu programa era constituído apenas de jogos atléticos (CABRAL, 2004b).

\subsubsection{Jogos Ístmicos}

Um outro grande evento acontecia no Istmo de Corinto, o principal ponto de ligação da Grécia continental com a Península do Peloponeso, e um dos principais centros comerciais de todo o mundo antigo.

A origem dos Jogos Ístmicos também é cercada de histórias que se confundem. A primeira delas é mais um dos desdobramentos das uniões extraconjugais de Zeus com uma mortal. Dessa vez, foi quando ele se uniu a Sêmele. Quando Hera descobriu, teria sugerido para a mortal que pedisse ao seu amante para mostrar-se em sua verdadeira forma, já que o deus teria prometido que faria qualquer coisa que ela pedisse. Embora arrependido, pois saberia que isso a fulminaria, Zeus se mostrou em todo o seu esplendor, fazendo com que, no mesmo momento, o corpo de Sêmele se transformasse em cinzas. Porém, como ela estava grávida de Dionísio, o deus conseguiu salvar a criança, fazendo com que a gravidez se completasse em sua coxa, e assim que deu a luz, entregou 
a criança em segredo para Ino, irmã de Sêmele. Hera mais uma vez descobriu e enviou um ataque de loucura que fez Ino e seu filho Melicertes se jogarem do alto de um penhasco no mar entre Mégara e Corinto. O corpo de Melicertes foi levado por um golfinho até o Istmo de Corinto, onde teria sido recolhido e colocado em uma sepultura ao lado de um pinheiro, sendo instituídos os Jogos Ístmicos em sua homenagem (BRANDÃO, 1998.; MENARD, 1991c).

Outra versão é atribuída a Teseu, filho de Poseidon. Quando este ia pela primeira vez para Atenas, ao escolher trilhar o caminho por terra, se deparou com uma série de bandidos que estariam a solta pelo Peloponeso desde o exílio de Héracles. Um deles foi Sínis, também filho de Poseidon, que vivia perto do Istmo de Corinto, e era conhecido por amarrar suas vitimas na copa de dois grandes pinheiros curvados um na direção do outro até o solo, de forma que assim que ele soltasse os laços que prendiam as árvores, a vítima fosse despedaçada. O mesmo fim foi imposto a Sínis por Teseu. Mas, por se tratar do filho de Poseidon, o senhor dos mares, o herói teria instituído os Jogos Ístmicos em sua homenagem, como forma de acalmar a sua cólera pela morte de seu filho (BRANDÃO, 1998.; MENARD, 1991c).

A ultima versão diz que Cípselo, um tirano de Corinto que viveu entre cerca de 657 a.C. a 625 a.C., como meio de continuar com a prosperidade da cidade e como forma de agradar a população, teria reinstituído os antigos Jogos Ístmicos, em uma versão mais moderna. E de fato, as escavações apontam que o templo mais antigo foi construído por volta de 700 a.C. e somente em 586 a.C. foi definida sua periodicidade bienal e inclusão como um dos grandes jogos Panhelênicos (CABRAL, 2004b).

Além das disputas atléticas e artísticas, estes jogos tiveram, segundo CABRAL (2004b), uma renomada competição de pintura, dado o importante papel que Corinto exercia nesta arte. Pelas histórias, podemos entender o motivo 
pelo qual, inicialmente, o prêmio alcançado teria sido uma coroa de pinheiro, e posteriormente, dado o caráter fúnebre desta competição, o prêmio pelo triunfo era consistido também em uma coroa de aipo.

\subsubsection{As Panatenaias}

Atenas também possuía um evento importante, muito embora não fizesse parte dos quatro jogos Pan-helênicos, que se chamava Panatenaias, tendo sua periodicidade definida também a partir de 586 a.C. O evento ocorria anualmente, mas a cada quatro edições, a festa, que contava com eventos atléticos e artísticos, era especial. O motivo deste cerimonial era honrar a deusa e patrona da cidade, Palas-Atenas, e tinha como ponto principal a troca do véu da estátua da deusa por um novo, tendo sido também Teseu quem o teria organizado (DURANTEZ, 1979). O prêmio para os vencedores era uma ânfora de azeite, de valor sagrado para os helenos, dado que as Oliveiras eram a grande riqueza da região, e mesmo com a aridez do solo, principal característica da região da Ática, esta árvore florescia, oferecendo sombra e alimento. Sua atribuição como sendo um presente dos deuses vem por estes motivos.

A participação nestes Jogos, pelo menos nos de maior grandeza, era restrita aos legítimos cidadãos gregos, embora muitos estrangeiros desejassem poder participar. Na obra de HERÓDOTO (2001, Hist. 2,160), podemos ver que, certa vez, embaixadores eleus ${ }^{10}$ foram ao Egito e perguntaram aos egípcios se eles tinham alguma sugestão sobre as regras dos Jogos Olímpicos. Responderam-lhes sugerindo a criação de Jogos exclusivos para estrangeiros, demonstrando sua importância e grandiosidade mesmo para os "bárbaros". ${ }^{10}$ Olímpia se localiza na região da Elida, sendo os sacerdotes desta região os organizadores dos Jogos
Olímpicos. 
O ultimo vencedor Olímpico registrado foi Filúmenos de Filadélfia, na Ásia Menor, em 369 d.C., após quase 100 anos sem registros de vencedores, embora evidências arqueológicas apontem que o Santuário foi preservado e remodelado durante esse tempo até seu final definitivo, que se deu em 393 de nossa era quando, por sugestão de San Ambrósio, bispo de Milão, o Rei Teodósio I decretou a extinção dos Jogos, por considerá-los uma festa pagã. Por mais quinze anos, até 408 , eles foram realizados não oficialmente, até que Teodósio II ordenou a destruição completa de todos os templos de adoração a outros deuses que não o pregado pela Igreja Católica, que ajudado por inundações do Alfeu e por mais dois fortes terremotos que atingiram a região, puseram um fim definitivo nestes, que foram, provavelmente, as maiores manifestações culturais de toda a história (CABRAL, 2004b; DURANTEZ, 1979).

Mas afinal, o que sustentava estes eventos que permaneceu forte no imaginário grego por todo o período em que durou a sua civilização?

\subsubsection{Poesia grega}

De tantas criações mitológicas construídas pelos diferentes povos da Antiguidade, nenhuma outra exerceu tanta influência sobre o mundo ocidental como a cultura helênica. Para SOUZA (1999), este fato é creditado às peculiares condições do território grego que permitira, desde o estabelecimento dos primeiros habitantes, acesso ao mar e rotas comerciais com os povos do Oriente, o que facilitava o intercâmbio cultural e favorecia o aparecimento de muitas construções imaginárias.

De acordo com VERNANT (2002), uma das principais características do ser humano é seu pensamento simbólico que incide, sobretudo, no 
pensamento religioso. Na Grécia, o politeísmo não possuía caráter dogmático nem pretensão universalista, posto que se encontrava presente nas práticas sociais da família, do Estado, e em todos os atos do cotidiano, como se pode observar nas obras poéticas e até mesmo algumas não poéticas da época, como podemos ver, por exemplo, Homero de um lado e Heródoto de outro. O politeísmo grego foi, como veremos, produto final de um processo de união de crenças religiosas de divindades indo-européias com deusas da Terra e da Fertilidade desenvolvidas por povos do Mediterrâneo, associados a ideias asiáticas, vindo da Pérsia e, principalmente com as egípcias.

Muito conhecemos hoje sobre as artes e as poesias gregas, mas, de acordo com OTTO (2006), existe algo de não pequeno valor que escapa aos olhos de muitos admiradores desta cultura. Conseguimos, segundo o autor, na maior parte das vezes, enxergar as formas da criação humana, mas por vezes deixamos de lado a divindade que existe por detrás dela. A religião grega não era uma forma de entendimento da alma humana, mas sim da revelação da essência das "coisas" do mundo. Em relação a isso, diz o autor (p. 48/49) que:

Os gregos receberam uma mensagem que pode chamar-se 'Revelação' no sentido mais pleno da palavra: uma mensagem divina tal como nenhum outro povo a recebeu. Ela não lhes proclamou a majestosa grandeza de um deus criador do mundo, de um legislador, de um salvador; faloulhes do que existe, e assim como existe, quer signifique alegria ou dor para os humanos, da testemunho da presença do divino e da sua bem-aventurada majestade.

Não vemos nela uma característica comum em outras formas de religião que são as promessas de salvação pós-morte, no lugar disso vemos que o divino proporciona aos homens a revelação de seu próprio ser, trazendo do futuro para o presente "os magníficos momentos da eternidade" (OTTO, 2006, 
p. 103). A divindade revela ao homem sua verdadeira nobreza apenas pelo seu ser, não através de ensinamentos. Vemos, principalmente nas obras de Homero, que os deuses dirigem todas as principais ações e até mesmo as vontades dos homens, porém, ao invés de tirar-lhes a liberdade, garantia o amparo sem o qual a "liberdade verdadeira não poderia existir" (p. 101).

Mais uma vez temos um exemplo de Homero, que não apenas nos deu dicas sobre a organização da família olímpica, como nos revelou também os limites da existência humana através do retorno de Ulisses. O herói vai até as fronteiras do Hades, onde os mortos sem honrarias fúnebres erram sem poder entrar, ouve o cantar mortal das sereias e escapa dos desejos ultraterrenos dos Lotófogos, da deusa Circe e da ninfa Calipso. Apenas quando encontra os Feácios, que pela ultima vez foram vistos por Ulisses, é que ele pôde, enfim, cruzar a fronteira que o separava entre o mundo divino e o mundo mortal. Esse povo, embora pertencente ao mundo fantástico, eram também comedores de pão, uma atividade essencialmente humana, por isso somente eles poderiam devolver Ulisses ao seu verdadeiro mundo (HARTOG, 2004).

A mitologia grega, portanto, foi um conjunto de narrativas de Deuses e Heróis, e estes, por ocuparem um lugar central no imaginário daquela sociedade, eram os dois principais grupos de personagens de culto dos cidadãos gregos e, como consequência disso, tinham nas manifestações religiosas seu ponto máximo de expressão (VERNANT, 2002). Isso só pode acontecer, segundo OTTO (2006), porque os gregos encaravam seus deuses como uma forma vivente, sendo possível somente através desta maneira compreender a grandiosidade dos cultos e a superação dos homens em busca da transcendência desde os campos de batalha, passando pelos rituais agonísticos, até o mais simples modo de ser. A ideia dos gregos, portanto, não era o antropomorfismo, tornando os deuses em humanos, mas sim tomar um caminho contrário, em 
realizar um Teomorfismo, "endeusando" os homens. Culto não existe sem mito, é justamente através dos rituais que os mitos ganham forma, sendo este o lugar onde deuses e homens se encontram, momento a partir do qual a existência ganha forma.

Assim, a Grécia se torna um grande exemplo de Civilização, pois, segundo muitos pensadores, constitui-se como o ponto de partida para compreender a ciência e a filosofia, além de também ser o berço da política, da democracia e, sobretudo, da razão como a entendemos. Proporcionou à cultura Ocidental estes que são seus traços mais marcantes e, tentar explicá-la, "é tentar situar nossa própria origem no lugar que lhe cabe na história" (VERNANT, 2002, p. 18). A prática esportiva de hoje, um dos principais fenômenos contemporâneos, é de certa forma uma continuidade do que ocorreu na Grécia vários séculos antes de Cristo, atestado por construções que desafiaram o tempo e, por isso, ainda atestam, com suas formas e histórias remanescentes que sobreviveram sob forma de poesias, os feitos ocorridos dando vívidas representações do cotidiano helênico.

Os poetas tiveram grande responsabilidade sobre essa construção mitológica, e em suas histórias estão documentados e transmitidos os principais valores de apropriação e compreensão dos fenômenos naturais. NAGEL (2006), diz que os poetas permitiram, através de seus cantos, que nós olhássemos para o cenário da formação humana em cada momento histórico. HERÓDOTO (2001), que viveu durante o século V a.C., aproximadamente entre 485 a 420, ao apresentar sua obra "História", durante a 84ª Olimpíada, no ano de 444 a.C., mostra que, já naquele tempo, a poesia ocupava esta função. Conforme o autor:

Durante muito tempo ignorou-se a origem de cada Deus, sua forma e natureza, e se todos eles sempre existiram. Homero e Hesíodo, que viveram quatrocentos anos antes de mim, 
foram os primeiros a descrever em versos a Teogonia, a aludir aos sobrenomes dos deuses, ao seu culto e funções e a traçar-lhes o retrato (Hist. 2, 53).

A teologia grega, segundo CAMPBELL (1994), não foi formulada por clérigos ou profetas, mas sim por artistas, filósofos e principalmente pelos poetas. Como diz FERREIRA SANTOS (2004b), é principalmente "através do canto que os mitos de origem, as ações dos deuses e a memória do passado primordial são ensinados" (p. 18), sendo o canto a forma que estabelece a conexão entre as forças da natureza com os próprios seres humanos. As personificações eram trazidas à existência pela criatividade e imaginação humana sem ninguém ditar os termos da crença. A poesia grega buscou de várias maneiras procurar entender o mundo da forma como ele é e de como ele foi formado. DIEL (1991) diz que os simbolismos contidos em suas histórias exibem, de forma geral, a origem da vida, a exaltação e seus perigos, a banalização e a luta contra ela. Segundo VERNANT (1990), e corroborado por TORRANO (2003), na filosofia, o mito é racionalizado, ou seja, ele toma a forma de um problema explicitamente formulado, sendo ele a narrativa, não a solução. O problema achava-se resolvido, mesmo sem na verdade ter-se posto. Os deuses helênicos, segundo o mesmo autor, são uma espécie de força natural, não indivíduos propriamente ditos.

O pensamento religioso, portanto, corresponde ao problema de organização e de classificação dessas forças, distinguindo diversos tipos de poderes sobrenaturais através de suas dinâmicas, seus modos de ações, domínios e limites, considerando também toda sua complexidade de hierarquia, equilíbrio, oposições e complementaridade que com o tempo vai ganhando.

Outras vezes, as poesias apenas representam um período histórico pelo qual aquela sociedade estava passando, como por exemplo, quando se referiam a 
"Idade das trevas helênica", um período compreendido aproximadamente entre os séculos XI e o VIII a.C., nos quais a língua grega deixou de ser escrita, além de os povos daquela época possuírem poucos conhecimentos de imagens elaboradas, também não desenvolveram nenhum sistema de representação figurada. Paralelo a isso ocorria a batalha entre as forças divinas descrita pelo poeta Hesíodo em "A Teogonia”. Nesse momento Zeus lançou seu raio e os Hecatonquiros ${ }^{11}$ se precipitaram sobre os Titãs ${ }^{12}$, dando inicio à Titanomaquia, levando o mundo a retornar a um estado caótico, ao estado primordial da desordem original, do Kháos. A vitória de Zeus simboliza a necessidade de refazer o mundo, ou seja, ela não é apenas a vitória sobre um adversário, mas a recusa a um mundo de desordem. A reconstrução a partir dessa massa invisível e disforme pode representar a reconquista progressiva da forma, com deuses predominantemente antropomórficos, e com uma estrutura organizada, assim como a sociedade em que os próprios humanos estavam desejando viver (VERNANT, 2000; 2002).

Portanto, através da poesia se torna possível acessar o passado mitológico da Grécia com relativa precisão, assim como se torna possível compreender como se deu o processo de apropriação da realidade pelos helenos. A cosmogonia grega, de acordo com o trabalho de BRANDÃO (1996), inicia-se com o Caos, uma massa disforme e confusa, personificação do vazio primordial anterior a criação. Surgiram depois as três primeiras divindades, dando forma ao mundo: Gaia (a terra); Tártaro ("a mais profunda das entranhas da terra”, p. 186); e Eros (o amor), representando a força invisível da união entre os seres. Posteriormente, surgiram ainda do Caos, Érebo, que representava as trevas, e

\footnotetext{
${ }^{11}$ Os Hecatonquiros foram três gigantes de cem braços filhos de Urano com Gaia, que foram aprisionados primeiro pelo próprio Urano e depois por Cronos, mas posteriormente foram libertados por Zeus que os teve ao seu lado nesta batalha.

${ }_{12}$ Os Titãs, como veremos, representam divindades primordiais, geralmente associadas aos descendentes de Urano e Gaia.
} 
Nix (a noite). Deste ultimo surgiram suas complementaridades, Éter e Hemera, que representavam respectivamente a luz do céu e o dia.

Destas divindades, ainda de acordo com BRANDÃO (1996), surgiu a primeira geração da família Olímpica, Gaia gerou sozinha a Urano, Montes e Pontos, que, continuando a dar forma ao mundo, representavam o Céu, as Montanhas e o Mar, respectivamente. Como Urano também representava a chuva, consequentemente, acabou por fecundar a terra, ou seja, Gaia, gerando com isso a segunda geração de Deuses, denominados de Titãs, representando as manifestações elementares da natureza. Destes, o principal é Cronos que destronou seu pai e assumiu o controle do mundo, tomando Reia, que além de ser sua irmã era a antiga deusa cretense da fertilidade, como esposa. Essa união acabou por gerar a terceira e ultima geração divina, consistida por Zeus, Hades, Poseidon, Hestia, Demeter e Hera.

Cronos, ao destronar seu pai, foi por este advertido que o mesmo lhe sucederia, por isso, a história nos conta que ele devorava um a um todos os seus filhos $\log$ após os seus nascimentos, pois por representar o tempo, nada escaparia à sua finitude. Porém, Reia consegue salvar Zeus, o caçula, dando ao seu marido uma pedra para ser devorada em seu lugar, enviando a criança para uma gruta em Creta para ser escondido e cuidado. Quando enfim alcançou sua maturidade, Zeus iniciou uma batalha contra seu pai, mas não sem antes the fazer ingerir uma droga que o fez vomitar todos os filhos antes devorados. Essa batalha, que envolveu todos os deuses do Olimpo, é por Hesíodo descrita em seu poema "A Teogonia", sendo que logo após o seu final, o universo retornou à sua ordem. $\mathrm{O}$ mundo era agora governado por Zeus, que deu as profundezas da terra aos cuidados de Hades e os mares para Poseidon.

O politeísmo contido na complexa mitologia da religião grega surgiu, portanto, como resultado da atribuição do divino na natureza, baseado nos 
mistérios do mundo exterior e no inconsciente dos próprios homens, sendo a principal forma como eles conseguiram se organizar para que sua cultura se tornasse permanente em seu mundo.

A ideia de Zeus já era bastante conhecida por quase todas as culturas indo-européias, que o tinham como suprema divindade. Ele unia em uma só pessoa os ideais de virilidade masculina com a fertilidade essencialmente feminina. Seus poderes estavam associados à força da tempestade, por meio do poder do raio, ao mesmo tempo em que a água da tempestade poderia fertilizar a terra. Era ainda o protetor da família e da polis. Seus diversos casamentos são uma clara evidência dessa união política entre os povos invasores com as culturas locais pré-helênicas. Mais tarde, foi unido a Júpiter, deus romano da fertilidade.

Encontramos, assim, na obra de Hesíodo, um "modelo" do pensamento que pareceu comandar a mais antiga experiência religiosa do espaço e do movimento que os gregos poderiam ter. De forma geral, o poeta nos mostra a estrutura de seus mitos, que se baseiam predominantemente na tensão entre a Díke e a Hýbris (respectivamente - escuta a justiça; não deixes aumentar a desmesura), e não só ordena a construção do mito em seu conjunto como the atribui significado, conferindo seus níveis funcionais, mantendo seu aspecto de polaridade (ELIADE, 1983b).

Uma das construções mais significativas que Hesíodo legou à humanidade foi o mito do sacrifício de Prometeu, em que há a separação entre os homens e os deuses. Prometeu planeja uma trapaça para os deuses, onde durante a realização de um cerimonial, ele faz uma armadilha para que, após o sacrifício de um animal, os deuses ficassem com os ossos (imortais), enquanto que os homens ficariam com a carne (mortal). Para isso, fez Zeus escolher entre um animal somente com pele, gordura e ossos, e outro mais magro, porém, 
somente com os músculos, ou seja, com a parte comestível do animal. O Deus não teve duvidas em escolher o mais robusto, e ao se ver caindo na armadilha, zangou-se e como castigo privou os homens do fogo divino. Prometeu uma vez mais tentou ajudar os homens, e conseguiu devolver este fogo, mas não um fogo imortal, posto que precisaria ser sempre alimentado. A estrutura deste mito, como diz LAFER (2002), estabelece os fundamentos da condição humana na Antiguidade, separando os homens dos deuses, fazendo-os habitar mundos distintos. Desde então, nos cerimoniais, a gordura retirada do animal sacrificado é colocada no fogo sagrado como oferenda aos deuses, enquanto os homens compartilham a parte comestível.

Por fim, como castigo final, Zeus deu aos homens a primeira mulher, personificada na figura de Pandora, levando consigo uma caixa contendo todos os males que, se aberta, afligiriam a humanidade. A partir de então, ao fazer os sacrifícios, os homens se submetem aos desejos dos deuses, que desde a armadilha de Prometeu, fizeram mortais e imortais viverem em mundos bastante distintos. O cerimonial aponta essa divisão: os sacrifícios se tornam, portanto, a única maneira de contato com o divino, deixando de ser apenas simples comemorações para se tornar uma espécie de re-atualização, ou seja, a busca do espaço e do tempo sagrado original, denominado por ELIADE (1969) como o "Mito do eterno retorno". E de acordo com BERTON (1990), é a partir desta ótica que o templo se transforma no substituto deste centro primordial. Com isso, o tempo mítico e o espaço sagrado repetem-se até o infinito.

Hesíodo mostra em "O Trabalho e os Dias" a evolução da humanidade em cinco idades, das quais acreditamos que, em princípio, existiam apenas quatro, iniciando-se com a Idade de Ouro, depois a de Prata, de Bronze e por fim, a de Ferro, que fez o poeta lamentar o fato de 
Mais cedo tivesse morrido ou nascido depois.

Pois agora é a raça de ferro e nunca durante o dia cessarão de labutar e penar e nem à noite de se destruir (v. 174 -177).

Além destas, existiu mais uma raça que possivelmente teria sido posteriormente incluída nesta estrutura, porém, sem correspondência metálica, que foi a raça dos Heróis, a qual se encontra entre as raças de Bronze e a de Ferro. Foi a mais bela e justa, e por serem considerados semideuses, dado que sua concepção se dava entre um Deus com uma humana ou vice-versa, depois de suas mortes encontraram paz e tranquilidade na ilha dos Bem-aventurados. Para ELIADE (1983b), o poeta interrompe inexplicavelmente o processo de degradação iniciado pela raça de prata, pois não poderia ignorar a poderosa lembrança mitificada da "lendária época heróica" (p. 85). Hesíodo não os teria incluído em sua cronologia sem uma boa razão.

De acordo com VERNANT (1990), quando a tragédia nasceu na Grécia, os heróis, imaginários ou reais, foram frequentemente usados como exemplos para a educação, pois apresentavam certos aspectos do homem em situações de agir, principalmente estando na encruzilhada de importantes decisões, deliberando em torno das consequências de seus atos, visualizando sua posição diante do destino, e das responsabilidades em relação a seus feitos, cuja origem e fim ultrapassam toda a ambiguidade de todos os valores propostos à sua escolha, tendo que, portanto, tomar a decisão.

Estas personagens, segundo VERNANT e VIDAL-NAQUET (2008), não eram inventadas para se adequar à trama, eles já estavam fixados no saber comum dos gregos como parte viva de seu passado. Nas obras "A Ilíada" e "A Odisséia" o termo herói não possui nenhum significado de culto. Ele poderia identificar um príncipe ou apenas um simples guerreiro, o que não significa que 
não houvesse cultos em túmulos de personagens que viveram em tempos passados. Evidências arqueológicas apontam que, na segunda metade do século VIII a.C., se desenvolveu rapidamente, em diversas regiões da Grécia continental, a reutilização para fins religiosos de sepulturas micênicas caídas em desuso. Foi nesse momento, ainda de acordo com os mesmos autores, quando um culto passou a estar ligado a uma tumba real ou de alguma pessoa importante, é que tivemos o nascimento do herói. As figuras lendárias possuíam cultos funerários distintos daqueles em relação a parentes próximos. Hesíodo, portanto, foi o primeiro a defender os heróis como categoria diferente de humanidade, posto que em um primeiro momento entendemos que ele não os teria incluído em sua estrutura mítica, fazendo-o posteriormente sem nenhuma correspondência metálica como o fez com as outras raças, denominando-as de ouro, prata, bronze e ferro.

CAMPBELL (1995), ao notar uma sequência em comum na jornada mitológica dos heróis, sintetiza da seguinte forma sua evolução:

O herói mitológico, saindo de sua cabana ou castelo cotidiano, é atraído, levado a se dirigir voluntariamente para o limiar da aventura. Ali, encontra uma presença sombria que guarda a passagem. O herói pode derrotar essa força, assim como pode fazer um acordo com ela, e penetrar com vida no reino das trevas (batalha com o irmão, batalha com o dragão, oferenda, encantamento); pode, da mesma maneira, ser morto pelo oponente e descer morto (desmembramento, crucificação). Além do limiar, então o herói inicia uma jornada por um mundo de força desconhecidas e, não obstante, estranhamente íntimas, algumas das quais o ameaçam fortemente (provas), ao passo que outras lhe oferecem uma ajuda mágica (auxiliares). Quando chega ao nadir da jornada mitológica, o herói passa pela suprema provação e obtém sua recompensa. Seu triunfo pode ser representado pela união sexual com a Deusa-Mãe 
(casamento sagrado), pelo reconhecimento por parte do paicriador (sintonia com o pai), pela sua própria divinização (apoteose) ou, mais uma vez, se as forças se tiverem mantidas hostis a ele, pelo roubo, por parte do herói, da benção que ele foi buscar (rapto da noiva, roubo do fogo); intrinsecamente, trata-se de uma expansão de consciência e, por conseguinte, do ser (iluminação, transfiguração, libertação). O trabalho final é o do retorno. Se as forças o abençoaram, ele agora retorna sob sua proteção (emissário); se não for esse o caso, ele empreende uma fuga e é perseguido (fuga da transformação, fuga de obstáculos). No limiar de retorno, as forças transcendentais devem ficar para traz; o herói re-emerge do reino do terror (retorno, ressurreição). A benção que ele traz consigo restaura o mundo (elixir). (p. 241)

No mundo de Hesíodo, contudo, parece não haver lugar para a função guerreira nem para o guerreiro como o mito o relata. A transformação do guerreiro da epopeia em Hoplita, o simples soldado grego, combatendo em uma formação unida, não apenas marcava uma revolução na técnica militar, como também do ponto de vista da ordem religiosa e social, uma mudança significativa.

Mas, o que existia nas poesias que davam força a essas construções imaginárias?

VERNANT (1990) aponta que os poetas têm uma experiência imediata dessas épocas passadas porque têm o poder de presenciar o passado, invocando as musas para isso, até mesmo porque, segundo OTTO (2006), elas foram justamente "feitas" para perpetuar as obras dos deuses. Era frequente que eles transferissem de seus textos a responsabilidade para as musas, como coloca Hesíodo no próprio titulo da Teogonia - "Hino das musas a Zeus pai", e logo na primeira linha "Pelas musas Heliconíades comecemos a cantar", fazendo igual em $O$ Trabalho e os Dias - "Musas Piérias que gloriais com vossos cantos..." 
(TORRANO, 2003; LAFER, 2002); como Homero o faz nas primeiras linhas de suas obras, colocando na Ilíada - “A ira, Deusa, celebra do Peleio Aquiles”, e na Odisséia - "Canta para mim, ó musa..." (CAMPOS, 2002, 2003; CARVALHO, 2002); e posteriormente copiado por Virgilio - "Musa, as causas me aponta, o ofenso nume” (I, 15) (RODRIGUES, 2005). Elas eram filhas de Zeus com Mnemosine, aquela que preserva do esquecimento, servindo como ponto de ligação entre os acontecimentos terrenos e os divinos, com o presente e o não-presente, atribuindo-lhes um valor sagrado (SNELL, 2001).

Depois de sua "pré-história" e do desenvolvimento e queda das culturas minóica e micênica, as duas grandes civilizações que ocuparam a região da Península do Peloponeso anterior ao aparecimento da cultura helênica propriamente dita, ocorreu uma grande transformação logo após o colapso desta última, durante a já mencionada "Idade das trevas helênica", um período compreendido entre os séculos XI e VIII a.C., do qual quase nada se sabe a respeito, e cujo desenvolvimento veremos mais adiante (JAGUARIBE, 2002). Foi nesta época que houve a importante transição de uma poesia puramente oral para uma poesia escrita, ou que começava a sê-la. $\mathrm{O}$ fato de o poeta poder criar por sua própria conta, ganhando sua independência e autonomia, começou aos poucos a gerar nessa sociedade uma nova condição, dando inicio a uma forma de encarar a realidade completamente diferente do que viviam até então, se desprendendo da passividade frente à natureza para dar estrutura ao pensamento filosófico. O logos propriamente dito, surge na Grécia um pouco depois, incentivado diretamente pelo debate público argumentado, livre e contraditório, existente na raiz funcional das polis gregas (VERNANT, 2002).

A crise de percepção do tempo se deu no mundo grego pouco depois, por volta do século VII a.C., quando o homem se voltou para sua própria vida emocional e, entregue ao momento presente, sentiu no tempo que passa os 
valores aos quais estava, desde então, ligado. Essa mudança refletiu toda uma ordem de preocupações e exigências estranhas à poesia de Homero e Hesíodo. Corresponde a uma reflexão sobre a salvação que no decurso do pensamento que cerca essa investigação e segue passo a passo com uma reflexão, filosoficamente elaborada, acerca dos problemas do tempo e da alma.

A palavra "Filosofia", que significa "amor à sabedoria", foi inventada pelos gregos durante esta época, como consequência da aparição desta nova forma de pensamento. Contudo, jamais poderemos precisar um inicio absoluto de sua história propriamente dita (HADOT, 1998).

Podemos entender como filosofia a busca, a seu modo, por respostas às perguntas que os mitos e as ideias religiosas tinham tentado enfrentar. E de fato, ela teve sua gênese quando o homem começou a tentar entender o mundo, ensaiando respostas aos seus questionamentos, mas não por meio da religião ou por explicações dadas e impostas pela tradição, e sim por meio da razão. Foi em meio a esse processo que começou, principalmente através da escola de Aristóteles, uma incessante busca de informações de todos os campos do saber. Devemos a esse fato, segundo HADOT (1998), a construção dos registros dos vencedores dos principais Jogos helênicos desde seu inicio, fato que antes não era tido como importante, e que com essa busca por dados mais concretos, passou a ser. De acordo com CABRAL (2004b), foi o sofista Hípias de Elis quem pela primeira vez compilou uma lista dos vencedores olímpicos por volta do ano 400 a.C., e que posteriormente foi revisado e continuado pelo próprio Aristóteles.

E esse foi o grande mérito dos Jônios que, segundo OLIVA e GUERREIRO (2000), foi também ao mesmo tempo o que os diferenciou dos antigos poetas e dos pensadores cosmogônicos, a busca das respostas estavam em relações de caráter causal. Ao pé da letra, Kosmos significa "cabelo bem 
penteado", mas a ideia contida por trás disso era a noção de um "todo ordenado".

Por isso, de maneira geral, as cosmogonias buscam pela origem e o fundamento de todas as coisas, e a principal introdução feita pelos filósofos présocráticos em relação a isso foi de realizar esta busca pautados em "razões" nas quais se pudessem fundamentar. O mito foi sendo sobrepujado pelo olhar frente à natureza fora das lentes "Homéricas" e "Hesiódicas" (OLIVA e GUERREIRO, 2000).

A filosofia, no entanto, não aparece como destruidora das ideias mitológicas, procurando substituí-las. Ela era, assim como os mitos, ao mesmo tempo ciência e vida na antiguidade. A bem dizer, de acordo com HADOT (1998), filosofia e mito partilhavam de estreita relação, pois se encontravam na vida social, nos cultos, nas obras de arte e na literatura, porém, os filósofos a vivem filosoficamente e as transformam em filosofia. Talvez por isso eles tenham ganhado a fama de serem apenas sofistas, e que deixando de lado sua ciência, seriam inferiores aos outros nos acontecimentos do cotidiano.

As ideias filosóficas eram geralmente lidas e divulgadas em sessões de leituras públicas, estando dessa forma diretamente relacionadas com a oralidade. Por isso a sua prática não era fácil. HADOT (1998) diz que os exercícios filosóficos seguiam a mesma linha dos exercícios atléticos, sendo aperfeiçoados através da repetição. Geralmente nos ginásios aconteciam também aulas de filosofia, dado que os antigos helenos acreditavam que o desenvolvimento harmônico de corpo e alma, de acordo com o principio do Kalokagathia (Kalo belo, Agathós - bom), a busca pelo bom e pelo belo, bom de espírito e belo de corpo, educavam os homens verdadeiramente nobres.

Ou ainda, conforme pensamento de Pitágoras, citado por OLIVA e GUERREIRO (2000, p. 61): 
Os homens entram na vida de modo semelhante a uma multidão indo para um festival. Alguns vão vender suas mercadorias para ganhar dinheiro, outros participam dos jogos para exibir sua força muscular ou suas habilidades corporais, ao passo que um terceiro grupo de homens vão tão somente para admirar as belas obras de arte, os belos desempenhos dos atletas e os discursos dos oradores. Algo semelhante ocorre no plano da vida comum: é como se cada um de nós estivesse vindo de longe e trazendo consigo sua própria concepção da vida. Alguns de nós só deseja riqueza, outros vão se esforçar para obter prestigio, enquanto uma minoria nada quer a não ser contemplar as mais belas coisas.

\subsubsection{A Poesia e os Jogos}

Tendo vivido no final do século VIII $a$.C. os dois principais poetas tiveram a oportunidade de presenciar o início destes grandes Jogos Públicos, e em especial os Olímpicos. Pelas suas poesias, podemos compreender um pouco como os gregos daquela época enxergavam o mundo. Suas obras transcendiam os valores de manuais didáticos, ensinavam e expunham os problemas do cotidiano, camuflados em forma de versos. Essa característica da poesia permite observar como era presente a figura do herói naquela sociedade, e como ela influenciou tanto na gênese como no desenvolvimento das práticas atléticas agonísticas e posteriormente competitivas.

É desta época a origem da figura do herói, que pode ser identificado como um indivíduo que se sobressaía em sua sociedade, sendo capaz de realizar grandes feitos e que ultrapassava sua condição de simples mortal e se aproximava dos deuses. Era visto pelos habitantes de sua região como um semelhante, isto é, em iguais condições de existência, o que o tornava um 
exemplo possível, uma referência para os mais jovens. Como Homero nos mostrou precisamente na "Odisséia", a figura heroica estava diretamente relacionada a uma figura atlética, facilitando o entendimento de porque os principais Jogos, de acordo com suas histórias, estavam vinculados em seu início, a importantes heróis.

Um dos principais motivos da crescente importância deste personagem mítico é que, para os gregos, apenas uma coisa podia escapar à destruição: a glória de nossos nomes, as façanhas e os bens comuns feitos ao seu grupo social, sendo justamente neste ponto que residia a imortalidade, na memória dos homens, e pelos cantos dos poetas (RUBIO, 2001). Aquiles é o perfeito exemplo desta imortalidade, ao recusar voltar para a sua casa e ter uma vida longa, optou por uma vida terrena mais curta, porém sua fama se perpetuou no tempo. Para ser reconhecido, cada individuo precisa se colocar no olhar do outro, fazendo com que ele só exista pelo que o outro vê nele, só assim será possível conquistar a glória.

Hesíodo, tanto em "A Teogonia" como em "O Trabalho e os Dias", descreve a raça dos heróis como sendo semideuses, ou seja, nasciam da união de um deus com um mortal ou vice-versa, e já traziam consigo as duas principais virtudes para o homem grego da antiguidade, a Timé (honorabilidade pessoal), e a Areté, melhor traduzida como virtude ou excelência, considerada condição moral que sustentava e direcionava o modo de ser do cidadão grego por volta do século VIII a.C. (JAEGER, 2003). Este princípio pregava principalmente um modo de vida nobre e cavalheiresco, exposto na própria alma do herói homérico. Por outro lado, permeando seus princípios, podiam ser vistos também elementos essencialmente femininos, como a beleza do seu corpo (Afrodite), a constância e respeito pelas leis matrimoniais (Hera) e sua habilidade para inspirar futuros heróis a realizarem feitos patriarcais excelentes, como a deusa Atena. Essa 
alusão à deusa Atena não é por acaso, afinal ela é filha de Zeus, que por sua vez teria sido criado e educado em Creta, cujos rituais possuíam predominantemente imagens de deusas, não havendo, segundo ELIADE (1983a, p. 162), "a menor prova da existência de um deus adulto do sexo masculino". Mesmo a ordem olímpica sendo essencialmente patriarcal, ainda escondia fortes princípios femininos que foram preservados, inconscientemente ou não, pelos antigos habitantes daquele mundo em transição (CAMPBELL, 2004).

Por serem necessariamente filhos de um mortal, essas virtudes eram acompanhadas de características humanas e, nos Jogos Públicos da Antiguidade, os atletas procuravam com o triunfo transcender essa condição de mortal, adquirindo o status de herói. E mesmo que seus feitos não tenham relação direta com os Jogos, como diz ELIADE (1969), desfrutavam de um prestigio religioso considerável, ajudavam a alimentar o imaginário daquela sociedade estimulando a representação de seus feitos em rituais, que viriam a se tornar eventos esportivos, além de suscitar a imaginação literária e artística. Segundo RUBIO (2001), eles são frequentemente honrados pela sua comunidade em virtude de seus feitos, ganhando enorme importância por representar a possibilidade do "vir a ser", se tornando exemplo para os mais jovens e motivo de admiração para os mais velhos e até mesmo para os adversários, o que acabou se tornando a essência das práticas atléticas de caráter competitivo. TUCIDIDES (2001) conta a história de Dorieu de Rodes, que em uma batalha combatia juntamente com o exército espartano e acabou sendo capturado pelos atenienses. Estes, assim que o reconheceram, pois era o então tri-campeão olímpico do Pancratio (432, 428 e 424 a.C.), mandaram imediatamente libertá-lo sem a necessidade do resgate.

Não só em relação às práticas atléticas, Hesíodo também colocou o trabalho no pensamento religioso elaborado, como é possível observar em seu poema "O Trabalho e os Dias". A agricultura, assim como a guerra, não aparece 
como um ofício, mas em ambas o homem experimenta sua dependência com relação às forças divinas, havendo a necessidade da realização de cultos antes de suas práticas. O templo foi feito para alojar a estátua de um deus, que por sua vez foi feito para exteriorizar a presença do deus na intimidade de sua morada (BERTON, 1990). Os rituais dentro dele celebrados são uma repetição do gesto sagrado praticado na origem pelos deuses e até mesmo por heróis, re-atualizando as ações sagradas, abandonando o tempo profano, entrando, segundo ELIADE (1969), em uma espécie de momento mítico atemporal, ao qual o autor denominou de "Mito do eterno retorno". Na descrição da jornada do herói, proposta por CAMPBELL (1995), transcrita anteriormente, também podemos observar esta mesma característica, de Separação - Iniciação - Retorno, sendo considerado por ele como a "Unidade nuclear do monomito".

POLIGNAC (1984) diz que normalmente se atribui a origem destes rituais aos heróis como resultado da influência dos poemas homéricos, os quais dão grande valor ao personagem nobre-herói. Porém, o autor discorda dizendo que provavelmente estas tumbas eram cultos divinos mal definidos que foram realizados e abandonados no passado do que verdadeiros cultos heroicos. Estes novos cultos se iniciaram no final do século VIII $a$.C., quando por volta dos anos 750 a 700 a.C. foram achadas muitas tumbas micênicas que revelavam oferendas e sacrifícios a heróis. Foi nesta época que, independentemente de sua verdadeira função na origem, estes cultos foram aos poucos se desenvolvendo dentro de sua característica agonística para se tornarem os grandes Jogos Públicos, como por exemplo, o mais famoso realizado em Olímpia, os Jogos Olímpicos. Mesmo que nesses cerimoniais os valores patriarcais fossem colocados em evidência, o prêmio alcançado por quem triunfasse era uma coroa com ramos de Oliveira, cuja árvore possuía valor especial para o atleta grego, por ser uma das grandes riquezas naturais da região, tendo também um 
importante significado feminino, e por isso, depois de preparadas as coroas com seus ramos, eram depositadas no Heraión, o Templo de Hera, esposa de Zeus e aguardavam os vencedores (DURANTEZ, 1979; MACHADO, 2006).

O início destes cerimoniais se deu em um tempo em que a Grécia se reestruturava depois da queda de Micenas. Ao mesmo tempo em que esses antigos cultos foram se reorganizando, a estrutura social da Grécia vinha se reestruturando, as pequenas tribos iam crescendo e se unindo, formando as primeiras polis. $\mathrm{O}$ antigo sistema de governo consistido em um grupo de nobres em torno de uma monarquia hereditária, foi aos poucos sendo substituído por uma aristocracia, suprimindo-se a figura do Rei, formando a classe dos Eupátridas, responsáveis pelo governo (JAGUARIBE, 2001). Muitas tomadas de decisões, segundo FINLEY (1983), foram realizadas após a conclusão de um ritual, mostrando a relevância deles para os povos da antiguidade. Esse fato se constituiu em importante elemento para a propagação dos mitos, dos nomes dos deuses, dos gestos rituais, enfim, em uma cultura essencialmente oral, e essa possibilidade de transmissão cultural acabou se tornando decisiva.

Essa possibilidade de união cultural, segundo POLIGNAC (1984), teve importante reflexo no campo de batalha, onde o tipo de combate singular retratado por Homero deixa de existir, dando espaço a uma nova tática militar, reunindo os soldados em falanges, uma espécie de massa compacta onde as ações são tomadas coletivamente, representando um aumento de poder tanto de ataque, quanto de defesa. Estas falanges sempre representavam suas cidades, ou seu grupo social, não deixando de ter, também na guerra, uma importância política. 


\subsubsection{Mitos e deuses}

Pudemos observar que o desenvolvimento das cidades-estado gregas acompanhou durante o tempo o desenvolvimento das principais ideias originadas da mitologia, ajudando na transformação das concepções do mundo para ideias mais elaboradas, culminando na criação de grandes eventos que transcendiam seus valores originais. Porém, por muito tempo ainda se via a manutenção de seu caráter agonístico inicial.

Os deuses eram a explicação de todos os fenômenos naturais, e responsáveis pelos acontecimentos da vida cotidiana, como bem podemos observar no desenrolar homérico da Guerra de Tróia. Mesmo as ações humanas não escapavam de um inicio independente, partia-se do princípio de que tudo que era estabelecido e realizado era obra dos deuses, não tendo em si seu principio, nem um fim próprio. A dificuldade em diferenciar mito e realidade na Grécia antiga vem já desde aquele tempo, como podemos observar nas obras de Tucidides e Heródoto quando, por exemplo, se referiam ao Rei Minos de Creta, colocando-o a meio caminho entre o real e o fantástico (PRICE, 2006). O divino era o fundamento de todos os acontecimentos da vida terrena, sendo possível evocá-los desde os mais simples motivos até as mais grandiosas causas. OTTO (2005, p. 11) diz que "nenhuma imagem do vivente é completa sem o divino", ou seja, eles não explicam a realidade como ela é, eles são a própria realidade.

Os gregos projetavam nos seus deuses todas as qualidades que eles mesmos gostariam de ter, ou seja, possuíam todas as características dos seres humanos em sua forma ideal (YALOURIS, 2003). O grande número de deuses em qualquer religião politeísta não significava que cada um deles tinha menor ou maior importância do que o outro na essência de seu significado do que no monoteísmo. O antropomorfismo também não diminuía em nada suas 
qualidades, pelo contrário, facilitavam ainda mais sua função de modelo de ser, era o homem construindo os deuses à sua imagem e semelhança (BRANDÃO, 1997). Como eles tinham a peculiaridade de poder se transformar em muitas coisas, não necessariamente tinham que ser corpóreos. O antropomorfismo foi apenas a forma escolhida por ser a mais fácil de se compreender e aceitar, mas que poderiam ser definidos simplesmente como um campo de energia, como denuncia a história onde Sêmele pede a Zeus que se mostre em todo o seu esplendor, sendo fulminada pela "luz radiante" no mesmo instante em que, relutante, o deus atendeu ao seu pedido (MAUROMATAKI, 1997).

A relação do humano com o divino era bastante próxima. A ideia do “dou-te para que me dê" não era totalmente válida para os gregos, eles não tentavam "comprar" os deuses com sacrifícios e oferendas, mas sim desenvolver um ambiente de amizade que poderia ser benéfico no futuro. Além disso, pudemos observar que possuir a mesma religião, ou seja, participar dos mesmos cerimoniais religiosos, davam às antigas cidades-estado um sentimento de unidade, e muitas vezes, quando os santuários eram localizados longe do centro urbano, serviam inclusive para determinar os limites do território desta cidade (MAUROMATAKI, 1997; PRICE, 2006).

Apesar de existirem inúmeros santuários com seus respectivos cerimoniais, não existiam muitos sacerdotes com dedicação exclusiva a eles, esta função era apenas um aspecto privilegiado de suas vidas. De acordo com PRICE (2006), eles poderiam ser homens ou mulheres, o que dependia principalmente do deus que serviam, se era essencialmente masculino ou feminino. Normalmente era esperado que a sacerdotisa fosse virgem, e que assim permanecesse enquanto estivesse servindo ao santuário. Já do homem, apenas era esperada a abstinência sexual enquanto se preparava para os festivais. 
Estes festivais frequentemente possuíam eventos atléticos, que atraiam grandes atletas daquela época, além de um enorme número de pessoas que se dirigiam ao santuário para assistir a essas competições. O prêmio era algum objeto sagrado para a região, como por exemplo, as ânforas de azeite feitas com azeitonas colhidas de oliveiras sagradas, oferecido nas Panatenaias, o grande evento realizado em Atenas. As ânforas eram também decoradas com motivos religiosos, aproximadamente 1400 delas devem ter sido entregues como prêmio durante os anos em que os festivais foram realizados, sendo que ainda hoje nos restam cerca de 300 peças inteiras ou fragmentadas, nas quais podemos observar seus desenhos e atestar seu caráter sagrado. Além disso, os vencedores também ganhavam uma coroa com ramos de oliveira, e possivelmente uma pensão perpétua de sua cidade natal (PRICE, 2006). Eventualmente, poemas eram encomendados por eles, sendo Píndaro o mais famoso dos poetas, imortalizando, através de suas Odes, os feitos dos vencedores nos principais jogos Panhelênicos.

\subsection{Fundamentação Teórica e Recorte Histórico}

Após observarmos a estreita ligação que os Jogos tinham com a mitologia, não podemos esquecer que eles estavam inseridos em um contexto histórico que foi decisivo tanto para a construção como para a fixação daquele imaginário, sem o qual eles talvez jamais pudessem ocorrer, pois como acredita ELIADE (1998, p. 7):

Antes de se tentar uma definição do fenômeno religioso, temos que saber onde procurar o 'feito' religioso em seu estado mais puro, mais próximo de sua origem. Isso é tarefa 
impossível, pois todas já pressupõem uma longa evolução histórica.

Então, para nos ajudar na desconstrução deste imaginário, teremos que primeiro ver como ele foi sendo formado durante o tempo, e quais os mecanismos que o inseriam na sociedade, para que, a partir deste ponto, possamos olhar para as sociedades que o influenciaram e tentar melhor compreendê-las. Pois, ainda seguindo ELIADE (1983a, p. 166), “o helenismo mergulha suas raízes no Egito e na Ásia, mas é a contribuição dos conquistadores que se produziu o 'milagre grego'”. E, de acordo com o mesmo autor (1998, p. 376),

Pelo simples fato de o homem tomar conhecimento de uma revelação do sagrado, esta revelação, qualquer que seja o plano em que se realize, torna-se histórica. A história intervém, desde que o homem experimenta, segundo a inspiração de suas necessidades, o sagrado.

\subsubsection{A Cultura e os Símbolos}

A história como processo, segundo JAGUARIBE (2002), teve seu início juntamente com o aparecimento das primeiras formas de cultura, no início do Período Paleolítico, dado que, desde então, o ser humano tornou-se capaz de transmitir elementos não herdados geneticamente, facilitando e até mesmo acelerando seu processo de desenvolvimento. Para ELIADE (1998, p. 320), “ $a$ história, na perspectiva da mentalidade primitiva, coincide com o mito", por isso a necessidade dessa grande volta no tempo até o momento onde a "história" se confunde com os acontecimentos míticos. Isto se torna necessário 
não para tentar chegar às suas origens, mas para melhor compreender sua estrutura e influências no desenvolvimento das sociedades da antiguidade.

O homem pré-histórico surgiu aproximadamente há três milhões de anos. Os primeiros vestígios encontrados acerca de sua existência foram utensílios feitos pelos Australopitecos, primeiro de seixos de lava erodidos pela água e de pedras apenas lascadas, sendo depois aprimoradas através do polimento, ganhando mais forma. A preservação destes vestígios se deu por estes materiais se conservarem muito melhor do que qualquer outro disponível àquela época, além das raras ossadas e objetos feitos de ossos achados em locais privilegiados de natural conservação. Somente muito tempo depois que as peças mais resistentes à deterioração pelo tempo, feitas de cerâmica ou mesmo objetos inteiros feitos deste material, encontradas com bastante frequência nas escavações, passaram a se tornar as principais lembranças destes povos da antiguidade. Por meio justamente destes vestígios arqueológicos podemos estudar e tentar compreender a evolução do ser humano através do tempo (VIALOU e VIALOU, 2005).

A principal evolução biológica encontrada foi em relação às próprias ossadas, em modificações que ocorreram na base do cérebro, alterando sua funcionalidade e interferindo diretamente no seu comportamento. VIALOU e VIALOU (2005) dizem que essa evolução morfológica e estrutural do esqueleto craniano do Homo contribuiu para um maior equilíbrio dinâmico para a posição ereta e, consequentemente, para a locomoção. Além disso, essa modificação anatômica contribuiu para o desenvolvimento da região do lobo frontal do cérebro, responsável pela interação do individuo com o mundo exterior, assim como dos sistemas de representação, como a linguagem e a arte. Portanto, podemos dizer que a verticalização da face e o desenvolvimento de novos modos de comunicação verbal deram ao homem pré-histórico uma outra forma 
de relação com o mundo exterior, direcionando sua evolução em relação às melhoras das interrelações entre os acontecimentos do mundo, e principalmente na compreensão e ligação com o meio ambiente ao qual pertence.

Uma das primeiras formas de interação do humano com a natureza veio com o temor frente aos seus mistérios. Isso, segundo ELIADE (1983c), trouxe como consequência direta uma valorização religiosa das realidades naturais. E completa dizendo que foi através da necessidade de apropriação das peculiaridades de cada entidade divina que surgiu o complexo processo de personificação.

Dessa forma, as representações podem ser entendidas como as principais relações das imagens mentais com o mundo exterior, pois, no entender de DURAND (2002), todo o pensamento humano é uma representação, se localizando no ponto de intersecção entre o imaginário e o simbólico, sendo o imaginário justamente o que dá sentido as representações humanas. Elas, portanto, são produtos diretos do imaginário humano, e, mesmo sendo representações individuais, através de meios de codificações comuns, serão compreendidas e retransmitidas ao resto do grupo. As imagens, por este motivo, por mais desgastadas que se encontrem, carregarão sempre junto com elas um sentido intrínseco à sua significação imaginária. $\mathrm{O}$ estudo da imaginação, assim como qualquer tentativa de mitologia, no sentido do termo, acaba voltando sua atenção a sua significação local e, consequentemente, para sua origem.

A evolução da estrutura cerebral foi possivelmente uma das principais colaboradoras para que a espécie Homo Sapiens produzisse os mesmos tipos de comportamentos simbólicos em todo o mundo, frutos de um mesmo órgão de percepção sensorial, ao qual, segundo VIALOU (s/d), podemos chamar de unidade antropológica. O que diferenciará uma sociedade da outra, ou mesmo 
um grupo de homens de outros, serão as diferentes variáveis culturais inerentes a cada uma delas.

A palavra cultura, em seu sentido original ainda em latim, se referia ao cultivo do solo ou ao cuidado de algo geralmente físico, que com o passar do tempo, passou também a ser cognitivo. A definição pioneira de TYLOR ${ }^{13}$, do inicio do século passado, (citado por THOMPSON 2000, p. 171), se referia a um

Conjunto inter-relacionado de crenças, costumes, formas de conhecimento, arte, etc., que são adquiridos pelos indivíduos enquanto membros de uma sociedade particular e que podem ser estudados cientificamente. Estas crenças, costumes, etc., formam um "todo complexo" que é característico de uma determinada sociedade, diferenciando essa sociedade de outros lugares e épocas diferentes.

No entanto, FERREIRA SANTOS (2004a, p. 61) amplia este conceito, entendendo-a como:

Um universo de criação, transmissão, apropriação $e$ interpretação dos bens simbólicos e suas relações.

Completando ao dizer que (p. 38);

O que caracteriza as diversas formas de cultura são os processos simbólicos envolvidos no ato criativo, assim como aqueles envolvidos em nossa capacidade de nos apropriarmos de seus conteúdos, sentidos e significados.

Considerar o mito como elemento integrante e indissociável da cultura, segundo CAMPBELL (1995, p. 368), permite afirmar que as artes, a filosofia, as

${ }^{13}$ TYLOR, E. B. Primitive Culture. Oxford: University of Oxford, 1871. 
descobertas da ciência e formas de organização sociais estão impregnadas de sentido, na medida que surgem desse círculo básico e mágico.

A mitologia tem sido interpretada pelo intelecto moderno como um primitivo e desastrado esforço para explicar o mundo da natureza (Frazer); como um produto da fantasia poética das épocas pré-históricas, mal compreendido pelas sucessivas gerações (Muller); como um repositório de instruções alegóricas, destinadas a adaptar o indivíduo ao seu grupo (Durkheim); como sonho grupal, sintomático dos impulsos arquetípicos existentes no interior das camadas profundas da psique humana (Jung); como veículo tradicional das mais profundas percepções metafísicas do homem (Coomaraswamy); e como a Revelação de Deus aos Seus filhos (a Igreja). A mitologia é tudo isso. Os vários julgamentos são determinados pelo ponto de vista dos juízes. Pois, a mitologia, quando submetida a um escrutínio que considere não o que é, mas o modo como funciona, o modo pelo qual serviu à humanidade no passado e pode servir hoje, revela-se tão sensível quanto a própria vida às obsessões e exigências do indivíduo, da raça e da época.

Segundo a obra de Eudoro de SOUZA (1995), “o homem só se sente invadido pela estranheza do mundo, quando já vive em outro que dele começa a ser" (p. 9), e é justamente neste ponto que nos deparamos com uma primeira dificuldade, pois o que seria, então, aquele mundo que já não é mais? Para este mesmo autor, "o mundo é a última e mais espantosa metamorfose de um deus", ou seja, quando aparece a tomada de consciência de uma forma primeira, em outra ele já se encontra. No entanto, um deus é origem, e origem não tem história. É nesse ponto que aparece o mito, que através do ritual representa esta origem.

Dessa forma, podemos ver que mito e cultura partilham de estreita ligação. No entender de FERREIRA SANTOS (2004b, p. 145): 
O mito é a narrativa dinâmica de imagens e símbolos que orientam as ações na articulação do passado e do presente, em direção ao futuro.

Isso nos mostra o quanto é importante o estudo correlacionado de cultura e mito para termos uma visão mais completa da sociedade em que pretendemos estudar. $\mathrm{O}$ significado que o mito carrega de maneira latente imprime e ao mesmo tempo revela a tônica do momento por que passa um indivíduo ou grupo social.

Afirma ELIADE (1989) que, ao invés de os estudiosos tratarem o mito enquanto fábula, invenção ou ficção, demonstrando um emprego na linguagem corrente bastante equivocado, passaram a aceitá-lo como ele era concebido e entendido nas sociedades arcaicas: uma história verdadeira, preciosa, por ser considerada sagrada, ao mesmo tempo, exemplar e significativa. Desde então, o mito tem sido explorado e estudado por etnólogos, sociólogos e historiadores das religiões enquanto tradição sagrada, revelação primordial e modelo exemplar. Nas sociedades em que o mito está vivo, ele fornece modelos para o comportamento humano, e por isso mesmo, confere valor à existência.

A aparente falta de lógica que por vezes apresenta em sua estrutura narrativa, muitas vezes pode dificultar seu entendimento e interpretação, sem nos darmos conta de que sua compreensão provém do universo do inconsciente (ALVARENGA, 2009). Não se trata, segundo DURAND (1964), de interpretar o mito buscando nele explicações para a origem da vida ou de reduzi-lo a manifestações do inconsciente humano, mas sim de achar o problema da expressão intrínseca ao próprio simbolizante. Ora, Durand mesmo diz que "um símbolo revela sempre, qualquer que seja o conteúdo, a unidade fundamental de varias zonas do real" (p. 73), dessa forma, temos nele uma espécie de 
“impressão digital” marcada por características únicas da sociedade na qual está inserido.

No entender de DURAND (1985) o mito se configura como um relato (discurso mítico) que dispõe em cena personagens, situações, cenários geralmente não naturais (divinos, utópicos, surréels, etc.), segmentável em reduzidas unidades semânticas denominadas de mitemas ${ }^{14}$ nas quais, de modo necessário, está investida uma crença. Para RICOEUR (1976), estes não são as frases constituintes de sua "história", mas sim "um valor opositivo ligado as várias frases individuais, que formam um feixe de relações” (p. 94). Dessa maneira elas podem ser usadas e combinadas de forma a produzir um sentido, porém, não sendo necessariamente o que o mito significa, mas que nos revela a sua estrutura. Ainda para Durand, tal relato faz funcionar uma lógica que escapa aos clássicos princípios da lógica da identidade. O mito aparece, assim, como discurso último de constituição da tensão antagonista fundamental ao "engendramento" do sentido.

De fato, usando uma boa definição de $\operatorname{ALVARENGA}(2009$, p. 9) que completa este quadro, diz ela que os mitos são

\footnotetext{
${ }^{14}$ Mitema pode ser definido, segundo Durand (1985: 253-54), como a menor unidade de discurso miticamente significativa, um 'átomo' mítico de natureza estrutural ('arquetípico' no sentido junguiano, 'esquemático' no sentido durandiano) e seu conteúdo pode ser indiferentemente um 'motivo', um 'tema', um 'cenário mítico', um 'emblema', 'uma situação dramática'. No mitema o 'verbal' domina a substantividade. E mais, desde que o mitema integra um sistema estatístico que define o mito, observa-se - como irredutivelmente a psicanálise o estabeleceu no domínio psicológico - uma dupla utilização possível desse mitema estrutural segundo os recalques, as censuras, os costumes ou ideologias atuantes numa época e num meio dados: um mitema pode se manifestar e semanticamente agir de dois modos diferentes: um modo 'patente' e um modo 'latente'. De modo patente o mitema pode se manifestar pela repetição explícita de seu ou de seus conteúdos (situações, personagens, emblemas, etc.) homólogos; e de modo latente, pela repetição de seu esquema de intencionalidade implícita, pela repetição de um esquema formal mascarado por conteúdos distanciados.
} 
O conjunto de histórias, relatados de geração a geração como forma de explicar como o mundo se fez e tudo aconteceu.

A mesma autora, concordando com Durand, diz que o mito é um "depositário de respostas aguardando perguntas", cabendo a nós formularmos corretamente as perguntas para encontrarmos o caminho para as respostas que já estão dadas, fixadas no mito desde de a sua gênese.

FERREIRA SANTOS (2004a) conclui que a principal característica das mais variadas formas de culturas são os processos simbólicos envolvidos no ato criativo, assim como aqueles envolvidos na capacidade humana de se apropriar dos conteúdos, sentidos e significados, de poder difundi-los pela comunicação e, sobretudo, de interpretá-los resultando em uma melhor compreensão do mundo, e consequentemente, de nós mesmos. Os processos simbólicos podem ser transmitidos e comunicados envolvendo a aprendizagem de auto-apropriação e interpretação, fechando e, ao mesmo tempo, ampliando o seu conceito simbólico cultural.

No entanto, quando os símbolos e significantes já estão fixados em forma de linguagem e estrutura social, não podem ser entendidos pelo seu "conteúdo" que supostamente tinham que veicular, mas sim às estruturas ideais que lhes são próprias, inseridas em relações quase-racionais (CASTORIADIS, 1999). Para RICOEUR (1976), a significação primária de um símbolo fornece os elementos para a compreensão de uma significação secundária e seus excedentes de sentidos, como que um "sentido de um sentido". Existe aí a necessidade de um manejo coerente de um sistema simbólico. CASTORIADIS (1982, p. 152) aponta que:

A sociedade constitui seu simbolismo, mas não dentro de uma liberdade total. $O$ simbolismo se crava no natural, e se 
crava ao histórico (ao que já estava lá); participa, enfim, do racional. Tudo isso faz com que surjam encadeamentos de significantes, relações entre significantes e significados, conexões e consequências, que não eram nem visadas e nem previstas. Nem livremente escolhidas, nem livremente impostas a sociedade considerada, (...) o simbolismo determina aspectos da vida da sociedade (...) cheio de interstícios e de graus de liberdade.

O ser humano está constantemente criando e tentando comunicar o que foi criado, fazendo com que o receptor crie estratégias para interpretar e buscar sentido nestas criações, apropriando para si o conteúdo transmitido não apenas de sua cultura, mas como de tantas outras (FERREIRA SANTOS, 2004c). O imaginário corresponde a exatamente essa capacidade de abstração da rede simbólica.

Conforme DURAND (2002), o imaginário é esta encruzilhada antropológica que permite esclarecer um aspecto de uma determinada ciência humana por um outro aspecto de uma outra. Para o autor, todo pensamento humano é representação, isto é, passa pelas articulações simbólicas, indicando uma continuidade no homem entre o 'imaginário' e o ‘simbólico'. O imaginário é assim esse conector necessário pelo qual se constitui toda representação humana. Existência e imaginário apresentam-se enquanto forças organizativas contraditórias, porém complementares e simultaneamente concorrentes, cabendo ainda ao imaginário a função básica de garantir uma equilibração antropológica.

DURAND (2002, p. 41) aponta que o imaginário e as grandes imagens arquetípicas produzem e são produzidos no trajeto antropológico, entendido como: 
A troca incessante que existe ao nível do imaginário entre as pulsões subjetivas e assimiladoras e as intimações objetivas que emanam do meio cósmico e social.

O trajeto antropológico é a afirmação de que, para que um simbolismo possa emergir, ele deve participar indissoluvelmente - numa espécie de contínuo vai-vem - das raízes inatas na representação do sapiens e, no outro pólo, das intimações várias do meio cósmico e social (DURAND, 1994). A lei do trajeto antropológico, tipo de uma lei sistêmica, mostra bem a complementaridade na formação do imaginário entre o estatuto das capacidades inatas do sapiens, a repartição dos arquétipos verbais em grandes estruturas 'dominantes' e seus complementos pedagógicos exigidos pela neotonia humana.

Essa concepção promove uma articulação entre o bio/psíquico e o sócio/cultural, permitindo a manifestação tanto da constância dos arquétipos, bem como da diversidade dos aspectos sócio-culturais.

Tanto a linguagem como a realidade de cada sociedade leva a formação de um imaginário social, que combinado com seu valor simbólico permite a manutenção de sua unidade cultural, moldada historicamente, e constantemente se adequando às novas situações estabelecidas, criadas ou não, mas sempre agindo como meio organizador do comportamento humano, assim como suas relações sociais. Logo, o imaginário transcende valores simbólicos e situações real-racionais, ao mesmo tempo em que existe sua significação e possui uma funcionalidade, sem a qual não existiria nem sociedade e nem cultura (CASTORIADIS, 1982).

Segundo RICOEUR (1976), o mundo é o conjunto de referências abertas pelos textos, sendo exatamente nesse sentido que poderíamos falar de "mundo grego", ou seja, temos um conjunto substancial de situações exibidas por relatos descritos daquela realidade, seja por autores que viveram naquela 
realidade, ou por outros que a estudaram e chegaram às suas conclusões. A dinâmica da interpretação vem do direito do leitor em realizá-la, com o direito do texto em produzi-la, se convergindo em uma importante luta, tendo como mediador a hermenêutica, ou seja, uma espécie de interpretação orientada pelo que está realmente escrito.

Quando nos referimos aos povos do passado, como aponta JENSEN (1998) e corroborado por ELIADE (1983a), muitos costumes e representações são passíveis de compreensão, mas há um tanto de outras ações que soam estranhas à nossa forma de ver o mundo, mas que estão de alguma forma ligadas ao contingente de imagens de quem as realizou. Como consequência disso, ao estudarmos as representações dos povos pré-históricos estamos estudando a história da própria evolução cultural do ser humano que se relaciona a sua existência na busca de respostas sobre a realidade a qual pertence e a que está criando.

A parte dos conteúdos e relações estabelecida entre o corpo e o meio se desenvolvem nas gesticulações culturais concentradas em sistemas que produzem uma imagem arquetípica, podendo ter dois caminhos, o racionalizante e o mitológico, o que nos faz voltar de novo ao início.

Conforme RUBIO (2001), anatomia biológica e psíquica são dois termos utilizados para possibilitar a compreensão de uma 'estrutura' que envolve conhecimento e sabedoria, ou seja, conhecimento sendo a instância desenvolvida dentro dos paradigmas da ciência, e sabedoria como produção da ordem do sagrado, do numinoso. Nessa perspectiva, faz parte da sabedoria ter experiências com sonhos e outras expressões da atividade inconsciente, e também com a mitologia no seu sentido mais amplo.

No entanto, conforme acredita DURAND (1964), ainda não estamos diante da verdade absoluta, o enfoque simbólico é apenas uma das muitas 
possíveis leituras que podemos fazer em relação aos episódios míticos, sendo necessária também a compreensão histórica do período ao qual desejamos estudar, para podermos estabelecer inferências e associações.

O mesmo autor (2002), diz que o mito é um sistema dinâmico de um símbolo ou de um arquétipo, sendo o mito um primeiro esboço de racionalização. E segundo suas próprias palavras, “os mitos são idéias nascente, e o imaginário é a infância da consciência” (p. 21).

O imaginário, como descrito acima, está também localizado precisamente em uma fase cultural de um determinado grupo social, e sua estrutura histórica dependerá dos arquétipos cíclicos ou progressivos, nos mostrando a impossibilidade de uma explicação evolucionista ou histórica do mito. Ou ainda, nas palavras de DURAND (2002, p. 390),

Longe de ser um produto da história, é o mito que vivifica com a sua corrente a imaginação histórica e estrutura as próprias concepções de história.

A razão, por isso, não se trata de uma evolução do mito, mas sim de um ponto de vista eventualmente mais abstrato e sofisticado pelo contexto social. A história, portanto, não explica o conteúdo mental dos arquétipos, é a própria história quem pertence ao domínio do imaginário, e em cada uma de suas fases o imaginário se encontra presente.

É nesse ponto que VERNANT (2002) define os mitos, dizendo que são de certa forma relatos aceitos, entendidos como as mais antigas formas de documentações históricas. Associado a isso, CAMPBELL (1992; 1997) sintetiza este fato dizendo que "o material do mito (...) lida com os termos que se mostram mais adequados à natureza do conhecimento da época” (p. 7), além de estar intimamente associado à sociedade no qual está inserido. $\mathrm{O}$ mesmo autor 
mostra que o desenvolvimento das representações acompanha a evolução do homem há muitos anos, e indica que em aproximadamente 600.000 a.C. no Período Paleolítico, mais precisamente no Estágio do Plesiantropo, mesma época em que se tem as primeiras evidências do uso do fogo, além do início do uso e fabricação intencional de ferramentas, têm-se indícios de que os seres humanos se apegavam a alguns objetos de forma mais racional, sem utilização clara para o cotidiano, começando uma primeira fase de contato mais claro entre o humano e a natureza.

\subsubsection{A construção do Matriarcado}

As representações pré-históricas são codificações de uma série de escolhas de modos gráficos de expressão, possuindo estreita relação simbólica com a sociedade em que esse material está inserido, isto é, com quem possui capacidade de absorver e transmitir seu conteúdo, de forma a estar em relação direta com quem a observa (ELIADE, 1983a). Além disso, o local de sua expressão não é aleatório, posto que existe íntima ligação das representações com a arquitetura natural do local escolhido, podendo os sinais serem vistos conjuntamente, isoladamente ou em uma espécie de ordem. Este tipo de organização é denominado na arqueologia de "dispositivos parietais", conceito que denomina a distribuição das representações feitas em um local como se o considerassem uma unidade, com o espaço gráfico construído baseado nas relações espaciais entre a temática das representações sobre o local escolhido (VIALOU, s/d). Sua complexidade será sempre associada ao grau de aproveitamento da arquitetura natural.

O local onde existe a arte rupestre, como são chamadas essas representações, incluindo ela própria, segundo VIALOU (2000), corresponde a 
um período de tempo vivido, com sua própria ordem cultural e rede simbólica, em um espaço limitado e por um tempo determinado. Ela, através desta consciência simbólica coletiva, reflete a identidade cultural da sociedade à qual pertenceu. A base composta de características comuns garante o valor identitário das diversas categorias iconográficas da arte rupestre, ganhando importante função na construção da identidade coletiva.

OTTE (2003) afirma que existem dezenas de milhares de formas que podem testemunhar os comportamentos simbólicos e sociais dos povos paleolíticos. No inicio, as representações simbólicas tinham o corpo humano como objeto central de valorização e a arte de ornamentação foi a mais antiga forma de arte inventada por eles. Foram também produzidos adornos e utensílios utilizados para simbolizações em sepultamentos. Para o homem primitivo, de acordo com DIEN (1966), o mundo e as forças naturais constituem uma unidade. Por isso, podemos observar que os desenhos em paredes rochosas eram predominantemente os constituídos de figurações de animais em relação aos outros, como por exemplo, o próprio corpo humano, algumas faces e simbolizações de sexo feminino, ilustrando um forte domínio do matriarcado, vítima ainda da incompreensão dos mistérios da fertilidade e total submissão às forças da natureza. O grande número de bisões contido nas representações européias é uma evidência que endossa o respeito a essas forças, já que de acordo com a estrutura idealista de LEROI-GOURHAN (1965), este animal simboliza o princípio feminino, ao contrário do cavalo, que possui ligação com o masculino.

As representações de animais, as mais numerosas, raramente não eram completas, com o animal quase sempre representado por inteiro. Podiam medir de cerca de 50 centímetros a 2 metros de comprimento, com exceção feita às gigantescas figuras da caverna francesa de Lascaux, que chegam a ter até 5 
metros de largura. Os corpos humanos frequentemente tinham o sexo bastante enfatizado, carregado geralmente de significado próprio. O sexo feminino isolado, como citado anteriormente, era mais comumente encontrado do que o masculino. Além destas, foram achadas representações feitas apenas de símbolos, sem nenhum propósito contido nelas, a não ser em sua abstração dentro do contexto da época em que foi realizada (OTTE, 2003).

Alguns sinais, ou conjunto de sinais, específicos de cada sítio rupestre, segundo a pesquisa de KERN ${ }^{15}$, citado por VIALOU (2000), determinavam a originalidade das micro-sociedades daquela época, não sendo nem narrativos, nem realistas, mas cercada de formas que possuem uma espécie de código para sua compreensão. Refletem a ideologia e aspirações de sociedades especificas, sendo elas os primeiros traços de uma linguagem gráfica ainda em elaboração. Foi através delas que se pôde chegar a evidências relacionadas com a identificação dos povoamentos e suas relações com determinado território, assim como para a compreensão daquelas sociedades primitivas e da complexidade de suas culturas. Mesmo que existam poucas ideias fundamentais em comum, a herança religiosa do paleolítico, segundo ELIADE (1983a), apresenta uma configuração bastante complexa, indicando uma possível estrutura cosmogônica em formação, ou já formada.

A predominância de representações associadas ao sexo feminino e à fertilidade como um todo pode indicar que estas figuras foram uma das primeiras evidências de um sentimento religioso, direcionadas a uma ainda inconsciente figura da Grande Mãe, que depois viriam a se transformar em pequenas estatuetas e grandes rituais.

${ }^{15}$ KERN, A. A. Sociedades Ibero-americanas: reflexões e pesquisas recentes. Porto Alegre: EDIPUCRS, 2000. 


\subsubsection{A busca pelo divino}

A história da evolução cultural, no entender de JENSEN (1998), é de certa forma a história da visão do mundo, pois se baseia no argumento de que o homem está sempre fazendo questionamentos acerca de sua existência, em busca de respostas sobre a realidade na qual está inserido e a que criou. Um exemplo disso é a ainda presente crença em forças cósmicas, diferente das manifestações da Antiguidade, mas é uma diferença pautada em uma realidade distinta, de forma que de certo modo, permanece igual.

Todos os costumes humanos se originam em algum momento da história da humanidade, e o momento exato de sua origem é uma expressão, uma atitude determinada do indivíduo frente ao meio em que vive. O ser humano só pode ter pensamentos e representações de coisas e acontecimentos que de alguma forma fazem, ou já fizeram, parte de seu contingente de imagens, e estas dependem quase que exclusivamente da cultura para ter seu significado original proposto, como descrito anteriormente. Mesmo depois, quando este costume já não possui qualquer relação com o significado original, ele continua sendo repetido. Estes momentos foram por JENSEN (1998) denominados de momento de "expressão", quando estão em relação ao ato original, e de "aplicação", quando o sentido lógico já se perdeu.

Os cultos são frutos diretos dessas formas de expressão, pois são baseados em uma forma mítica de conhecer o mundo. A íntima conexão entre mito e culto constitui uma característica essencial da maioria das formas primitivas de religião, pois é através dos cultos que os homens revivem o ato criador. Desta forma, o conhecimento mítico do mundo influencia de modo decisivo todas as formas de vida dos seres humanos, já que de acordo com o pensamento de RICOEUR (1976), se nenhum mito narrasse como as coisas 
chegaram a ser como são, ou se não existissem rituais que renovassem seu vigor, o sagrado permaneceria não revelado.

A religião enquanto expressão central da vida espiritual dos povos, segundo JENSEN (1998), pode ser vista apenas como um resultado de falsos processos de pensamentos, ou seja, é uma tentativa de explicação lógica das formas incompreensíveis das manifestações da natureza, se tornando uma apropriação do caráter divino da realidade. A procedência da vida baseada em ideias mitológicas era satisfatoriamente aceita pelos povos da Antiguidade, pois tinham nelas uma única possível explicação para sua existência. São exemplos disso o totemismo, que representa a relação dos homens "atuais" com seus antepassados divinos, sendo responsável pelo impulso para a constituição da sociedade humana. Sua grande importância se dava no elo explícito que se estabelecia entre homens e deuses quase na mesma categoria. Outro aspecto é o politeísmo, que precede a ideia de um único deus que criou o mundo e que segue seu reinado, os quais juntamente com outros seres divinos do tempo primordial, por suas ações, as coisas do mundo são tais as quais são. Aos poucos, como acredita KANT (1959), conforme o homem foi tomando maior conhecimento do mundo, se apropriando de muitos mistérios outrora atribuído a deuses, as ideias mitológicas foram sendo abandonadas, passando para o mundo das fantasias, sendo incabível aceitá-las como verdades.

Durante a minha pesquisa de mestrado (MACHADO, 2006), foi escolhido um trecho da obra de TUCIDIDES (2001) - "História da Guerra do Peloponeso", ilustrando que esse tipo de pensamento já havia sido desenvolvido na Grécia ao menos desde o século V a.C., época em que ele vivia. Diz em sua obra: 
À luz da evidência apresentada até agora, todavia, ninguém erraria se mantivesse o ponto de vista de que os fatos na Antiguidade foram muito próximos de como descrevi, não dando muito crédito, de um lado, às versões que os poetas cantaram, adornando e amplificando os seus temas, e de outro considerando que os logógrafos ${ }^{16}$ compuseram suas obras mais com a intenção de agradar aos ouvidos que de dizer a verdade uma vez que suas estórias não podem ser verificadas, e eles em sua maioria enveredaram, com o passar do tempo, para a região da fábula, perdendo, assim, a credibilidade (Hist. 1, 21).

Na época em que Tucidides viveu (aproximadamente entre 460 a 400 a.C.), os helenos já sofriam a influência de alguns filósofos pré-socráticos, incluindo seu conterrâneo, o próprio Sócrates, que nasceu em Atenas em 470 ou 469 a.C., em um momento em que acontecia o grande impulso para a quebra da antiga forma de pensamento. Foi o período das vitórias gregas sobre os persas nas Batalhas de Maratona (490 a.C.) e Salamina (480 a.C.), além da mítica vitória dos espartanos na Batalha das Termópilas (479 a.C.), levando a Grécia a um grande período de euforia, fazendo com que os homens acreditassem mais neles próprios do que nos deuses, deixando de obedecer a uma ordem cósmica preestabelecida. Sócrates encontrou, nesse ambiente, condições ideais para desenvolver seu pensamento baseado não nos deuses, mas nos homens, depositando na razão as soluções para os problemas da natureza, abandonando a visão mítica do mundo (SOUZA, 1999; CAMPBELL, 2004; PESSANHA, 1999).

CÍCERO (1995) mostra em sua clássica obra "Da Republica”, como foi importante essa transformação ao relatar o terror e a superstição envolvendo um exército romano após o acontecimento de um eclipse lunar. E pela

\footnotetext{
${ }^{16}$ Os logógrafos eram uma espécie de profissionais que proferiam relatos em forma de prosa, misturando os eventos reais (factuais) com as histórias proveniente da mitologia (que não pode ser provada), recebendo, por este motivo, as criticas de Tucídides.
} 
imposição da razão, ao tomar conhecimento do fato e de sua funcionalidade, livrou os soldados da crença de um mau agouro, ajudando positivamente no desenrolar da batalha.

Esses tipos de crenças ou superstições não surgiram ao acaso, foram desenvolvidas ao longo do tempo com relação direta ao desenvolvimento cultural dos próprios seres humanos que, segundo CAMPBELL (1992), pode ser vista como uma unidade, sendo criada seguindo um mesmo fundo de motivos mitológicos, interpretados e organizados de modos diferentes seguindo as necessidades locais, porém, fiéis às características da sociedade a qual está inserido. Cabe à mitologia a função de suprir de maneira satisfatória as necessidades da mente humana, garantindo um sentido à vida com profundidade e extensão diretamente relacionadas à sua mitologia local. Esta possui um caráter progressivo, unida à faixa histórica da sociedade em que pertence, evoluindo conjuntamente com seus habitantes.

CAMPBELL (2004) sintetiza de forma bastante clara em quatro funções os aspectos da mitologia: a primeira era de trazer à tona e sustentar um sentido de espanto diante dos mistérios da existência; depois, de oferecer uma cosmologia que sustentará e será sustentada por aquele sentido de espanto diante do mistério de uma presença e da presença de um mistério; a terceira era de garantir a ordem social vigente, para integrar organicamente o indivíduo em seu grupo; e por fim a quarta, de introduzir o indivíduo na ordem das realidades de sua própria psique, orientando-a para seu próprio enriquecimento e realização espiritual.

Mas, de acordo com SOUZA (1995), não devemos olhar o mito apenas como uma "biografia dos deuses", mas sim como uma maneira de se falar do mundo e também dos homens. O Mito também nos fala dos deuses, mas não de sua história, falam de suas figurações e de seu processo de constituição no 
cosmos, de forma a nos contar não somente sobre os mitos deste mundo, mas também sobre os homens deste mundo. Só indiretamente chegamos aos deuses através do "aparecer do mundo com seus homens e dos homens com seu mundo", sendo ele o meio pelo qual "os deuses saem do seu oculto reinar" (p. 102), não sendo possível chegar a isso apenas falando da descrição de suas particularidades e funções. Podemos, então, visualizar um triângulo, onde temos "Símbolo", "Homem" e "Mundo" em cada um de seus vértices, como um esquema da colocação deles nessa estrutura imaginária. Portanto, quando o mundo aparece, os deuses desaparecem, dando ao mito sua característica de relato, personificada através do rito, tornando "o nosso presente (...), presente daquele passado” (p. 86).

Continuando com as ideias de SOUZA (1995, p. 101),

De cada vez que um deus acena de dentro de um homem que se apossou, este homem canta um mito significado por um rito, e representa um rito significante de um mito.

De acordo com o autor, essas seriam as formas elementares da religião. De forma geral, qualquer coisa pode ser um símbolo quando sacralizada, transparecendo o "ser-origem" a que se diz significante, se fazendo por meio dos deuses, a forma e o conteúdo de uma mensagem.

Portanto, a volta à origem do mundo, ao início, é fundamental para se estabelecer as prioridades de um sistema especifico de qualquer religião. Nenhuma sociedade consegue viver em mundo que não compreende, e a mitologia ocupa este espaço, ao estabelecer um contato entre o real e o imaginário, dando vida aos deuses. Essa ligação do humano com o divino, na oposição entre o profano na direção ao sagrado, é o que se denomina de religião. 
$\mathrm{Na}$ antiga cultura grega as tentativas de mitografia histórica muitas vezes fracassam pelo fato de os mitos serem, na maioria, pré-helênicos, e como acredita CABRAL (2004a), jamais será possível dizer com precisão quais entidades míticas surgiram primeiro, principalmente pelo fato de os gregos não verem problemas em aceitar deuses estrangeiros. Além do mais, tinham admiração pelas religiões egípcias, judaicas e as hindus, pois sabiam que, em sua essência, representavam as suas civilizações.

Por isso, de acordo com JAGUARIBE (2002), temos que procurar criar métodos críticos na tentativa de relatar o passado, e tentar identificar e analisar os principais fatores e condições que exerceram alguma influência sobre um processo histórico. E como diz o mesmo autor (p. 42),

O processo histórico é a sequência, no tempo e no espaço, das ações humanas que afetam as condições que influenciam, de qualquer forma, outras ações humanas.

É por este motivo que se torna de fundamental importância nos apropriarmos das principais características das duas principais civilizações que influenciaram no surgimento e no desenvolvimento da antiga cultura helênica.

\subsubsection{A influência indo-européia}

Vimos anteriormente que as primeiras construções mitológicas surgiram durante o Período Paleolítico, no qual foram encontradas ferramentas que pareciam não ter utilidade no cotidiano, podendo ser interpretadas como utensílios para cerimoniais, com um fim sagrado. Os primeiros rituais religiosos, segundo CAMPBELL (1992) e JAGUARIBE (2002), podem ser atribuídos ao Homem de Neandertal (200.000 a.C. a 75.000 a.C./25.000 a.C.), onde já naquela 
época havia o domínio do fogo e o uso de vestimentas. Além disso, as evidências mostram rituais predominantemente voltados à caça, assim como a existência de sepultamentos cerimoniais, com os corpos colocados em posição fetal, podendo indicar a introdução de rituais religiosos, não existindo evidências anteriores a isso de que estes atos poderiam já estar sendo realizados. Para ELIADE (1983a; 1998), a colocação do cadáver em forma embrionária e muitas vezes voltados para o leste, alinhado com o curso do sol, tem por trás a ideia de fazer com que a "Terra-mãe" possa dá-lo a luz uma segunda vez. Com essa consciência da mortalidade, diferenciando o vivo do não-vivo, iniciou-se de maneira decisiva a construção de conceitos entre o humano e o divino, direcionando o modo de ser da humanidade desde então.

De acordo com os mesmos autores, durante o Período do Homem de Cro-Magnon, especialmente os Aurinhacenses e Salutreanos (30.000 a 10.000 a.C.), começaram a aparecer alusões aos mistérios da fertilidade de forma bastante clara, como demonstrado pelas estatuetas femininas com seios e quadris bem enfatizados, pertencentes àqueles povos. Isso pode ter ocorrido, pois de acordo com ELIADE (1983a), o domínio das primeiras técnicas de agricultura, resultou em uma situação existencial inédita, servindo de estímulo para a criação de valores que modificaram o "universo espiritual" do homem pré-Neolítico. Os mistérios do ciclo morte-renascimento, fenômeno empírico ao ritmo da vegetação, se tornaria a justificativa religiosa de seus comportamentos, focados na renovação periódica do mundo. No Período Neolítico, que se inicia em cerca de 7.500 a.C., tem-se o início dos primeiros assentamentos, principalmente facilitados pelo desenvolvimento da agricultura e da criação de gado, promovendo o surgimento de aldeias auto-suficientes. Foi nesta época que as primeiras estatuetas femininas começaram a ser fabricadas na região do Mar Egeu. A inexistência de evidências de fortificações pode indicar que estas 
aldeias tiveram, no inicio, um crescimento pacífico, favorecendo um rápido desenvolvimento cultural com gradativo aumento do acumulo de riquezas.

As civilizações da Mesopotâmia, as primeiras do mundo, já apresentavam fortificações, pois estavam cercadas de povos guerreiros que mantinham um estilo de vida nômade. Alguns deles se aproximavam dos centros urbanos apenas com o intuito de saqueá-los, e outros tentavam se fundir com a população civilizada para permanecer como seus novos senhores. Por isso, foram também os primeiros a organizar exércitos permanentes para a defesa do território, assim como para o ataque a outros povos, porém ainda estavam fortemente associados a rituais religiosos, sendo a vitória ou a derrota um resultado de uma decisão coletiva dos deuses, da mesma forma como agiriam os gregos, séculos mais tarde (JAGUARIBE, 2002).

Se, por um lado, durante o Período Neolítico começaram a aparecer vestígios de ideias conscientes de oferendas aos Deuses, associados a uma consequente estruturação de motivos mitológicos, foi exatamente nesta fase que se iniciou o conflito entre o poder masculino da conquista contra os mistérios da fertilidade feminina. Foi no final do quarto milênio a.C. que se desenvolveram técnicas para se chegar aos cerca de $1100^{\circ} \mathrm{C}$ necessários para fundir o Cobre e o Zinco, dando origem às primeiras ligas metálicas para a formação do Bronze. $\mathrm{O}$ ser humano já não estava mais totalmente submisso às forças da natureza, já conseguia compreender coisas que antes o assustava e, em meio a essa realidade, o mito da serpente, criado por diversas culturas e que representava as forças obscuras da natureza, passou a ser atacado por figuras humanas, podendo ser visto em alguns exemplos, como na Bíblia, que narra a luta entre Jeová e o Leviatã; na poesia grega, que descreve a batalha entre Zeus e Tifão; e na Índia, entre Indra a Vritra. Em todos os casos, era a serpente o monstro derrotado, símbolo do matriarcado, destruída pelo ímpeto guerreiro do patriarcado 
(CAMPBELL, 1992). ELIADE (1983a) diz que essa transição não se deu de forma simples e direta, pois os minérios eram extraídos do interior da terra, sendo por isso, ainda relacionados com a natureza, possuindo seus cultos específicos.

Segundo JAGUARIBE (2002), por volta de 3.000 a.C., durante a Idade de Bronze, ao mesmo tempo em que as primeiras vilas e formas iniciais de governo iam se desenvolvendo nos arredores do Egeu, o imperialismo começava a ganhar força nas Cidades-Estados de quase todo o território Europeu e Asiático como hoje o conhecemos. Partindo de uma região localizada aproximadamente no sul da Rússia, ao norte do Mar Negro entre o Cáucaso e os Cárpatos, os povos Indo-europeus, antes pacíficos, tiveram uma grande transformação em seu modo de ser com o desenvolvimento das técnicas de fabricação e uso do Bronze, favorecendo a manufatura de utensílios e armas mais resistentes, motivando-os a conquistas de outros territórios, marcando este período com diversas formas de guerra.

De acordo com o mesmo autor, uma destas guerras, ocorrida em aproximadamente 1.950 a.C., envolveu um destes povos, os Aqueus, com os primeiros habitantes da Península do Peloponeso, que por lá haviam se estabelecido em cerca de 3.500 a.C., mas que pouco se desenvolveram. Provavelmente por conta de algum distúrbio climático na região onde viviam, os Aqueus migraram para a região do Peloponeso em procura de terras mais férteis e, consequentemente, entraram em conflito com os habitantes das pequenas tribos locais, denominados de Pelasgos. Estes, acuados frente aos invasores acabaram fugindo para o sul, encontrando refúgio em algumas ilhas do Mar Egeu, e principalmente em Creta se unindo aos moradores locais, que por ser uma ilha, estava longe das disputas territoriais continentais. Como consequência disso, encontraram lá condições ideais para dar prosseguimento aos antigos 
cultos à Deusa-Mãe, gestadora, nutridora e sepultadora, longe da influência dos invasores que se estabeleceram no continente, onde era mais valorizada a figura do homem guerreiro, capaz de defender seu território e de realizar grandes feitos nos campos de batalha. Os cultos eram realizados tanto ao ar livre como em edifícios preparados especialmente para esse fim. Os corpos de seus mortos eram colocados em posição fetal em urnas de barro, depositados em túmulos coletivos. Este fato pode ser uma indicação da continuidade na crença em alguma força divina, precursora da família dos deuses Olímpicos.

Esta fase da história grega, compreendida entre 2.500 a 1.900 a.C., caracterizada pela chegada e estabelecimento das antigas civilizações da Idade do Bronze, foi por CAMPBELL (2004) denominada de Fase Heládica Antiga, momento em que surgiu a ideia de Zeus, um deus supremo vindo do alto. A fase seguinte, compreendida entre 1.900 a 1.600 a.C., foi a Fase Heládica Média, sendo caracterizada pela violenta invasão dos Jônios que, expulsando os Aqueus, se fixaram na Grécia continental, desenvolvendo posteriormente a civilização Micênica. De 1.600 a 1.500 a.C., tivemos a Fase Heládica Tardia I, que foi o momento em que a civilização cretense, isolada das disputas da Grécia continental, associado a uma influência da já desenvolvida civilização Mesopotâmica e Egípcia, encontrou condições ótimas de se desenvolver, se tornando a mais avançada da época, como podemos ver através das construções de grandes palácios, em especial o de Cnossos, sendo inclusive, responsável pela criação e desenvolvimento das principais personagens da religião grega.

Creta tinha, segundo JAGUARIBE (2001), sérias limitações no seu sistema agrícola. Eram os reis cretenses que regulavam esta frágil economia com a estabilização da produção, da distribuição, consumo e exportação das mercadorias. Foi o medo de catástrofes naturais que os fez ter um profundo respeito pelas forças elementares da natureza, principalmente aquelas 
relacionadas à fertilidade. Além disso, os reis minoicos possuíam características sacerdotais, mas, ao contrário do que acontecia no Egito, não deixavam monumentos à sua homenagem. Importante ressaltar que, segundo VIVANTE (1999), na antiga Mesopotâmia um dos cultos mais importantes era à deusa Ishtar, a deusa do amor e da sexualidade, e no Levante (costa leste do Mediterrâneo), Athirat, esposa de El, era tida como responsável pela criação, características que também podemos observar nas deusas helênicas anteriores a geração Olímpica.

Posteriormente, por volta de 1.450 a.C. durante a Fase Heládica Tardia II, os Jônios invadiram a Grécia continental e se fixaram em Micenas. Eram caracterizados pela sua força militar, possuindo uma estrutura social baseada em uma unidade familiar doméstica (oikos), semelhante a encontrada nas obras de Homero, cujas poesias teriam se originado durante esta época, entre os séculos XV e XII a.C. (FINLEY, 1980). Por ter essa característica, os valores de fertilidade essencialmente femininos foram perdendo importância em relação à crescente imagem do homem guerreiro, capaz de defender esta primeira forma de comunidade. Nessa época, iniciaram o intercâmbio com os minóicos, gerando uma grande transformação no campo mitológico. O encontro entre essas duas civilizações, embora na prática não tenha se dado de forma pacifica, no campo da mitologia ela ocorreu de forma harmoniosa, fazendo com que os deuses originais indo-europeus predominantemente patriarcais dos invasores se unissem com as deusas de tradição local, culminando com a formação da grande família Olímpica, visto não só pela aproximação entre o feminino com o masculino, mas também no modelo da guerra dos Titãs, onde as forças elementares acabaram sendo derrotadas em conjunto por deuses antropomórficos e por humanos. Essa batalha, segundo CAMPBELL (1994), representou a luta entre dois aspectos da psiquê humana e ocorreu em um momento crítico de sua história, quando os 
símbolos masculinos heróicos claros e racionais superavam os misteriosos e obscuros símbolos femininos encravados no interior de seu próprio inconsciente.

Esta situação também pode ser vista com frequência durante o trajeto da jornada mitológica do herói, onde vemos constantemente a interferência de uma heroína, sendo a figura feminina ao mesmo tempo a criadora e receptáculo concreto do sentido originador da ação, que abdica simbolicamente do direito de reinar, para aceitar a renovação trazida pelo masculino heróico (DURAND, 1964; ALVARENGA, 2009).

$\mathrm{Na}$ ilha de Creta, a representação desses valores permaneceu visível em um dos cerimoniais mais conhecidos daquela cultura, que era o salto sobre o touro, uma atividade que consistia em saltar de frente para o animal, segurando em seus chifres para que estes servissem para dar impulso para um posterior salto sobre seu lombo, terminando com a saída para o solo. Independentemente de se tratar de um espetáculo bem treinado ou de um desafio real, pelo fato do touro ser um símbolo de força e fertilidade, representava o enfrentamento e superação do humano frente à natureza (DIEN, 1966). As figuras, segundo estudo de REESE e RICKERSON (2000), mostram homens e mulheres participando deste ritual, inclusive existe um copo de ouro pertencente à civilização Minóica, datado em cerca de 1.900 a.C., localizado no Museu Arqueológico de Atenas, mostrando uma garota lutando contra um touro.

CAMPBELL (2004) chama esta reformulação das tradições locais, adaptadas aos interesses de uma nova cultura, como vimos no caso entre as civilizações Minóica e Micênica, de "difamação mitológica", que acaba tendo como consequência a formação de uma nova estrutura de pensamento, validando os costumes e sistemas de crenças de uma nova ordem social. A imagem prende o indivíduo em seu sistema familiar de valores, historicamente condicionado. Portanto, como afirma ELIADE (1969, p. 17), 
Os mitos, os símbolos e os ritos exprimem, em planos diferentes e com os meios que lhes são próprios, um sistema complexo de afirmações coerentes sobre a realidade última das coisas.

A civilização micênica, embora possuísse uma estrutura social menos desenvolvida do que a minóica, era superior militarmente e com isso acabou por conquistar os cretenses, ao mesmo tempo em que ocorreu um dos raros casos em que os vencidos deixaram decisiva influência cultural aos invasores, vencedores, fazendo sobreviver muitos dos cultos em honra a deusas e relacionados à fertilidade.

Foi logo após esta fase, durante o século XII a.C., que ocorreu a última leva de invasores, representada pelos Dórios, que, encontrando uma Grécia bastante fragilizada pelas constantes batalhas do Império Micênico frente aos povos que habitavam a região do Mar Egeu, denominados de "povos do mar", com relativa facilidade levou os já desorganizados locais a fugirem para a Ásia Menor, deixando a Grécia em uma espécie de caos cultural, com o desaparecimento de quase toda a população local, diminuindo substancialmente o comercio interno, prejudicando o intercâmbio entre os povos sobreviventes, levando a um progresso esparso e vagaroso, iniciando-se a denominada "Idade das Trevas helênica”. Segundo BRANDÃO (1996), a arte minóica entrou em decadência, a língua grega deixou de ser escrita e os ritos masculinos ganharam mais força em virtude do comportamento guerreiro dos novos invasores, e conforme acredita MUNGUIA (1992), foi dessa união cultural da ultima leva de invasores, os Dórios, com o que restou após o declínio e quase desaparecimento da civilização micênica, que deu origem ao povo grego da antiguidade tal como 
o conhecemos, sendo este, inclusive, o período épico em que teriam vivido os heróis de Homero.

Segundo HARTOG (2004), os pelasgos, habitantes primordiais da Península do Peloponeso, logicamente já possuíam suas crenças em deuses "organizadores do Universo", e que os invasores Indo-europeus teriam trazido seus nomes e principais características, nascendo assim o politeísmo grego. Homero e Hesíodo teriam apenas organizado o panteão por inteiro, assim como seus deveres e atribuições.

De acordo com JAGUARIBE (2001), essa constante pressão que os bárbaros $^{17}$, geralmente de caráter nômade, exerciam sobre as populações estabelecidas em determinado território, teve um importante papel para o desenvolvimento destas civilizações, pois representavam ao mesmo tempo um desafio destrutivo e uma fonte de renovação, situação a qual o mesmo autor denominou de "Síndrome barbárie-civilização". Ou seja, se por um lado poderiam destruir toda uma comunidade, estimulavam mesmo que de maneira impensada o desenvolvimento da força de seus opositores. No caso dos invasores da região do Peloponeso, eles carregavam, sobretudo, uma característica que foi fundamental para o desenvolvimento da sociedade grega e para as práticas atléticas: eram geralmente regulados por um ethos ${ }^{18}$ heróico, dando ao vitorioso o poder de decidir entre a vida ou a morte do derrotado, impondo uma espécie de código de coragem, fazendo-os ter plena devoção à causa defendida.

MAY (2002) diz que as tribos Indo-européias mais do norte, que inclusive é um retrato de uma das peculiaridades da mitologia celta, tinham por característica não lutar apenas com o objetivo de ganhar, mas sim de lutar

\footnotetext{
17 Estamos aqui utilizando o termo "bárbaro" nos referindo a qualquer invasor não pertencente à linha construtora de determinada civilização, e não apenas de acordo com sua origem clássica atribuída.

${ }^{18}$ Entendemos por ethos o caráter, o conjunto de hábitos e ações de determinada sociedade, garantindo-lhe uma identidade.
} 
porque tem que fazê-lo, porque a própria vida é uma guerra cujo principal inimigo, a morte, é invencível e sempre acaba nos deixando de joelhos. Sua alegria está em saber que nunca será totalmente derrotado, já que ele vai ser de qualquer forma derrotado com a morte. Simplesmente descansará no outro mundo antes de retornar, pronto para mais um novo combate. Isso fazia com que eles aceitassem os riscos pessoais de uma batalha, o que os transformava em excelentes guerreiros, desprezando a morte como algo terrível, ao mesmo tempo em que legitimavam a fama heróica com a imortalidade da memória, característica essa que foi a tônica dos heróis das grandes epopeias.

A Grécia, portanto, passava por um momento bastante delicado em sua história, contudo, ainda de acordo com JAGUARIBE (2001, p. 206),

Se tudo parecia destruído, a poesia épica sustentou os resíduos sobreviventes, atuando como um fator importante na formação da civilização grega, sendo o único elo de ligação entre este passado.

As histórias contadas na mitologia, de acordo com VERNANT (2000), não se extinguem em seu texto poético. Possuem diversas significações, comportando variantes múltiplas que o narrador tem a sua disposição, escolhendo as melhores opções de acordo com as circunstâncias de seu público ou de sua preferência, podendo acrescentar, cortar ou modificar o que lhe parecer mais conveniente.

Por esse motivo, quando se encontra na mitologia da Antiguidade uma história já definida em seu texto, se quisermos compreendê-la corretamente, temos que abrir a pesquisa à sua complexa rede de significados, de forma a ter claros os passos de seu desenvolvimento, inerente a evolução cultural da sociedade à qual está inserida. No entender de Vernant, é necessário estudar 
primeiro as diversas versões do mesmo tema, por menores que sejam, para depois ver os relatos míticos próximos e distantes e até mesmo histórias pertencentes a saberes distintos dessa mesma cultura, como por exemplo, a literatura científica, a política e a filosófica, e por fim, às variações mais ou menos similares de civilizações distantes para compreendermos influências e apropriações.

As manifestações atléticas, como não poderia ser diferente, logicamente sofreram influências de outros povos para o seu início, mas foram únicas na Grécia. As práticas atléticas realizadas no oriente próximo asiático e no Egito não possuíam essencialmente nada em comum com as gregas, a não ser o natural desejo de deixar o corpo forte e saudável, não deixando de ter, neste aspecto, uma importante influência. De acordo com GARDINER (1971), as primeiras atividades relacionadas à cultura grega deste tipo que conhecemos e que foram realizadas em grandes eventos vêm de Creta, foi o já citado salto sobre o Touro, prática esta que ficou imortalizada pelas belas figuras encontradas no palácio de Cnossos, e que ainda hoje podem ser vistas no museu de Heraklion, atual capital daquela ilha. Seus traços sofreram nítida influência dos antigos egípcios, como podemos ver através das semelhanças encontradas entre ela e algumas figuras desenhadas nos sarcófagos de Beni-Hassan, que continha os túmulos dos Faraós do Reino Médio (entre aproximadamente 2.100 a 1.600 a.C.). ${ }^{19}$ Ela era realizada provavelmente apenas pelos membros da aristocracia, como indicam os braceletes vistos nas representações desta atividade.

GARDINER (1971) fala que os gregos estão em débito com a antiga civilização minóica em relação ao seu sistema atlético e festivais atléticos, mas que, no entanto, estes devem sua influência aos antigos egípcios. Em Creta,

\footnotetext{
${ }^{19}$ Existia ainda a influência da Índia pré-védica, onde, segundo ELIADE (1998), existiam jogos com touros datando de cerca de 2500 a.C., porém, esta análise ultrapassa o escopo deste texto.
} 
podemos ver figuras de um vaso de Hagia Triada representando um boxeador, além de corrida a pé e salto em distância com alteres. As já mencionadas representações do salto sobre o Touro datam de cerca de 2.000 a.C., e foram as mais preferidas nas representações. Podemos ver homens e mulheres participando desta atividade, sendo distinguidos pela diferença da cor da pele, assim como faziam os egípcios.

O pugilismo e a luta também eram conhecidos, e devem ter vindo de origem egípcia ou etrusca, dado que evidências apontam para a sua prática no país africano anteriormente ao desenvolvimento da cultura minoica, e de prática regular na península itálica anterior ao século VIII $a$.C.. Um afresco achado na ilha grega de Thera (Santorini) mostra dois jovens lutadores em posição conhecida do boxe atual, assim como proteção para as mãos, praticando o pugilato, como o era denominado. YALOURIS (2003), corroborado por GARDINER (1971), acredita que a postura desenhada demonstra técnica e treinamento para a prática, pois não seria natural para uma pessoa destreinada realizar naturalmente aqueles movimentos, devendo ter havido algum sistema específico para seu desenvolvimento, mas que permanece desconhecido, devendo, assim como no desenvolvimento da luta egípcia, ter encontrado nos preparativos militares "a primeira oportunidade de aparecimento do espírito atlético” (p. 13). A mais antiga representação de sua prática é de um vaso cipriota datado de 1.100 a.C., que se encontra hoje no British Museum de Londres. A mais antiga evidencia de uma corrida é de um vaso micênico encontrado no Chipre, datado de cerca de XIII $a$.C., e de uma corrida de carros desde o século XVI $a . C$..

No entanto, um cuidado deve ser tomado, pois não há qualquer referência de competições em Creta. As lutas de pugilato tinham o caráter de espetáculo, sendo realizada provavelmente por profissionais ou escravos, nada 
existindo em comum com a prática atlética homérica, onde os praticantes tinham em sua realização uma espécie de atividade prazerosa. GARDINER (1971) acredita que não há nenhuma diferença na essência entre as práticas atléticas de Creta com Roma, completando ao dizer que não foi somente graças aos cretenses que os helênicos de um período posterior herdaram o gosto pelas práticas atléticas, não sendo, portanto, em Creta o seu berço. Mesmo que a prática do salto sobre o Touro tenha feito parte de um cerimonial religioso com significado próprio, não podemos fazer qualquer tipo de inferência com os grandes Jogos Públicos realizados a partir do século VIII a.C. em solo grego.

Uma grande dificuldade existe, especialmente para os gregos da antiguidade, em aceitar que o desenvolvimento da cultura helênica tenha sofrido influência de outros povos, pois isso implicaria em aceitar que os antigos mestres de sua cultura fossem bárbaros!

Nada poderia ser mais cruel para eles do que aceitar isso, mesmo que as semelhanças entre os grandes jogos celebrados pelas duas culturas no passado denunciem isso. Tucidides diz que "o mundo grego antigo vivia de modo análogo ao mundo bárbaro atual” (Hist. I, 6, 6). Se bem que ele mesmo diz que na época da guerra de Tróia não existia ainda a separação entre gregos e bárbaros, não existindo ainda a unidade grega (Hist. I, 3, 3). Esta unidade não era formada por aqueles que viviam no mesmo território, pois não se sabia até onde iam as suas fronteiras. O que determinava ser ou não ser grego, segundo Heródoto, era o fato de possuírem o "mesmo sangue, a mesma língua, santuários, sacrifícios e costumes comuns" (Hist. VIII, 144).

Portanto, além dos povos Indo-europeus, que tiveram decisiva influência sobre o desenvolvimento da civilização helênica, o Egito também esteve presente neste processo, dado que na época da $12^{\mathrm{a}}$ Dinastia egípcia, durante o Reino Médio, por volta 2.050 a 1.800 a.C., havia, segundo 
JAGUARIBE (2002), um intenso comércio entre eles com a emergente civilização cretense, que se prolongou durante o domínio dos Hicsos sobre o Egito entre 1.730 a 1.570 a.C. e depois se aproximando dos micênicos durante a reestruturação cultural egípcia durante o Reino Novo até aproximadamente 1.380 a.C. no reinado de Amenhotep IV. Como a Ilha de Creta teve grande importância para a construção da cultura grega, se torna fundamental compreender a estrutura mitológica egípcia para poder melhor entender suas influências e associações, principalmente se somado ao fato de que, segundo RICOEUR (1976), o Egito teria sido o berço da sabedoria religiosa. Heródoto acreditava, sem nenhum problema em aceitá-lo, que os egípcios foram precursores da cultura helênica, não sendo à toa que dedicou o mais longo livro de sua História a este país que "encerra ele mais maravilhas do que qualquer outro país”. Para ele, não havia dúvida de que os egípcios foram os primeiros a regular a relação entre os homens e os deuses, e que a religião grega possuía origem egípcia.

\subsubsection{A influência egípcia}

Existe uma grande dificuldade em interpretar os processos formativos do antigo Egito em virtude da ausência de um livro sagrado com informações padrão, assim como a existência de divergências entre grupos de deidades nos diversos povoados que viviam ao longo do Nilo (BAINES, 2007). As evidências apontam, segundo SILVERMAN (2002), que anterior a 3.000 a.C. existia um cuidado com o sepultamento, podendo indicar crenças funerárias. Estes, por sua vez, são a prova mais contundente da existência de ideias religiosas incrustada no imaginário daquele povo, mas, ao mesmo tempo, estas atitudes de enfrentamento da morte, segundo LOPEZ (1993), não nos ensinam nada sobre 
as práticas religiosas do cotidiano dos vivos. Outro fator de dificuldade é que existiam muitos e diferentes povos no antigo Vale do Nilo, e como ainda estavam pouco desenvolvidos, eram incapazes de chegar a explicações lógicas para os mistérios da existência, tendo cada uma um foco de pensamento distinto. Porém, com o tempo, estas ideias foram se juntando, estruturando e dando forma à complexa e grandiosa família dos deuses egípcios. As constantes preocupações em serem fieis à sua forma original, mesmo com constantes mudanças principalmente políticas, fez com que durante os seus mais de três mil anos de história sua cultura permanecesse estável, fazendo com que eles sempre tivessem de forma bastante vivida a noção de quem eles eram. Por isso, a aproximação de sua cosmovisão, juntamente com seus conceitos intelectuais, segundo JAGUARIBE (2002), pode nos ajudar a melhor compreender a sua cultura.

A volta à origem do mundo, ao início, é fundamental para quem deseja estabelecer as prioridades de um sistema específico de qualquer religião, que procura descrever uma realidade fora do alcance físico do ser humano (LESKO, 2002; SHAFER, 2002). No Egito, isso não se deu de forma diferente.

Para os egípcios, a mitologia não era uma coleção de textos, mas sim uma linguagem, o que se torna fundamental para explicar porque as ações dos deuses podiam ser alteradas, expandidas e mesmo reaparecer com outros protagonistas sem inconsistências aparentes. O mito, de certa maneira, é antes do aparecimento da filosofia grega, a única maneira de exprimir ideias sobre o cosmos ou sobre necessidades da alma humana, que para os antigos egípcios, era dividida em três principais componentes - $K a$, o seu principio vital, $B a$, o fator psíquico e $A k$, a sua manifestação depois da morte (CLARK, s/d.; JAGUARIBE, 2002). 
CLARK (s/d.) diz que o número de símbolos básicos no antigo Egito era razoavelmente pequeno, com alguns deles encontrando paralelo em outras culturas. Outros, porém, são peculiares àquele país, como, por exemplo, o olho divino e a coluna Djed. Não é o símbolo em si, mas sim a ideia que ele carrega que o torna significativo. Eles são, por sua própria natureza, focalizadores de emoções ou especulações da imaginação, pertencem ao mundo dos mitos mesmo os que tenham origem profana. As combinações de diferentes símbolos não são casuais, entretanto, as regras que governam seu uso são pouco compreendidas. Talvez até mesmo para eles isso não fosse claro, dado que os receptores destes símbolos poderiam se resumir a elite social da época, e sua transmissão por via oral para o resto da população são incertos por falta de fontes seguras.

Para ARAUJO (2000, p. 42),

As inscrições e imagens históricas do Egito Antigo não narram eventos reais, em vez disso, proporcionam o ingresso em um mundo solene e ritualístico que não contém elementos de sorte e acaso. Os egípcios não possuíam historiografia como a conhecemos, nenhuma narrativa do passado. Em sua visão, o passado só interessava na medida em que era também o presente e poderia ser o futuro.

Como veremos, muitas das histórias míticas se sobrepõem com base no denominado principio da intertextualidade, que o mesmo autor o define como "todo texto se constrói como um mosaico de citações, todo texto é absorção e transformação de outro texto" (p. 40).

Os deuses egípcios foram criados a partir de um deus primordial, responsável inclusive pela sua própria criação (SILVERMAN, 2000). Conforme os antigos habitantes do Vale do Nilo iam tomando maior conhecimento do 
mundo, a outros deuses iam sendo atribuídos estas múltiplas facetas, por isso, foi aos poucos sendo organizada uma grande sociedade dos deuses, com sua estrutura social bem parecida com a dos humanos, e que foi muito bem documentada.

O principio básico da cosmologia egípcia, segundo CLARK (s/d.) e HART (1992), eram as águas primordiais, personificadas por $\mathrm{Nu}$, (ou Nun), que é a entidade primitiva simbolizada por um oceano ilimitado de água inerte imersa em trevas. Representava o Caos, a "não existência" antes da criação, muito embora nunca tenha deixado de existir. Mesmo depois ela era tida como a fronteira do mundo exterior, existindo sempre o temor de que esta poderia romper o céu e inundar a terra. Das águas, veio Atun (ou Aton), o antigo deus Sol que mais tarde seria unido a Rá, e posteriormente em Heliópolis, "tomando seu falo em seus punhos", e gerou os gêmeos Chu e Tefnut, que representavam, respectivamente, o ar e a umidade. Este ato de Atun nos mostra que dentro deste existe o protótipo de todas as forças cósmicas e dos seres divinos. Este casal deu origem à quarta geração divina, um outro casal, que representava a terra e o céu, denominados respectivamente de Geb e Nut, que por fim, deram origem à quinta geração divina, a mais representada através das histórias, consistida por Isis, Osíris, Seth e Neftis, com os dois primeiros gerando Hórus, talvez o mais representativo de todos os deuses para a estrutura social egípcia.

Pela cosmogonia Menfita, Atun passou, segundo CLARK (s/d.) e ARAUJO (2000), a ser o progenitor do casal primordial Chu e Tefnut, aparecendo Ptah como o portador do supremo poder. HART (1992) diz que, no Livro dos Mortos e em alguns documentos da era de Ramsés (por volta de 1.290 a.C.), existia referencias a Ptah como sendo responsável pela criação de deuses, do Sol, do amadurecimento dos vegetais e dos próprios homens, através da argila. Ele deu vida aos deuses mais antigos por meio de seu coração e língua, 
sendo sua presença sentida através destes, pois tudo o que se sente vai para o coração, e então é externado pela língua. Foi provavelmente da tentativa de se pensar sobre a natureza de Ptah que surgiu a cosmogonia menfita, como podemos ver na Pedra de Shabaka, cujo nome é em homenagem ao Faraó que teria ordenado a transcrição do texto que estava em um papiro em avançado estado de deterioração, para uma pedra de granito, se conservando em bom estado até a atualidade, podendo ser vista no British Museum de Londres.

Já no mito de criação de Hermópolis, Amon era uma das forças elementares. Cada deus era uma imagem projetada de Amon, e três deuses em particular formavam sua unidade - Rá era sua face, Ptah seu corpo, e o próprio Amon sua identidade oculta. LANGE (1964) e JAGUARIBE (2002), acreditam que essa aparente confusão na mitologia egípcia se deu pelas diferenças regionais na nomenclatura de alguns princípios, que na essência, eram os mesmos. A aparente "unificação" dos deuses - Amon, Rá, Ptah - fez com que os povos se tornassem, de certa maneira, iguais. Para isso, os antigos textos eram, então, "corrigidos" mas sem enfraquecer seu tom vigoroso original. Os seus próprios deuses eram frequentemente vistos nos dos estrangeiros, pois apesar da diferença de nome, eles sabiam que o mesmo principio supremo reinava sobre todas as nações, como, por exemplo, Amon-Zeus-Jupiter, IsisAfrodite-Venus, Hórus-Apolo e Ártemis-Bastit se reconhecem como irmãos e se confundem.

Voltando a cosmogonia de Menfis, Ptah/Rá/Atun, os senhores originais, retiraram-se para além da criação. A cronologia se segue com estes transmitindo seu poder a Chu que por sua vez transmitiu-o para Geb, a terra. Este passou o trono para seu herdeiro Osíris, que governou o Egito em uma época de prosperidade, ensinando técnicas de agricultura e domesticação de animais aos homens, mas logo foi assassinado por seu irmão Seth, representante 
das forças do Caos, e temporariamente se tornou o senhor do Egito. A Osíris coube governar no mundo dos mortos. Após ser assassinado, suas irmãs - Isis, que também era sua esposa, e Neftis, esposa de Seth - partiram em busca de seu corpo, e após encontrá-lo, conseguiram através da magia por um breve período revivê-lo, porém, tempo suficiente para que Isis engravidasse deste, dando à luz posteriormente a Hórus, o deus Falcão, legítimo sucessor do trono egípcio, que o conquistou não sem antes disputá-lo longamente com Seth, como consta em uma história denominada de "A contenda entre Seth e Hórus", gravada no Papiro Chester Beatty I, do século XII a.C., de autoria desconhecida (ARAUJO, 2000).

Os antigos egípcios, segundo ASSMANN (2001), viam a morte como algo terrível, e construíram um mecanismo de defesa baseado principalmente nesta passagem da história de Osíris que, consequentemente, fundamentou o pensamento imaginário daquela sociedade. Para HART (1992), não era seu governo terreno que tinha o maior significado, mas sim o milagre de sua ressurreição, oferecendo a esperança de continuidade da existência no mundo inferior. Sua ideia surge aproximadamente entre 3.000 e 2.400 a.C. e, segundo CLARK (s/d.), foi a mais vivida e mais complexa realização do imaginário egípcio. Ele foi o símbolo do sofredor com sua morte, mas ao mesmo tempo é todo o poder de renascimento e fertilidade do mundo, é o poder germinativo das plantas e da reprodução dos animais e seres humanos. É juntamente a morte e a fonte de toda a vida, é a representação cósmica do ciclo entre morte renascimento. ARAUJO (2000) acredita que era exatamente essa a simbolização do Faraó, que sendo o criador, oculto, onisciente, previdente, compreensivo e justo, era a imagem do deus neste mundo, e por isso, trazia esperança de renovação do mundo, incorporava o passado, realizava novos feitos e gerava exposições idealizadoras de como o mundo deve ser. 
$\mathrm{Na}$ teologia tebana, o deus Cnum possui um pouco dessa representação, pois é o único que possui ligação com os seres humanos, ele é o símbolo da fertilidade do mundo natural, sendo associado a um deus das cataratas, que alimenta o rio Nilo, de fundamental importância para aquela sociedade. Da mesma forma o escaravelho se tornou um animal-símbolo bastante representativo para os antigos egípcios por representar esse ciclo de continuidade, pois segundo LANGE (1964), a fêmea escaravelho bota seu ovo em suas fezes, depositando-o em uma cavidade preparada para isso, e depois a recobre de terra. Por acreditar na existência apenas de escaravelhos machos, esse ovo que se fecundava representava o nascimento de outro macho, sendo uma espécie de prolongamento de sua própria existência, tal como a alma que escapa da múmia, alcançando o céu ou o Sol, que renasce a cada dia.

No que se refere a este conflito entre valores matriarcais e patriarcais, o antigo Egito é um caso a parte. Mesmo que tivessem possuídos muitos deuses centrais em virtude da constante troca de poderes entre os diversos povos que habitavam as margens do Nilo, nenhuma deusa chegou a este posto. Não existiu nenhuma personalidade feminina associada a criação, elas eram geralmente associadas ao amor e ao prazer, sendo as principais Hathor e Bastet. De acordo com ELIADE (1998), por uma questão de ordem gramatical, a palavra céu sendo do gênero feminino, este era representado por uma deusa, Nut, enquanto sua oposição, a terra, por um deus, Geb.

Exemplo disso, podemos ver nas histórias contadas naquela época. ARAUJO (2000) nos mostra em uma historia chamada "A separação das águas" (Papiro Berlim, inicio do Reino Novo) um Faraó que pede para que "tragam vinte mulheres belas de corpo, com seios firmes e que não tenham sido abertas pelo parto" (p. 67), e que remem em seu lago particular com o intuito de o distrair, enquanto ele fica admirando seus belos corpos. Da mesma forma, 
na história dos "Dois irmãos" (Papiro d'Orbiney, Reino Novo) a mesma referência a um corpo belo é feita - "a mais bela de corpo que qualquer mulher em todo o país, pois a semente de cada deus nela estava" (p. 88), mostrando que a busca por esse ideal possa ter existido naquela época. Talvez por isso a dança no antigo Egito fosse bastante valorizada, tanto como forma de lazer como em rituais, e eram as mulheres que as executavam. Era corriqueiro que garotas com essa habilidade se tornassem uma espécie de profissionais, com seus serviços sendo prestados em banquetes e festas, contudo, nada nos resta de referências a treinos ou notas coreográficas (WATTERSON, 1998).

As mulheres, em geral, tinham liberdade de agir na sociedade sem pedir permissão para o seu marido ou pai, sendo um possível reflexo do sistema monárquico egípcio, onde a Rainha frequentemente desempenhava importante parte no governo e até mesmo na guerra. Com isso, segundo WATTERSON (1998), elas possuíam direitos iguais aos dos homens de sua mesma classe social, mesmo que ficassem voltadas predominantemente para a esfera doméstica enquanto os homens ficavam para a pública. Uma interessante evidência deste modo de vida é a cor da representação dos corpos nos afrescos, sendo o da mulher mais amarelo, enquanto o do homem tendia ao vermelhomarrom, podendo indicar o grau de exposição ao sol, e consequentemente, da exposição à vida pública.

Essa tendência é vista no pouquíssimo número de mulheres que tiveram alguma participação fora da esfera doméstica, influenciando no curso da história egípcia. De todos os mais de quinhentos governantes divididos entre as trinta dinastias (a primeira teve inicio em 3.100 a.C. e a última terminou em 343 a.C.), apenas quatro foram mulheres. Segundo WATTERSON (1998), a primeira Rainha foi Nitocris, a última do Reino Antigo, tendo se suicidado em 2.180 a.C.. A segunda Rainha foi Sobekneferu (1.790 a.C.) que da mesma forma 
foi a ultima de uma era, denominado de Reino Médio. Hatshepsut foi em 1.490 a.C. a terceira Rainha e a quarta foi Twosret, em 1.216 a.C.. Após o período das dinastias, que teve fim em 343 a.C., o Egito ficou sob domínio Persa até 332 a.C. quando Alexandre, o Grande, anexou-o ao seu império. Após sua morte, como não tinha herdeiros, o Império foi dividido entre seus generais. Em 304 a.C. Ptolomeu se tornou Rei do Egito, iniciando a ultima dinastia egípcia. A mais ilustre figura desta geração foi a Rainha Cleópatra VII, que ascendeu ao trono aos dezessete anos em 51 a.C., e com sua enorme inteligência política conseguiu através de ligações com Roma, mesmo que por pouco tempo, a levar o Egito de novo a sonhar com a prosperidade.

As características dos deuses egípcios garantiam-lhes elementos de poder e fertilidade. Ser senhor do mundo dos mortos, ou senhor do subterrâneo, tornou Osíris o espírito do vir a ser. LANGE (1964) diz que para os egípcios, tudo na existência terrestre estava em função do "outro mundo", como se fosse a eternidade da vida terrestre. O subterrâneo podia ser um limo ou um inferno, mas também era fonte de vida nova. Quando o Sol se põe no horizonte, ilumina todas as formas que devem estar no mundo inferior, que pertencem ao passado ou até mesmo ao futuro. Como exercício de imaginação, é uma jornada ao interior da mente e uma tentativa de penetração na realidade que subjaz a esse fenômeno. A tentação de povoar as trevas com os mortos atrai quase todas as culturas, haja vista as obras de Homero e Virgilio. Para CLARK (s/d.), corroborado por ELIADE (1983d), Osíris podia ser tanto Hades enquanto senhor do mundo dos mortos, quanto Dionísio, na condição de libertador da alma humana.

As grandes construções egípcias foram exatamente a materialização dessa ordem de pensamento. HERÓDOTO (2001, II, 35) em sua clássica obra introduz ao leitor sobre sua passagem por este país, ao dizer: 
Estender-me-ei mais no que concerne ao Egito, por encerrar ele mais maravilhas do que qualquer outro país; e não existe lugar onde se vejam tantas obras admiráveis, não havendo palavras que possam descrevê-las.

LANGE (1964) acredita que a imagem cruel geralmente atribuída ao processo das construções se deve ao racionalismo greco-romano procurando a compreensão para os objetos, que no fundo foram erguidos pela fé, tal como as grandes catedrais da Idade Média, sendo o monumento eterno ao seu soberano.

Outra forma bastante peculiar que os povos da antiguidade tinham para manifestar sua relação com os poderes divinos eram os rituais transcendentes, muitas vezes realizados através das práticas atléticas, que no Egito, assim como tantas outras manifestações da vida, eram de alguma forma relacionadas à religião.

Como diz TOUNY e WENIG (1969), a data de referência para o inicio dos jogos regulares na Grécia Antiga foi em 776 a.C., mas antes disso, o Egito já possuía mais de dois mil anos de história, nos quais possuiu um grande império que se desenvolveu, floresceu e teve seu declínio. Assim como os gregos, os egípcios possuíam treinamentos para várias práticas atléticas, além de também fazer parte de rituais. Não existem, porém, evidências de que havia um sistema de educação pelo esporte como o conhecemos hoje, assim como pelas atividades atléticas, nem mesmo referências à palavra "esporte". Todas as práticas eram direcionadas essencialmente para fins militares ou para dar uma maior condição atlética ao Faraó e para membros de famílias importantes. DIEN (1966, p. 104) completa dizendo que: 
sua escola de Educação Física ao lugar da eterna beleza, nenhum feito consagrado aos deuses, tal como nos Jogos Olímpicos.

No entanto, Heródoto (II, 91) mais uma vez nos presta um serviço e faz a descrição de jogos atléticos em honra a Perseu, realizados na cidade de Quémis, mas que esta era a única em todo o Egito que eles eram celebrados. O autor aponta que os habitantes desta cidade acreditavam que de tempos em tempos o herói aparecia no país e lá deixava suas sandálias, o que significava sinal de prosperidade. Essa aparição nada mais era do que uma espécie de volta à casa, já que acreditavam que ele era natural daquela cidade e que quando ainda criança viajou para a Grécia. Voltou pela primeira vez ao Egito para cortar a cabeça de Medusa, única mortal das três Górgonas, que estaria na Líbia, e quando passou por Quémis, já conhecia o nome da cidade por intermédio de sua mãe, e ordenou aos seus habitantes, que começassem a celebrar jogos gímnicos. Mas isso era exceção e não podemos transferir essa realidade para todo o território egípcio.

TOUNY e WENIG (1969) fazem um bom levantamento das práticas atléticas no Egito Antigo, a começar pela Luta, cuja representação mais antiga vem do sarcófago de Ptah-Hotep, da $5^{\text {a }}$ Dinastia (cerca de 2.470-2.320 a.C.), que era a mais popular e provavelmente a mais treinada para fins militares. No sarcófago de Ramsés III (1.194 a 1.163 a.C.), encontra-se representado um evento de luta entre egípcios e estrangeiros, sendo interessante a ênfase na demonstração de sua superioridade, estão representadas também a figura do Faraó e de outras pessoas importantes. Além da luta, uma espécie de boxe, sem luvas de proteção também podem ser vistas, e existem bastantes representações de duelos de espadas, com figuras de lutas com uma ou duas espadas. Heródoto (II, 63), descreve uma luta não exatamente de espadas, mas de "bastonadas", se 
tratando de um evento festivo em honra do deus da guerra, reconhecido como sendo Ares pelo historiador.

Não eram apenas as lutas que existiam como exercícios físicos, o tiro com arco também foi bastante praticado, sendo inclusive a representação hieroglífica de um soldado, tendo até competições descritas. Na história "Memórias de Sanchet", descrita por ARAUJO (2000, p. 111), podemos ver que a noção de treinamento e do exercício com determinada finalidade existia de forma bastante clara, em determinada parte da narrativa, o autor coloca que,

Um campeão sem igual (...) disse que queria bater-se comigo (...). Durante a noite retesei meu arco, atirei minhas flechas, pratiquei com meu punhal e poli minhas armas.

Além da luta, uma das mais antigas formas de exercício físico praticado no Egito, outras atividades não militares, porém, utilitárias, eram também realizadas, como a natação, na qual um estilo bem parecido com o do nado crawl pode ser visto, e também o remo e a corrida a pé, que inclusive possuía um evento oficial simbolizando a renovação do poder do Faraó. Nas tumbas do Antigo e Novo Império pode ser vista a representação de um jogo que era uma espécie de simbolização de um combate naval, no qual um individuo tenta subir no barco do outro ou derrubar seu adversário na água (GARDINER, 1971).

Nos sarcófagos do Antigo Império, existiam muitas representações de crianças, predominantemente homens, fazendo exercícios ou brincando em algumas espécies de jogos, enquanto no Médio Império elas desaparecem, dando lugar aos jovens e mulheres. Voltando à tumba de Ptah-Hotep, podemos ver crianças realizando uma brincadeira onde o objetivo era saltar mais alto. As atividades atléticas desenvolvidas pelas mulheres tinham o objetivo de explorar 
suas possibilidades do corpo, como os exercícios gímnicos, por exemplo, como a realização de "pontes" e outros movimentos acrobáticos, que eram especialmente importantes, principalmente para as que possuíam alguma participação nos cultos e tinham que por ordem destes, realizar movimentos que chamassem a atenção. Além destes, foi representado também uma espécie de jogo com bolas, se assemelhando a uma espécie de malabarismo, ou simplesmente de arremesso e recepção. Para os homens, o levantamento de cargas pesadas era bem valorizado, representando sinal de virilidade, como podemos ver em diversas representações, e na história dos "Dois irmãos", quando um homem se vangloria de estar levando "o peso de três sacos de cevada e dois de trigo", totalizando aproximadamente $280 \mathrm{~kg}$ (ARAUJO, 2000, p. 84).

No antigo Egito, o ponto de ligação dos deuses com os humanos se dava através do Faraó, este era com frequência descrito como quem agia como um deus especifico, ou como semelhante a uma divindade especifica. Essa identidade passava a ser usada em associações a muitas divindades de maneira a ligar o Faraó ao panteão por inteiro. Havia, durante o Novo Império, um esforço consciente para igualar o rei com as forças do mundo divino. A grande literatura propagandista, que chamavam a atenção para os direitos de um Faraó ao trono, pode ser uma evidencia implícita de que o povo não estava totalmente inconsciente da origem humana de seu soberano (SILVERMAN, 2002). ELIADE (1998) completa dizendo que o Faraó não conquistava seu poder através de uma prova heróica, mas através de seu poder como chefe supremo. O autor acredita que isso era uma degeneração de um mito heróico-iniciático em um detrimento político-social.

O culto ao Faraó simbolizava a renovação da força criadora do mundo presente em seu momento original, e por isso, era certo ao morrer, o soberano 
era identificado com Osíris, o Rei dos mortos, e também a Rá, porém, alguns alcançavam tamanha popularidade que possuíam seus cultos separados, e passavam a desempenhar um papel de intermediário entre o povo e as divindades (ELIADE, 1983a). O Rei, portanto, atuava nos dois mundos, ao contrario dos deuses, que estavam presos ao mundo divino, não aparecendo a não ser em representações. Os Reis, segundo KANTOROWICZ (1998), tinham essa peculiaridade de ser um individuo divino agindo em meio a humanidade sem, no entanto, tornar-se um deus. Sempre houve essa reciprocidade entre eles, os Reis ao realizarem os cultos aos deuses, estes, em troca, lhes concediam sucesso e prosperidade. Os próprios rituais de iniciação indicavam essa ligação, o novo Rei era associado a Hórus depois da morte de seu pai (Osíris, e também Rá), na sucessão do mundo (BAINES, 2002).

Resultado disso foi que como vimos, em todas as fases do desenvolvimento do Antigo Egito, e bem descrito por CRUZ-URIBE (1994), o Faraó ocupava uma posição central na dinâmica social, o que se refletia também no imaginário daquela sociedade, colocando-o da mesma forma em posição privilegiada de ligação do humano com o divino, o que fez com que as possibilidades de transcendência se focassem em sua figura, não dando espaço para a população geral. Exemplo disso, e fazendo uma associação com as práticas atléticas, era que da mesma forma como alguns deuses eram representados segurando um arco na mão, assim o era o Faraó, podendo ser visto frequentemente em cima de um carro com o arco nas mãos. A caça esportiva, por esse motivo, era uma atividade estritamente elitista e bastante praticada, se caçavam predominantemente pássaros, mas não com arco e flecha, e sim com uma espécie de lança. Existia desde a antiguidade egípcia a caça ritualística do Hipopótamo, na qual o Faraó com um arpão, partia sozinho à caça deste animal, que por representar o Caos, simbolizava o seu domínio pelo soberano. 
O Inicio da dessacralização do poder do Faraó assim como a diminuição de sua autoridade durante o final do governo dos Ramsés, de acordo com JAGUARIBE (2002), fez com que essa estrutura social perdesse força, sendo como consequência um dos principais fatores para a decadência da civilização egípcia.

A proximidade entre as ideias religiosas dos egípcios e dos gregos, embora provavelmente fossem sentidas por todos naquela época, foi marcada por Alexandre, o Grande, que após sua conquista do Egito, decidiu construir uma cidade que abrigasse os dois tipos de rituais conjuntamente, nascendo assim a cidade de Alexandria no norte do Egito (VRETTOS, 2005), sendo berço de muitas inovações tecnológicas e casa da maior biblioteca do mundo antigo.

No que se refere às práticas atléticas, entretanto, foram notáveis as diferenças entre as duas, podendo ser explicadas principalmente pelas características sociais distintas de ambas, uma vez que no Egito a figura centralizadora do Faraó não abria espaço para que pessoas não pertencentes a realeza tivessem alguma espécie de atividade transcendente, quase o inverso do que acontecia na Grécia. No entanto, segundo GARDINER (1971), não há evidências de que as atividades físicas sejam exclusivas às classes mais altas, a existência de espécies de profissionais em determinadas atividades, indica que eles teriam um costume de assistir aos espetáculos dos especialistas, sem, contudo, existir referências a competições organizadas.

Era essa a realidade que os minóicos encontravam quando realizavam encontros comerciais, políticos ou mesmo sociais com os egípcios. Possuíam inúmeras semelhanças entre si, como podemos observar na arquitetura, em afrescos e em objetos de cerâmica, apontando para uma substancial influencia cultural para um povo que foi a semente da civilização helênica. 


\section{CONSIDERAÇÕES FINAIS}

Ao nos propormos tentar achar pistas que nos indicassem como se formou a trilha que ligou os antigos rituais às forças elementares da natureza aos grandes Jogos Públicos da Grécia antiga, outros tantos caminhos com origens distintas surgiram, que por mais que cruzassem aquele eu estava disposto a traçar, me levavam para longe do meu objetivo. Saber trilhá-los e desvendar cada curva que os caminhos nos apresenta, foi um prazeroso desafio que, por isso mesmo, fez perder-nos do rumo original com relativa facilidade.

Tomando o cuidado para não cair nestas armadilhas, partimos do pressuposto que estes primeiros rituais, embora "reais", tinham suas significações pautadas em elementos do imaginário que transcendiam a realidade, se fixando em sua mitologia local. Por este motivo, vimos que todas as ações arquetípicas foram iniciadas em um tempo sagrado primordial, que está fora do período cronológico, se inserindo em um momento mítico atemporal. A busca, portanto, se daria em achar como a mitologia poderia influenciar na realidade, ao mesmo tempo em que esta reforçaria seus ideais.

Os primeiros rituais, como pudemos observar, eram direcionados às forças da natureza que respondiam pela continuidade do mundo, em especial as relacionadas aos mistérios da fertilidade. Por isso, eles, no início, eram direcionados às figuras femininas, como ficou evidente desde o princípio, com os motivos das pinturas rupestres, as formas exageradas das pequenas estatuetas e, sobretudo, as inspirações que movimentavam os diversos cerimoniais. Apesar de o divino ser "sentido" na natureza e na vida cotidiana de maneira até mesmo generalizada, eram nesses rituais que a ligação com os deuses eram feitas de forma mais direta, como os gregos bem o demonstraram através do mito do sacrifício de Prometeu. 
É importante termos isso em mente, pois este é um dos principais motivos que ajudaram as práticas atléticas a achar neles um ambiente favorável para o seu desenvolvimento. Porém, este processo necessitou de um tempo para se formar e amadurecer.

$\mathrm{Na}$ Grécia, seu início se deu com a chegada das primeiras tribos indoeuropéias que se estabeleceram em seu território, trazendo com eles as ideias de uma Deusa-mãe, que se juntou com as já estabelecidas formas de deusas que existiam na região do Egeu, reforçando esta imagem. Mais tarde, com as levas de invasores que chegaram na Península do Peloponeso, outras ideias eram trazidas, e a principal delas era a da valorização do herói e do homem guerreiro, essencialmente masculino, fazendo com que as ideias femininas fossem perdendo espaço, mas não seu valor e sua importância.

Ora, o simples fato de os cerimoniais associados aos Jogos continuarem sendo realizados, mesmo em um período posterior, onde a ordem patriarcal parece já ter se estabelecido naquela sociedade, é uma boa evidência da continuidade da existência dos valores femininos. Devemos aqui lembrar que os principais Jogos devem sua origem a algum herói que os teria instituído no passado ou como agradecimento aos deuses por algum feito especial, ou como uma espécie de compensação por um ato cometido, que aos deuses teria ofendido. Porém, por trás dessa exaltação aos feitos do herói, ao invés de os vencedores ganharem algum elemento de valor, que simbolizasse a força ou a audácia do guerreiro, o prêmio pelos atletas alcançado era algo que os relacionavam com o sagrado para a região na qual o cerimonial era ocorrido.

Vejamos. Em Olímpia e em Atenas, os prêmios eram respectivamente a coroa de oliveira e uma ânfora de azeite, relacionados aos valores de fertilidade associados à árvore. Em Delfos, a coroa de louro recebida pelos vencedores remetia à história do amor que Apolo sentia pela ninfa Dafne, sendo 
o amor, a força de união entre os pares, fundamento da fertilidade. Tanto em Corinto como em Neméia, cujas competições eram de caráter fúnebre, o prêmio alcançado era a coroa de aipo, cuja associação telúrica da planta não se remetia apenas à sepultura, mas também a outras propriedades da terra, como por exemplo, mais uma vez, a de fertilidade.

Essa constante atribuição à fertilidade não era exclusividade dos gregos, vimos que os fundamentos da estrutura social egípcia, que legitimava o poder do Faraó, colocando-o como a principal, se não única, ligação entre o humano com o divino, estavam também relacionados a este fenômeno, como pudemos ver na história da morte de Osíris e nascimento de Hórus.

Portanto, a associação de um dos mais importantes fundamentos cósmicos aos heróis, atribuindo-lhes propriedades tidas como divinas, vai de acordo ao que Hesíodo estruturou em sua cosmogonia, colocando-os em um patamar elevado de existência, estando mais próximos dos deuses. Homero reforça esta tese ao deixar bem claro em suas obras o papel dos deuses no desenrolar dos principais acontecimentos do cotidiano. Nada de importante acontecia sem suas efetivas interferências, e eram justamente os heróis quem realizava os feitos mais importantes.

É aqui que aparecem as práticas atléticas. Logicamente elas já existiam e eram bem praticadas antes de serem incluídas nos cerimoniais, como demonstram evidências encontradas tanto no Egito como em algumas ilhas do Mar Egeu, além das descrições de Homero na Ilíada e na Odisséia. Como ficou demonstrado durante o texto, foi nos preparativos militares que as práticas atléticas tiveram a primeira oportunidade de aparecer, sendo usadas como recurso nos campos de batalha, da mesma forma como foram descritas em muitas histórias da mitologia, ao narrar lutas de heróis com criaturas 
monstruosas. Porém, Homero nos mostrou que elas poderiam também ser realizadas de forma espontânea, assim como pertencentes a funerais.

Ou seja, mesmo que seja impossível determinar quando e onde as práticas atléticas surgiram, podemos dizer que era certo que elas existiam e faziam parte do cotidiano daquele povo naquela época. Então, não soa entranho que os sacerdotes daqueles antigos rituais tivessem escolhido uma competição atlética para determinar quem seria incumbido de concluir o cerimonial. Se nada de importante acontecia sem a interferência dos deuses, era natural que os vencedores de cada competição venciam, porque assim estava determinado pelo seu destino, tornando-os heróis, e como tal, escolhido dos deuses. Com isso, além de buscar a re-atualização do gesto sagrado realizado na origem, procurando dar continuidade ao mundo tal como eles o conheciam, os cerimoniais ao mesmo tempo re-atualizavam a ação dos heróis em um momento mítico, que se confundia com a realidade. Seu caráter transcendente, presente por quase todo o tempo em que os Jogos foram realizados, é a melhor evidência de que isso realmente acontecia.

Mesmo que as práticas atléticas realizadas no Egito, em Creta, e em outras ilhas ao redor da Península do Peloponeso não tenham diretamente nenhuma relação com a instituição dos grandes Jogos Pan-helênicos, como apontou Gardiner, são a elas que devemos a "fecundação" da semente da qual nasceria a ideia da inclusão dos eventos atléticos nos cerimoniais religiosos, fazendo com que sua história regrida ao campo da mitologia.

Então, não há duvidas que os Jogos tiveram seu inicio e esplendor pautados em uma realidade que transcendia o mundo material, avançando naquele em que vivemos. No entanto, indo de acordo com as ideias de ELIADE (1998), inicia-se, a partir disso, um começo. Cria-se a história e uma série de 
acontecimentos "dotados de um sentido bem diferente da sequência dos gestos automáticos sem significação” (p. 321).

Os Jogos se tornam a materialização histórica desta estrutura mitológica, e os heróis, além de serem a consolidação desta imagem, são ao mesmo tempo quem proporciona um caráter de humanidade a um cerimonial divino. No momento em que aparece com importância o registro dos vencedores, a história finalmente se sobrepõe ao mito. 


\section{REFERÊNCIAS}

ALVARENGA, M. Z. Édipo, um herói sem proteção divina: a saga dos Labdácias. São Paulo: Casa do Psicólogo, 2009.

ARAUJO, E. Escrito para a eternidade: a literatura no Egito Faraônico. São Paulo: Imprensa Oficial do Estado, 2000.

ASSMANN, J. Rites et au-delá de la mort. Munich: C. H. Beck, 2001.

BAINES, J. Sociedade, moralidade e práticas religiosas. In: SHAFER, B, E. (Org) As religiões no Egito Antigo: deuses, mitos e rituais domésticos. São Paulo: Nova Alexandria, 2002.

BAINES, J. Egyptian myth and discourse: Myth, Gods, and the early written and iconography record. Journal of Near Eastern studies. v. 50, n. 2, p. 81-105, 2007.

BERTON, H. Temples et architectures sacrées: introduction a la notion de "Centre Spirituel". Clermond Ferrand: SEREST, 1990.

BRANDÃO, J. Mitologia grega. Petrópolis: Vozes, 1996. v.1.

. Petrópolis: Vozes, 1997. v.2.

Petrópolis: Vozes, 1998. v.3.

CABRAL, L. A. M. (Trad.). O Hino Homérico a Apolo. Campinas: Editora da Unicamp, 2004a.

Os Jogos Olímpicos na Grécia Antiga. São Paulo: Odysseus, 2004b.

CAMPBELl, J. As máscaras de Deus: mitologia primitiva. São Paulo: Palas Athenas, 1992. 1994.

As máscaras de Deus: mitologia oriental. São Paulo: Palas Athenas,

O herói de mil faces. São Paulo: Cultrix/Pensamento, 1995. 

1997.

As transformações do mito através do tempo. São Paulo: Cultura, As máscaras de Deus: mitologia ocidental. São Paulo: Palas Athenas, 2004.

CAMPOS, H. (Trad.). A Ilíada, de Homero. 5. ed. São Paulo: ARX, 2003. v. 1. . (Trad.). A Ilíada, de Homero. 3. ed. São Paulo: ARX, 2002. v. 2.

CARVAlHO, A. P. (Trad.). A Odisséia, de Homero. São Paulo: Nova Cultural, 2002.

CASTORIADIS, C. A Instituição Imaginária da Sociedade. Rio de Janeiro: Paz e terra, 1982.

Feito e a Ser Feito: as Encruzilhadas do Labirinto. Rio de Janeiro: DP\&A, 1999.

CHRISTOPOUlOS, G. A. The Olympic Games in Ancient Greece. Athens: Ekdotike Athenon, 2003.

CICERO, M. T. Da República. Bauru: Edipro, 1995.

CLARK, T. B. Símbolos e mitos do Antigo Egito. São Paulo: Hemus, s/d.

COULANGES, F. A Cidade Antiga. São Paulo: EDAMERIS, 1961.

CRUZ-URIBE, E. A model for the political structure of the Ancient Egypt. In: For his $K a$ : Essays offered in memory of Klaus Baer. p. 49-53. SAOC 55. The Oriental Institute. Chicago: University of Chicago Press,1994.

DIEL, P. O simbolismo na mitologia grega. São Paulo: Attar, 1991.

DIEN, C. Historia de los Deportes. Barcelona: Luis de Caralt, 1966. v.1.

DURAND, G. A imaginação simbólica. Lisboa: Edições 70, 1964. 
Sobre a exploração do Imaginário, seu vocabulário, métodos e aplicações transdisciplinares: mito, mitanálise e mitocrítica. Revista da Faculdade de Educação (USP). Trad. Prof. Dr. José Carlos de Paulo Carvalho. V. 11, n. 1/2, p. 243-273, 1985.

L'imaginaire. Essai sur les sciences et la philosophie de l'image. Paris, Hatir. Trad. Prof. Dr. José Carlos de Paulo Carvalho, e revisão técnica do Prof. Dr. Marcos Ferreira Santos, para fins exclusivamente didáticos no CICE/FEUSP. 1994.

As estruturas antropológicas do Imaginário. São Paulo: Martins Fontes, 2002.

DURANTEZ, C. Olímpia e los Juegos Olímpicos antiguos. Madrid: Delegacion Nacional de Educacion Física e Deportes, Comitê Olímpico Espanhol, 1979.

ELIADE, M. O mito do eterno retorno. Lisboa: Edições 70, 1969.

História das crenças e das idéias religiosas. t.1, v.1. Rio de Janeiro: Zahar, 1983a.

. Rio de Janeiro: Zahar, 1983b. t.1, v.2.

. Rio de Janeiro: Zahar, 1983c. t.2, v.1.

Rio de Janeiro: Zahar, 1983d. t.2, v.2.

Aspectos do mito. Lisboa: Edições 70, 1989.

Tratado de história das religiões. São Paulo: Martins Fontes, 1998.

FERREIRA SANTOS, M. Crepusculário: conferências sobre mitohermenêutica e educação em Euskada. São Paulo: Zouk, 2004a.

A sacralidade do texto em culturas orais. Dialogo: revista do ensino religioso. V.9, n.35, p. 14-18, 2004b.

- Cultura imaterial e processos simbólicos. Revista do Museu de Arqueologia e etnologia. N.14, p. 139 - 151, 2004c. 
FINLEY, M. I. A economia antiga. Porto: Afrontamento, 1980. 1983.

Politics in the Ancient world. Cambridge: Cambridge University Press,

FRANCISCATO, C. R. (Trad.). Eurípedes - Héracles. São Paulo: Palas Athenas, 2003.

GARDINER, E. N. Athletics of the Ancient World. Oxford: Clarendon Press, 1971.

GAUQUELIN, M.; LECLERCQ, A.; SILVAN, J. M. Legendes, Mythologies, Histoire et imaginaire sportif. Lille: Centre Lilloi de Recherche en Analyse du Sport, 1995.

GODOY, L. Os Jogos Olímpicos na Grécia Antiga. São Paulo: Nova Alexandria, 1996.

HADOT, P. Que es la filosofia antigua? México: Fondo de Cultura Econômica, 1998.

HANSEN, M. H. Polis and City-State: an Ancient concept and its Modern equivalent. Copenhagen: Acts of the Copenhagen Polis Centre, V.5, 1998.

HART, G. Mitos egípcios. São Paulo: Editora Moraes, 1992.

HARTOG, F. Memórias de Ulisses: narrativas sobre a fronteira na Grécia antiga. Belo Horizonte: Editora UFMG, 2004.

HALICARNASSO, D. Historia antigua de Roma. Madrid: Editorial Gredos, 1984.

HERÓDOTO. História. São Paulo: Ediouro, 2001.

HUIZINGA, J. Homo ludens. London: Routledge \& Kegan Poul, 1955.

JAGUARIBE, H. Um estudo critico da História. São Paulo: Paz e Terra, 2002. v.1. 
JAEGER, W. Paidéia: a formação do homem grego. 4. ed. São Paulo: Martins Fontes, 2003.

JENSEN, Ad. E. Mito y culto entre pueblos primitivos. México: Fondo de Cultura Econômica, 1998.

KANTOROWICZ, E. H. Os dois corpos do Rei. São Paulo: Cia das Letras, 1998.

LAFER, M. C. N. (Trad.) Hesíodo - O Trabalho e os Dias. São Paulo: Iluminuras, 2002.

LANGE, K. Pirâmides, Esfinges e Faraós. Belo Horizonte: Itatiaia, 1964.

LEROI-GOURHAN, A. Préhistorie de l'art occidental. Paris: Mazenod, 1965.

LESKO, L. H. Cosmogonia e cosmologia no Egito Antigo. In: SHAFER, B. E. (org). As religiões no Egito Antigo: deuses, mitos e rituais domésticos. São Paulo: Nova Alexandria, 2002.

LEE, H. M. The Halma: a running or standing jump? In: SCHAUS, G. P.; WENN, S. R. Onward to the Olympics: Historical perspective on the Olympic Games. Waterloo: Wilfrid Laurier University Press, 2003.

LOPEZ, J. Mítologia y Religión egipcias. In: LETE, G. O. Mitologia y Religión del Oriente Antiguo: Egipto y Mesopotamia. Barcelona: Ausa, 1993.

MACHADO, R. P. T. Esporte e religião no imaginário da Grécia Antiga. São Paulo: dissertação de mestrado, EEFEUSP, 2006.

MASSEY, M. Women in Ancient Greece and Rome. Cambridge: Cambridge University Press, 1988.

MAUROMATAKI, M. Greek Mythology and Religion. Athens: Haitalis, 1997.

MAY, P. P. G. Os Mitos Celtas. São Paulo: Angra, 2002.

MENARD, R. Mitologia greco-romana. São Paulo: Opus, 1991a. v.1. 
_. São Paulo: Opus, 1991b. v.2.

São Paulo: Opus, 1991c. v.3.

MENDES, M. O. (Trad.). Odisséia - Homero. São Paulo: Editora da Universidade de São Paulo, 2000.

MUNGUIA, S.S. Los Juegos Olimpicos, educación, deporte, mitologia y fiestas en la Antigua Grecia. Madrid: Anaya, 1992.

NAGEL, L. H. Dançando com os textos Gregos: a intimidade da literatura com a educação. Maringá: EDUEM, 2006.

OliVA, A.; GUERREIRO, M. Pré-Socráticos, a invenção da Filosofia. Campinas: Papirus, 2000.

OTTE, M. La Préhistoire. Paris: De Boeck Université, 2003.

OTTO, W. F. Os deuses da Grécia. São Paulo: Odysseus, 2005.

Teofania. São Paulo: Odysseus, 2006.

PESSANHA, J. A. M. Sócrates. São Paulo: Nova Cultural, 1999.

POLIGNAC, F. La naissance de la cite grecque: cultes, espace et société VIII-VII siécles avant J.-C. Paris: La Découverte, 1984.

PRICE, S. Religions of the Ancient Greeks. New York: Cambridge University Press, 2006.

QUEVAL, I. S'accomplir ou se dépaser: essai sur le sport contemporain. Paris: Gallimard, 2004.

RICOEUR, P. Teoria da Interpretação. Lisboa: Edições 70, 1976.

REESE, A. C.; RICKERSON, I. V. Ancient Greek women athletes. Athens: Ideotheatron, 2000.

RODRIGUES, A. M. (apresentação). Virgilio - A Eneida. Cotia: Ateliê Editorial, Campinas, Editora da Unicamp. 2005. 
RUBIO, K. O Imaginário esportivo: o atleta contemporâneo e o mito do herói. São Paulo: Casa do Psicólogo, 2001.

SCHAUS, G. P.; WENN, S. R. Onward to the Olympics: Historical perspective on the Olympic Games. Waterloo: Wilfrid Laurier University Press, 2003.

SHAFER, B. E. (org). As religiões no Egito Antigo: deuses, mitos e rituais domésticos. São Paulo: Nova Alexandria, 2002.

SILVERMAN, D. P. O divino e as divindades no Antigo Egito. In: SHAFER, B, E. (Org) As religiões no Egito Antigo: deuses, mitos e rituais domésticos. São Paulo: Nova Alexandria, 2002.

SNELL, B. A cultura grega e as origens do pensamento europeu. São Paulo: Perspectiva, 2001.

SOUZA, E. Mitologia I: mistérios e surgimento do mundo. Brasília: UnB, 1988.

SOUZA, J. C. Os pré-socráticos: vida e obra. São Paulo: Nova Cultural, 1999.

THOMAS, J. R.; NELSON, J. N. Métodos de pesquisa em atividade física. Porto Alegre: Artmed, 2002.

THOMPSON, J. B. Ideologia e cultura moderna. Petrópolis: Vozes, 2000.

TORRANO, J. Hesíodo, Teogonia, a origem dos deuses. São Paulo: Iluminuras, 2003.

TOUNY, A. D.; WENIG, S. Sport in Ancient Egypt. Leipzig: Edition Leipzig, 1969.

TUCIDIDES. História da Guerra do Peloponeso. Brasília: Editora Universidade de Brasília, 2001.

VERNANT, J. P. Mito e pensamento entre os Gregos. Rio de Janeiro: Paz e Terra, 1990. 

2000 .

O Universo, os Deuses, os Homens. São Paulo: Companhia das Letras, . Entre Mito e Política. São Paulo: Edusp, 2002.

VERNANT, J. P.; VIDAL-NAQUET, P. Mito e tragédia na Grécia Antiga. São Paulo: Perspectiva, 2008.

VIALOU, D. Images Préhistoriques. p. 63-82, s/d.

Territoires et cultures préhistoriques: fonctions identitaires de l'arte rupestre. In: KERN, A. A. (Org). Sociedades Ibero-Americanas: reflexões e pesquisas recentes. Porto Alegre: EDIPUCRS, 2000.

VIALOU, D; VIALOU, A. V. Modernité cérébrale - Modernité comportamentale de Homo Sapiens. Anthropologie. V. 43, N. 2-3, p. 241-247, 2005.

VIVANTE. B. (Org.) Women's role in ancient civilization: a reference guide. London: Greenwood Press, 1999.

VRETTOS, T. Alexandria: a cidade do pensamento ocidental. São Paulo: Odysseus, 2005.

WATTERSON, B. Women in Ancient Egypt. Gloucestershire: Wrens Park, 1998.

YALOURIS, N. The Olympic Games in Ancient Greece. Athens: Athenon, 2003.

YANGUAS, N. S. Textos para la história antigua de Roma. Madrid: Cátedra, 1977. 